\title{
ASPECTOS COMPORTAMENTAIS DE BOVINOS DA RAÇA ANGUS A PASTO FRENTE À DISPONIBILIDADE DE RECURSOS DE SOMBRA E ÁGUA PARA IMERSÃO
}

\section{Frederico Delbin Glaser}

Dissertação apresentada à Faculdade de Zootecnia e Engenharia de Alimentos da Universidade de São Paulo, como parte dos requisitos para obtenção do Título de Mestre em Zootecnia - Área de concentração: Qualidade e Produtividade Animal.

Orientador: Prof. Dr. Evaldo Antonio Lencioni Titto 


\section{AGRADECIMENTOS}

A DEUS, que me concede inúmeras bênçãos - espero não tê-Lo desapontado;

Aos meus pais, Carlos e Neuza, pela paciência, incentivos e esclarecimentos que fazem de mim uma pessoa melhor a cada dia - este trabalho dedico a vocês;

Aos meus irmãos, Flávio e Felipe (e a Senninha também) pelos momentos de alegria e bom-humor que compartilhamos juntos - amo vocês;

À minha família, pois somos as partes de um todo, especialmente ao meu avô Pedro Delbin Sobrinho, minha tia Selma Delbin, meu tio Johannes Steltenpool, meus primos e primas, e ao saudoso Brigadeiro do $\operatorname{Ar}$ João Jorge B. Glaser;

A minha namorada, Juliana Lucente, pelos momentos incomparáveis que passamos juntos - você é especial;

Ao Professor Doutor Evaldo Antonio Lencioni Titto, por sua orientação, amizade e, acima de tudo, pela confiança em mim depositada;

Ao Professor Doutor Rogério Lacaz-Ruiz, por me mostrar o quanto é importante acreditar - grande parte das minhas virtudes aprendi com você;

Aos Professores Doutores César Gonçalves de Lima, Paulo Roberto Leme, Albino Luchiari Filho, José Bento Sterman Ferraz, José Carlos M. Nogueira Filho, Valdo Rodrigues Herling, Pedro Henrique de Cerqueira Luz, Holmer Savastano Júnior, Joanir Pereira Eler, Alexander Spers, Douglas Emygdio 
de Faria, Roberta Passini e Valter Cromberg pela colaboração e participação com seus conselhos valorosos;

A todos os professores e funcionários da FZEA/USP, pelos ensinamentos e dedicação a esta escola maravilhosa;

Ao amigo Valdomiro Poliselli Júnior, que gentilmente colocou seus animais à disposição para realização do experimento, e aos consultores e funcionários da VPJ Pecuária pelo total empenho e colaboração;

Aos estagiários Guilherme, Fabíola, Mariana e Douglas, pela ajuda e pelos momentos de descontração;

A FZEA e a PCAPS, pela participação na minha formação profissional e realização do experimento;

E finalmente aos meus amigos e amigas (de A a Z): Alan dos Anjos, Alexandre Wakatsuki, André (Vaz e Locatelli), Arlindo Saran, Carlos Utiyama, Daniel Rolnik, Denise Ablas, Éder Pinatti, Felipe Macedo, Fernanda Paiva, Gustavo (Braga, Del Claro, Figueiredo e Taboada), Helena Fagundes, Ivan Formigoni, José Henrique Karsburg, Juliano Jubileu, Karina (Barreto e Gianlorenço), Käthery Brennecke, Luciane Martello, Marcelo van Melis, Maurício Peternelli, Otaviano Carneiro, Ricardo (Abreu e Brumatti), Rick Dalessandro, Roberto Vilhena, Saulo Luz, Wilson Marchesin, e a todos os novos e velhos amigos, pela convivência e por confirmarem (mais uma vez) que a verdadeira amizade não tem preço. 


\section{SUMÁRIO}

RESUMO

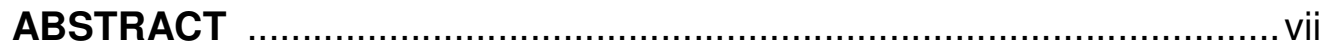

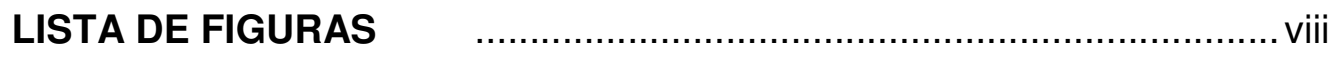

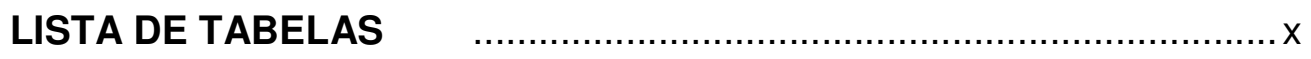

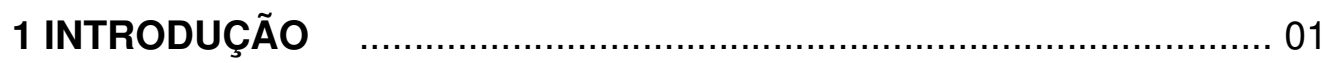

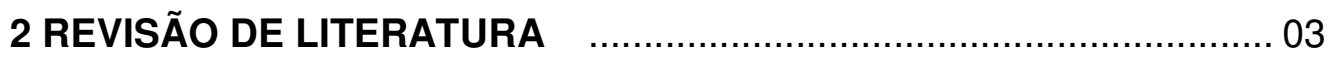

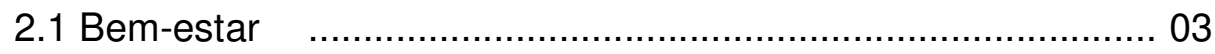

2.2 Estresse e sofrimento .................................................. 06

2.3 Ambiente, clima e adaptação ............................................. 09

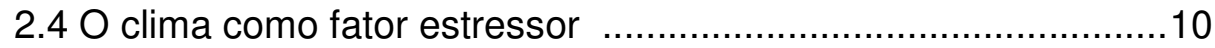

2.4.1 Zona termoneutra e conforto térmico ........................ 11

2.4.1.1 Índices de conforto térmico f....................... 13

2.4.2 Efeitos do clima na termorregulação $\quad$.......................... 14

2.4.3 Efeitos do clima no desempenho $\quad$........................... 17

2.5 A raça Angus $\quad$................................................................. 19

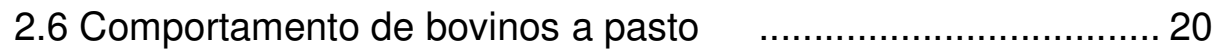

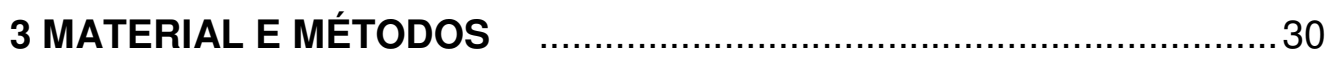

3.1 Tratamentos, animais e condições de manejo $\quad$.....................30

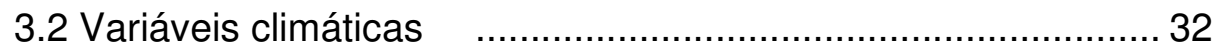

3.3 Comportamento $\quad$................................................ 32

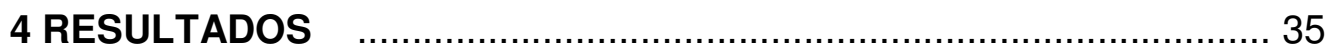

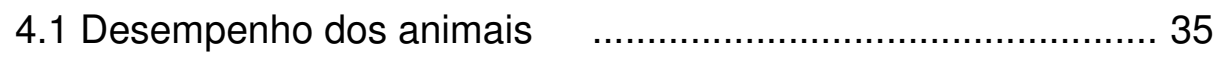

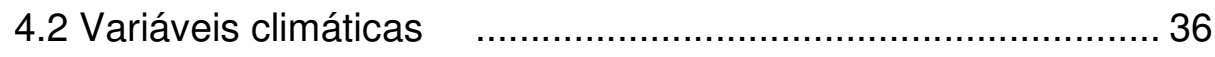

4.3 Comportamento $\quad$................................................. 40

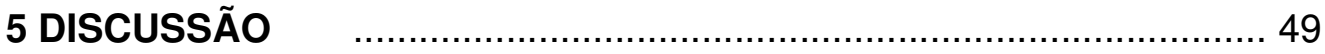

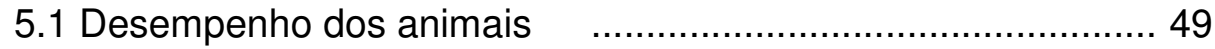

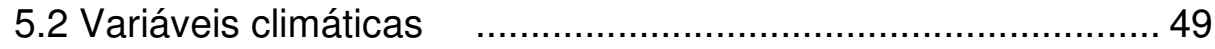

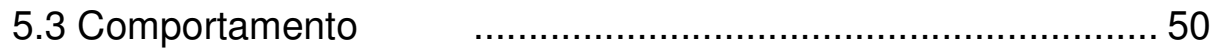




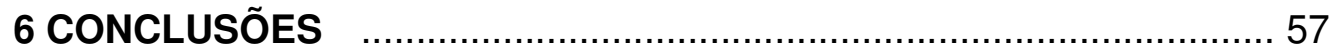

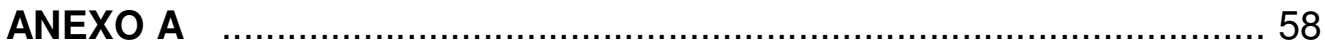

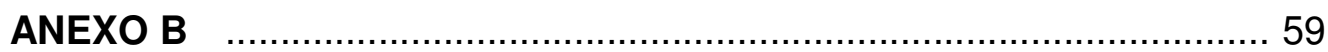

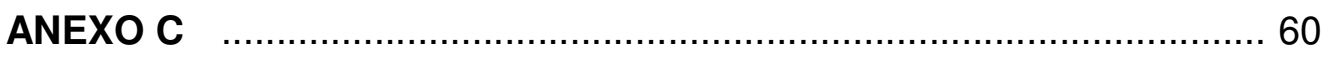

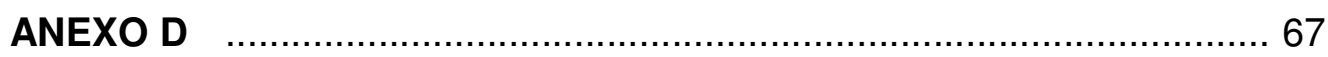

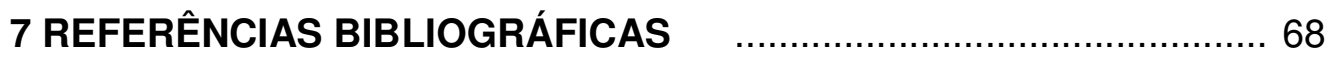




\section{RESUMO}

GLASER, F. D. Aspectos comportamentais de bovinos da raça Angus a pasto frente à disponibilidade de recursos de sombra e água para imersão. 2003, 84p. Dissertação de Mestrado - Faculdade de Zootecnia e Engenharia de Alimentos, Universidade de São Paulo: São Paulo.

Os bovinos mantidos em pastagens de regiões tropicais, incluindo os de origem zebuína, buscam a sombra como recurso de bem-estar térmico nos períodos mais quentes do dia. Neste sentido, o objetivo deste estudo foi avançar no entendimento da utilização de recursos provedores de bem-estar térmico, especialmente quando da utilização de bovinos de origem européia em regiões de clima tropical. Pretendeu-se quantificar a freqüência de utilização dos recursos de sombreamento e de água para imersão, disponibilizados a pasto para touros da raça Angus de pelagem curta e longa, avaliando também as causas e funções dos diferentes comportamentos, detectando as possíveis preferências por água para imersão ou sombra ou interações entre esses recursos. O experimento foi realizado no Campus de Pirassununga da Universidade de São Paulo. Os aspectos comportamentais de oito bovinos machos inteiros da raça Angus (400 Kg de peso vivo e 14 meses de idade) foram avaliados em três diferentes tratamentos: disponibilidade de sombra natural e artificial (TS), disponibilidade de sombra artificial e de água para imersão (TSA), e disponibilidade de água para imersão (TA). A temperatura do ar, a umidade relativa, a radiação solar, a velocidade do ar, e a temperatura de globo negro, foram registradas durante todo o período experimental. A temperatura máxima média do ar foi de $32^{\circ} \mathrm{C}$, com temperaturas de globo negro de $45^{\circ} \mathrm{C}$ ao sol e $37^{\circ} \mathrm{C}$ à sombra. Os maiores registros do índice de temperatura de globo e umidade variaram de 92 a 96 . Os padrões de comportamento foram registrados através de coleta instantânea e contínua, com amostragem pelo método focal a cada 15 minutos, das 8 h00 às 18h00. As variáveis comportamentais observadas foram a posição (ao sol, à sombra ou na água), a postura (em pé ou deitado) e as atividades (pastejo, ruminação, deslocamento, ócio ou outras atividades). Os resultados mostraram que a ocorrência da posição dos animais ao sol diminuiu consideravelmente das $12 \mathrm{~h} 00$ às $14 \mathrm{~h} 00$, para todos os tratamentos. O pastejo foi a principal atividade realizada ao sol, concentrado particularmente nos períodos menos quentes do dia. Quando no tratamento TSA, os animais preferiram utilizar o sombreamento como recurso de defesa contra o calor. O recurso de água para imersão foi utilizado com freqüência das $14 \mathrm{~h} 00$ às $15 \mathrm{~h} 00$ para TSA e das $8 \mathrm{~h} 00$ às $15 \mathrm{~h} 00$ para TA. De maneira geral, observa-se que os animais com menor comprimento de pêlos utilizaram menos os recursos de perda de calor que os animais de pelagem longa. Em condições de pastejo em climas quentes, recursos de defesa contra o calor são essenciais para a melhoria do bem-estar térmico dos bovinos.

Orientador: Prof. Dr. Evaldo Antonio Lencioni Titto

Unitermos: Angus, bem-estar, bovinos, comportamento, pastejo, termorregulação. 


\begin{abstract}
GLASER, F. D. Behavioral patterns of Angus beef cattle under grazing conditions with availability of shade and water for immersion. 2003, 84p. Dissertation of Master Degree - Faculdade de Zootecnia e Engenharia de Alimentos, Universidade de São Paulo: São Paulo.

Cattle, including Bos taurus and Bos indicus, under grazing conditions in tropical areas, seek shade during the hottest periods of the day. The objective of this study was to understand how Angus bulls use the thermal well-being resources, quantifying the frequencies of utilization of shade and water for immersion (pond), available in the pasture, evaluation the causes and functions of different behaviors, detecting the preferences for shade or water for immersion, or interactions of both. The experiment was conducted at the Universidade de São Paulo, Campus of Pirassununga. The behavioral patterns of eight young bulls $(400 \mathrm{Kg}$ live weight, 14 months of age), four with shorter hair length and four with longer hair length ( $>1,30$ $\mathrm{cm}$ ), were evaluated in three different treatments: availability of natural and artificial shade (TS), availability of artificial shade and water for immersion (TSA) and availability of water for immersion (TA). The air temperature, relative humidity, solar radiation, and the black globe temperature were registered for all experimental periods. The average maximum air temperature was $32 \mathrm{C}$ and the black globe value was $45 \mathrm{C}$. The highest value for the black globe-humidity index varied from 92 to 96 . The behavioral patterns were recorded using the focal sampling method, every 15 minutes, from $8 \mathrm{~h} 00$ a.m. to 6 h00 p.m., and the categories observed were the position (in the sun, in the shade or in the water), the posture (standing or lying down) and the activities (grazing, ruminating, moving, resting or other). The results showed that the number of events of animals in the sun were considerably reduced from $12 \mathrm{~h} 00$ a.m. to $2 \mathrm{~h} 00$ p.m., for both treatments. The main activity occurring in the sun was grazing, especially concentrated during the cooler times of the day. When the animals were in the TSA treatment, they preferred to use the shade as a resource against the heat load. The pond was used often from $2 \mathrm{~h} 00$ p.m. to $3 \mathrm{~h} 00$ p.m. (TSA) and from $8 \mathrm{~h} 00$ a.m. to $3 \mathrm{~h} 00$ p.m. for TA. On a whole, the animals with shorter hair length utilized the thermal well-being resources less than the animals with longer hair. Under grazing conditions in hot climates, resources for defense against heat load are essential to improve the wellbeing conditions for cattle.
\end{abstract}

Advisor: Prof. Dr. Evaldo Antonio Lencioni Titto

Key-words: Angus, behavior, cattle, grazing, thermoregulation, welfare. 


\section{LISTA DE FIGURAS}

Figura 1 Visão esquemática dos três piquetes experimentais.

Figura 2 Evolução horária da temperatura do ar (média de cada tratamento). 36

Figura 3 Evolução horária da umidade relativa do ar (média de cada tratamento) 37

Figura 4 Evolução horária da radiação global (média de cada tratamento). 38

Figura 5 Evolução horária da velocidade do ar (média de cada tratamento) ............................................................... 38

Figura 6 Evolução horária da TGN ao sol (média de cada

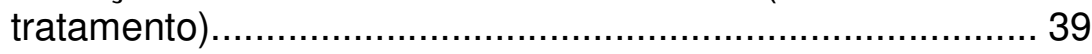

Figura 7 Evolução horária da TGN à sombra (média de cada

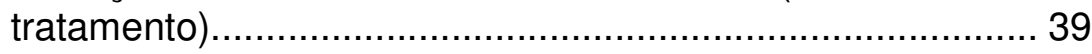

Figura 8 Evolução horária do ITGU (média de cada tratamento)...... 40

Figura 9 Distribuição horária da freqüência de surtos da posição "Ao Sol" (média de cada tratamento).

Figura 10 Distribuição horária da freqüência de surtos da posição "À Sombra" (média de cada tratamento)................................ 42

Figura 11 Distribuição horária da freqüência de surtos da posição "Na Água" (média de cada tratamento).... 43

Figura 12 Distribuição horária da freqüência de surtos da postura "Em Pé" (média de cada tratamento).

Figura 13 Distribuição horária da freqüência de surtos da postura "Deitado" (média de cada tratamento)

Figura 14 Distribuição horária da freqüência de surtos da atividade "Em Pastejo" (média de cada tratamento). 44

Figura 15 Distribuição horária da freqüência de surtos da atividade "Em Ruminação" (média de cada tratamento). 
Figura 16 Distribuição horária da freqüência de surtos da atividade "Em Deslocamento" (média de cada tratamento).... 45

Figura 17 Distribuição horária da freqüência de surtos da atividade "Em Ócio" (média de cada tratamento)....................................... 46

Figura 18 Distribuição horária da freqüência de surtos de "Outras Atividades" (média de cada tratamento)............................... 46

Figura 19 Dendriograma da análise multivariada de conglomerados com ligação completa para o tratamento TS

Figura 20 Dendriograma da análise multivariada de conglomerados com ligação completa para o tratamento TSA.

Figura 21 Dendriograma da análise multivariada de conglomerados com ligação simples para o tratamento TA.

Figura 22 Dendriograma da análise multivariada de conglomerados com ligação completa para os tratamentos TS, TSA e TA........... 48

Figura A Animais utilizando o recurso da sombra artificial.................. 67

Figura B Animais em pastejo matutino.............................................. 67

Figura C Animais em pastejo vespertino............................................. 67

Figura D Animais utilizando o recurso da água para imersão.............. 67 


\section{LISTA DE TABELAS}

Tabela 1 Características individuais de pelagem e peso dos animais do experimento. 35

Tabela 2 Categorias de peso e pelagem.................................. 36

Tabela 3 Correlações entre as temperaturas do ar para os diferentes dias do experimento - valores em vermelho são significativos $(p<0,05)$.

Tabela 4 Correlações entre as umidades relativas do ar para os diferentes dias do experimento - valores em vermelho são significativos $(p<0,05)$

Tabela 5 Correlações entre as radiações globais para os diferentes dias do experimento - valores em vermelho são significativos $(p<0,05)$. 60

Tabela 6 Correlações entre as velocidades do ar para os diferentes dias do experimento - valores em vermelho são significativos $(p<0,05)$ 61

Tabela 7 Correlações entre as temperaturas do globo negro ao sol para os diferentes dias do experimento - valores em vermelho são significativos $(p<0,05)$ 61

Tabela $8 \quad$ Correlações entre as temperaturas do globo negro à sombra para os diferentes dias do experimento - valores em vermelho são significativos $(p<0,05)$.

Tabela 9 Correlações entre os índices de temperatura de globo e umidade para os diferentes dias do experimento - valores em vermelho são significativos $(p<0,05)$. 62

Tabela 10 Séries temporais com distribuição ao acaso $\left({ }^{a}\right)$ pelo teste de Rayleigh, para os diferentes tratamentos.

Tabela 11 Correlações entre os surtos da posição "Ao Sol" para os diferentes animais e tratamentos - valores em vermelho são significativos $(p<0,05)$.

Tabela 12 Amostras temporais significativamente diferentes $(\alpha=0,05)$ para um mesmo animal em diferentes tratamentos. 
Tabela 13 Correlações entre os surtos da posição "À Sombra" para os diferentes animais e tratamentos - valores em vermelho são

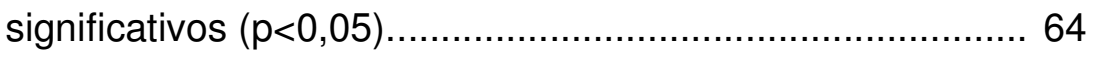

Tabela 14 Correlações entre os surtos da posição "Na Água" para os diferentes animais e tratamentos - valores em vermelho são

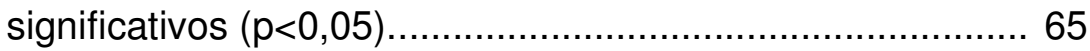

Tabela 15 Média de surtos dos animais nos diferentes tratamentos.....66 66 


\section{INTRODUÇÃO}

Em várias partes do mundo muito se tem discutido a respeito das condições de bem-estar na criação de animais, principalmente porque esses não existem exclusivamente com o propósito de servirem ao homem, seja na forma de trabalho ou alimento. Tais condições derivam da relação existente entre o direito dos animais e os deveres e obrigações morais concernentes aos criadores, técnicos e cientistas. Segundo a Declaração Universal proclamada na assembléia da Unesco em 1978, os animais têm direito à existência, respeito, cura, descanso e proteção, direito a não serem submetidos a atos cruéis ou maltratados e, no caso do animal ser criado para servir como alimento, deve ser nutrido, alojado, transportado e morto sem que para ele resulte ansiedade, angústia ou dor. Atualmente o foco das discussões é referente à Qualidade de Vida oferecida aos animais.

Identificar quais são as condições ótimas do ponto de vista científico, especialmente para decidir o que é melhor ou não para o animal numa criação, é tarefa difícil pois depende essencialmente da observação dos comportamentos resultantes da interação entre fatores biológicos, instintivos, evolutivos, sociais, genéticos e ambientais. A etologia aplicada à produção animal contribui para a adequação e evolução das técnicas de criação e manejo que atendam aos interesses do homem e respeitem as necessidades dos animais, sem prejudicar o meio-ambiente.

Para se criar animais é preciso ter em mente o clima.

O estresse térmico causado pela mudança das funções biológicas acarreta prejuízos no desenvolvimento do animal, na produção de leite e 
carne, e na reprodução, pois o calor é um fator restritivo na produtividade animal em áreas tropicais e áridas. $O$ estresse indica também ausência de bem-estar. Muito têm se estudado sobre as respostas dos animais criados em sistemas intensivos em condições de estresse térmico provocado pelo calor. Contudo, existe pouca discussão na literatura científica considerando situações de manejo extensivo.

Em ambiente aberto, a pasto, a maior parte da incidência solar direta é proveniente da radiação solar, e representa a maior fonte de calor adquirida pelos animais através do ambiente. Uma alternativa para evitar o estresse térmico causado por essa radiação, comum em condições de pastejo, é o uso de sombreamento, que diminui a incidência de radiação direta sobre o animal. Além do sombreamento, o uso de água para imersão favorece a perda de calor pelos bovinos, ajudando-os a manter a temperatura do corpo em níveis térmicos confortáveis, proporcionando bem-estar térmico. Desta maneira, a utilização de técnicas de manejo que proporcionem mudanças ambientais favoráveis é um importante instrumento na melhoria do bem-estar e do desempenho animal.

Assim, o presente trabalho teve como objetivo avaliar o uso do sombreamento e da água para imersão como recursos para perda de calor de bovinos da raça Angus (Bos taurus taurus) a pasto. 


\section{REVISÃO DE LITERATURA}

\subsection{Bem-estar}

No século XVII o filósofo Descartes afirmou: "um animal não é nada além de uma máquina". Ele via apenas o estímulo e a resposta como se as respostas dos animais fossem reações automáticas e necessárias ao estímulo, negando a capacidade dos animais aprenderem e agirem de forma independente e inteligente (Mayr, 1974). Hoje certamente esta afirmação não seria aceita no meio científico ou ético, e seria motivo de pressão pública.

Em verdade, o estudo acadêmico do bem-estar animal não se deu por interesse exclusivamente científico, mas em função também da pressão pública acerca da forma de criação e tratamento aplicada aos animais. e em especial do que esses possam sentir.

É um tanto quanto difícil definir o que é bem-estar para um animal. Segundo Fraser (1999), as tentativas dos cientistas de conceituar o bemestar animal resumem-se em três deduções principais. Assim sendo, para que um animal possa estar incluído dentro do conceito de bem-estar este deve:

a) sentir-se bem, não ser submetido ao medo, à dor ou estados desagradáveis de forma intensa ou prolongada;

b) funcionar bem, no sentido de saúde, crescimento, funcionamento comportamental e fisiológico;

c) levar uma vida natural através do desenvolvimento e do uso de suas adaptações naturais. 
As definições da palavra bem-estar (welfare e well-being), de acordo com o Merriam-Webster Dictionary e com o Cambridge Dictionaries são: "o estado ou condição de estar saudável, feliz, confortável e próspero; felicidade, saúde física ou mental; condição de existência satisfatória ou boa; o estado de sentir-se saudável e feliz; um estado caracterizado pela saúde, felicidade e prosperidade". O dicionário Aurélio define bem-estar como "estado de perfeita satisfação física ou moral, conforto". Avaliar condições como felicidade, saúde mental e satisfação moral em animais é tarefa difícil, pois estas são características subjetivas e intrínsecas aos próprios animais e a ciência ainda não desenvolveu métodos para avaliálas, e parece haver uma sutil divergência no uso da palavra bem-estar. Weary et al. (2000) afirmam que algumas abordagens enfatizam os atributos físicos (crescimento e saúde), mentais (prazer ou sofrimento) e a naturalidade (que reflete a proximidade ou distância do ambiente natural). Lawrence \& Appleby (1996) citam a existência de diversos critérios para determinar o bem-estar, que podem variar desde a sobrevivência básica e crescimento até a redução de doenças e bem-estar psicológico. Broom (1988, 1991) conceitua bem-estar como as respostas do organismo às diversas condições do ambiente, para manutenção da homeostase. Seamer (1998) propõe que o animal está bem quando é bem sucedido no controle ou total eliminação de fatores adversos, através de suas reações comportamentais, fisiológicas e/ou psicológicas e ainda afirma que bemestar significa estar bem, ou seja, o uso do termo bem-estar ruim torna-se inaplicável. Fraser (1997) usa o termo well-being para referir-se às situações inerentes ao próprio animal, ou seja, aos seus estados endógenos e welfare para intervenções humanas feitas para melhorar o well-being. Mas, segundo Barnett \& Hemsworth (1990), todos os critérios estão baseados em demonstrar evidências de mudança. Todos os autores parecem concordar que o bem-estar de um animal depende de sua habilidade de manter sua condição corporal a mais estável possível e evitar sofrimento. 
A definição estabelecida pelo Farm Animal Welfare Council (FAWC), do Parlamento Britânico em seu Código de Bem-estar para Animais de Produção, citada por Webster (1987) e Chevillon (2000), é amplamente aceita e utilizada, e é baseada no reconhecimento das "Cinco Liberdades" inerentes aos animais:

1) A Liberdade Fisiológica - ausência de fome e sede. A alimentação à disposição do animal deve ser suficiente, tanto em quantidade quanto em qualidade, permitindo crescimento, vigor e saúde normais;

2) A Liberdade Ambiental - ausência de desconforto térmico ou físico. As instalações e/ou edificações devem ser adaptadas, fazendo com que o ambiente não seja excessivamente quente ou excessivamente frio, nem impeça o descanso e atividades normais;

3) A Liberdade Sanitária - ausência de injúrias e doenças. As instalações devem apresentar-se de forma a minimizar o risco de doenças, fraturas e machucados, e quaisquer casos que ocorram devem ser reconhecidos e tratados sem demora;

4) A Liberdade Comportamental - possibilidade para expressar padrões de comportamento normais. $\mathrm{O}$ ambiente deve permitir e oferecer condições para que o animal expresse seus instintos e comportamentos normais, inerentes à sua espécie.

5) A Liberdade Psicológica - ausência de medo e ansiedade. $O$ animal não deve ser exposto a situações que the provoquem angústia, ansiedade, medo ou dor.

Esses cinco itens procuram oferecer uma abordagem para a compreensão do bem-estar como ele é percebido pelo próprio animal (e não como definido por seu criador ou mesmo pelo consumidor) e servem como um ponto de partida para avaliar os aspectos bons e ruins de um sistema de criação (Webster, 1987).

Existem muitos indicadores do bem-estar, que variam de acordo com a espécie estudada. Ao tentar definir o que é um ambiente provedor de bem-estar para um animal, há um consenso acerca da colocação de Appleby \& Hughes (1997), que afirmam que um ambiente é apropriado 
quando permite ao animal satisfazer suas necessidades incluindo recursos próprios e ações cuja função é atingir um objetivo. Em um dado momento da sua vida, o animal terá uma série de necessidades, algumas mais urgentes que outras, mas cada uma delas terá uma conseqüência no seu estado geral (Baxter, 1988; Broom \& Johnson, 1993). Se um animal não está apto a satisfazer uma necessidade, a conseqüência, mesmo que rápida e eventual, será um prejuízo no bem-estar (Fraser \& Broom, 1990).

Webster (2001) salienta que a qualidade de vida se torna inaceitável quando o animal fica sem esperança, ou seja, quando o animal não pode realizar alguma atividade que possa contribuir de maneira construtiva para a existência do bem-estar.

Broom \& Johnson (1993) destacam três idéias relativas ao bem-estar dos animais:

1) Bem-estar é uma característica do animal, não é algo que pode ser fornecido a ele. A ação humana pode alterar com o objetivo de melhorar o bem-estar animal, mas não se refere como bem-estar o ato de proporcionar um recurso ou condição;

2) Bem-estar pode variar entre muito ruim e muito bom. Não se pode simplesmente pensar em preservar e garantir o bem-estar, mas sim em melhorá-lo ou assegurar que ele é bom.

3) Bem-estar pode ser medido cientificamente, independentemente de considerações morais. A sua medida e interpretação deve ser objetiva.

Outra forma de entender o bem-estar seria abordar conceitos distintos e até mesmo contrários. Descrever os estudos sobre estresse e sofrimento talvez auxiliem na melhor compreensão do que significa bemestar.

\subsection{Estresse e sofrimento}

Existem diversas abordagens para identificar a existência do bemestar animal. O indicador mais apropriado do bem-estar seria a ausência de estresse e de sofrimento. 
Muitas vezes, os padrões de comportamento são reflexos das tentativas do animal de se libertar ou escapar de agentes/estímulos estressantes. Essas reações podem ser usadas para identificar e avaliar o estresse e por oposição, o bem-estar.

$\mathrm{Na}$ prática da etologia, o bem-estar é avaliado por meio de características fisiológicas e comportamentais. As medidas fisiológicas são associadas ao estresse e baseadas no fato de que, se o estresse aumenta, o bem-estar diminui; já os indicadores comportamentais estão relacionados especialmente à ocorrência de reações e comportamentos anormais ou que se afastem dos que ocorrem no ambiente natural.

Selye (1936), definiu estresse como sendo o estado do organismo que, após a atuação de agentes de quaisquer naturezas, responde com uma série de reações não específicas de adaptação.

Segundo Fraser et al. (1975), um animal está em estado de estresse quando necessita alterar de maneira extrema sua fisiologia ou comportamento para adaptar-se a aspectos adversos do seu ambiente e manejo. Essa adaptação envolve uma série de respostas neuroendócrinas, fisiológicas e comportamentais que funcionam para manter o equilíbrio de suas funções (Barnett \& Hemsworth, 1990; Von Borrel, 1995). De acordo com Von Borrel (1995), o estresse é um termo geral que implica em uma ameaça à qual o corpo precisa se ajustar.

A todo fator exógeno provedor de estresse, denomina-se fator estressor: calor, frio, umidade, fome, sede, infecções, parasitas, injúrias físicas, ambiente inadequado, dor, elevada densidade populacional, isolamento, situações que levam ao medo e/ou ansiedade, entre outros.

Huntingford (1984) diz que uma das potenciais aplicações das pesquisas etológicas é identificar e quantificar os sinais de sofrimento dos animais criados e explorados pelo homem e determinar as condições que induzam a esse estado, encontrando meios para reduzir ou remover tal situação.

Os animais freqüentemente apresentam inúmeras mudanças fisiológicas quando expostos a uma série de situações nocivas, desde a 
possibilidade de agressão física até exposições prolongadas a condições adversas. Segundo Huntingford (1984), estas mudanças ocasionam um aumento na atividade autônoma e na produção de hormônios, que são ditas resultantes do estresse. Uma vez que estas respostas fisiológicas apresentem-se em situações onde, potencial ou efetivamente, o animal ou a integridade de suas funções esteja em perigo, é razoável supor que algo o esteja desagradando e poder-se-ia assim, proporcionar uma maneira de detectar o quanto o animal está sofrendo. Contudo, muitas técnicas para detecção destas mudanças são um tanto quanto invasivas, muito caras e impraticáveis dependendo da espécie, do número de animais em questão etc; além do fato de que tais reações podem significar que as defesas e a própria saúde do animal estão funcionando bem. Fraser \& Broom (1990) reportam que várias formas de privação, desconforto ou dor são indicadores de um bem-estar ruim, assim como a redução na habilidade de crescer e se reproduzir, lesões no corpo e doenças, menor expectativa de vida, problemas no sistema imunológico, reações fisiológicas e comportamentais para o controle homeostático. Segundo Paranhos da Costa \& Cromberg (1997), identificar, medir e analisar as condições em que o bem-estar é ruim é mais fácil do que quando ele é bom.

Torna-se cada vez mais importante observar o que ocorre com o animal em condições naturais; os sinais de angústia estão correlacionados com os sinais fisiológicos do estresse e a observação do comportamento pode servir como substituto de técnicas mais complexas. Existem evidências que animais, incluindo espécies domesticadas, tomam decisões sobre quando, onde e o que devem comer para manter boa sua saúde e condição corporal, mostrando preferências sensatas (Huntingford, 1984). Segundo McFarland (1999), muitos animais são capazes de aprender como obter substâncias essenciais, sendo hábeis também em aprender qual alimento os faz sentir melhor.

Para os animais, o sofrimento e a dor são estados aversivos e, portanto, evitarão condições em que sofram, optando por fazer escolhas que sejam benéficas a eles. 


\subsection{Ambiente, clima e adaptação}

A existência de um organismo, seja qual for sua espécie, é conseqüência de uma série de ações e reações da natureza em dado momento, ocasionando novas interações, seja com o ambiente, com outros da sua espécie ou mesmo com espécies diferentes. O ambiente, e particularmente o clima são importantes fatores que podem afetar tais interações.

Head (1995), diz que o ambiente compreende todos os fatores físicos, químicos e biológicos que circundam o corpo do animal, e inclui fatores relativos à temperatura e luz, fatores que provoquem mudanças de comportamento e que causem doenças, entre outros, variando com o passar do tempo e da localidade.

$O$ ambiente pode ser definido como o conjunto de tudo o que afeta a constituição, o comportamento e a evolução de um organismo, e que não envolve diretamente fatores genéticos (Silva, 2000); assim, pode-se dizer que o ambiente é responsável pela maior parte da interferência existente nas condições de vida de um organismo (diga-se de um animal, no presente trabalho).

O clima, segundo o dicionário Aurélio, é o conjunto de condições meteorológicas (temperatura, pressão e ventos, umidade e chuvas) características do estado médio da atmosfera em um ponto da superfície terrestre, e é formado por fatores e elementos climáticos que são produzidos e alterados por diversos eventos meteorológicos, geográficos e astronômicos (Baccari, 2001).

O clima, o ambiente e a capacidade de adaptação influenciam o comportamento dos animais. Segundo Silva (2000), existem dois pontos de vista para a conceituação do termo adaptação. O primeiro é genético, e define adaptação como sendo o conjunto de alterações nas características herdáveis, que favorecem a sobrevivência de uma população de indivíduos em um determinado ambiente. O segundo é biológico, resultado da ação conjunta de características morfológicas, anatômicas, fisiológicas, 
bioquímicas e comportamentais, no sentido de favorecer a sobrevivência e promover o bem-estar de um organismo em um ambiente específico. Assim, quanto mais adaptado o organismo, em termos genéticos e biológicos, maiores serão suas chances de desenvolver todo seu potencial em determinada situação ambiental e climática.

Paranhos da Costa (2000) comenta que, no dia-a-dia da fazenda os bovinos invariavelmente enfrentam situações que causam desconforto: temperatura, radiação solar, insetos e parasitas. Tais condições podem, em conjunto ou isoladamente, levar os animais ao estresse. Durante grande parte de suas vidas os animais fazem escolhas baseadas na avaliação do ambiente e em suas próprias necessidades; dentro da limitação proveniente dos genes, os animais adaptam suas reações fisiológicas e comportamentais e seu metabolismo para apresentar respostas adequadas às diversas características e condições do ambiente, na busca da condição/opção que o beneficie da melhor maneira. Para que isso ocorra, o ambiente precisa oferecer os recursos necessários para a ocorrência dessas respostas, sob pena de ocorrer estresse, decorrente da falha na adaptação do animal ao meio (Broom \& Johnson, 1993).

\subsection{0 clima como fator estressor}

Existe uma estreita relação entre a distribuição dos animais pelas diferentes áreas geográficas e as condições climáticas. Isso pode ser explicado pelas grandes diferenças de temperatura do ambiente entre essas áreas (Santos, 1999). Em ambientes com altas temperaturas, a radiação solar direta e indireta, a velocidade do vento e a umidade são os principais fatores estressores para os animais (Blackshaw \& Blackshaw, 1994; Silanikove, 2000).

De acordo com Nããs (1989), os fatores climáticos mais significativos são: a radiação solar, a influência da longitude e da latitude, a influência da altitude e da umidade relativa do ar, enquanto os elementos climáticos mais expressivos são: a temperatura do ar, a umidade relativa do ar, a radiação 
solar, o grau de nebulosidade, os ventos e a pluviosidade. Todos estes componentes atuam de maneira simultânea no ambiente, e por conseqüência, nos animais. O clima parece ser o fator de maior relevância quando se pretende criar animais, pois age diretamente sobre o animal e não sobre a possibilidade de sua exploração, sendo limitante na maioria das vezes (Santos, 1999).

\subsubsection{Zona termoneutra e conforto térmico}

Os bovinos são animais capazes de manter a estabilidade fisiológica do seu corpo. Esta capacidade refere-se aos mecanismos de autoregulação e controle dos estados químicos e funcionais internos do organismo frente às flutuações do ambiente externo (McFarland, 1999). Esse equilíbrio dinâmico é denominado homeostase, sendo esta uma importante função para que a espécie possa viver em condições ambientais variadas.

A termorregulação refere-se especificamente à capacidade do animal em manter a temperatura corporal estável. A habilidade de regular a temperatura interna é uma adaptação evolutiva que permite aos animais homeotermos minimizar problemas provenientes da variação da temperatura ambiente (Silanikove, 2000), pois suas taxas metabólicas criam uma fonte interna de calor, além de possuírem estruturas isolantes na superfície corporal que previnem a dissipação descontrolada de calor (McFarland, 1999). McFarland (1999) acrescenta que os mamíferos mantêm a temperatura do corpo sutilmente acima da temperatura que o envolve.

Apesar da grande capacidade dos mamíferos em manter sua temperatura estável, há situações onde a necessidade de perda de calor não ocorre de maneira satisfatória, ocasionando a ação de outros mecanismos para que a dissipação desse calor aconteça. A alteração funcional e a reação ocorrem num mesmo sentido, o que aumenta o desequilíbrio (Titto, 1998). É o chamado feedback positivo. No caso da 
temperatura corporal, isso pode ocorrer caso as condições do ambiente não forneçam alternativas eficientes para trocas térmicas, exigindo um esforço cada vez maior por parte do animal. $O$ aumento excessivo da temperatura corporal devido às condições ambientais adversas, como no caso de climas tropicais e sub-tropicais, ocasiona um aumento de reações metabólicas que, por conseqüência, liberam mais calor nos tecidos, elevando a temperatura interna.

A zona termoneutra é a faixa de temperatura ambiente efetiva na qual o animal não sofre estresse por frio nem por calor. Dentre os limites da ZTN $^{1}$, o animal mantém uma variação normal da temperatura corporal e da freqüência respiratória, sendo que o apetite é normal e a produção é ótima, e o gasto de energia para a mantença do animal é mínimo e constante, maximizando a retenção de energia da dieta (Baccari, 2001). Desse modo, a energia do organismo pode ser utilizada para os processos produtivos, não havendo desvio excessivo de energia para manter o equilíbrio fisiológico (Baccari et al., 1984). As temperaturas ambientais críticas mínima (ou inferior) e máxima (ou superior) definem os limites da ZTN (Robertshaw, 1981). Não existe uma unanimidade entre autores no que se refere aos limites da ZTN, uma vez que diferentes fatores podem influenciar a determinação dos pontos exatos (temperaturas críticas inferior e superior). Como exemplo, a maior velocidade do vento pode ampliar essa zona além da temperatura crítica superior, e o aumento da radiação solar e umidade podem diminuir a zona de conforto, baixando a temperatura crítica superior (Ablas, 2002).

A subdivisão da ZTN em uma zona de bem-estar térmico, como para humanos, facilita a descrição da relação entre o animal e o ambiente, do ponto de vista da termoneutralidade. Em humanos, o termo original utilizado foi conforto térmico. Contudo, o termo conforto implica reconhecimento cognitivo, enquanto a decisão em relação à condição do animal depende daqueles que cuidam dele (Silanikove, 2000). Assim, prefere-se utilizar o termo bem-estar térmico para descrever o estado do

\footnotetext{
${ }^{1}$ Zona Termoneutra
} 
animal em relação ao ambiente em que ele se encontra (Ablas, 2002, citando Hafez, 1973 e Silanikove, 2000).

\subsubsection{1 Índices de conforto térmico}

As conseqüências causadas pelo impacto do ambiente são alteradas pelos diferentes comportamentos do animal, podendo diferir nas espécies, raças e indivíduos, assim como a suscetibilidade a outros tipos de estresse pode realçar os efeitos do estresse térmico (Silanikove, 2000). Essas considerações enfatizam a natureza problemática de se estabelecer uma relação útil entre índices de estresse térmico e bem-estar versus produtividade, particularmente em sistemas extensivos (Ablas, 2002). Segundo Buffington et al. (1981), o índice mais comum existente é o Índice de Temperatura e Umidade (ITU), adotado pela United States Weather Bureau como índice térmico para humanos, e posteriormente para vacas leiteiras. O ITU utiliza-se da temperatura do ar e da temperatura de ponto de orvalho em sua fórmula, não levando em consideração fatores ambientais importantes como a radiação solar e a movimentação do ar. Considerando isso, Buffington et al. (1981) propuseram uma modificação do ITU, que denominaram Índice de Temperatura de Globo e Umidade (ITGU), fornecendo um índice adimensional, e fornecendo um dos melhores índices para representar o estresse térmico em áreas abertas, sob radiação térmica direta (global) e indireta (difusa), segundo Ablas (2002). Buffington et al. (1981) e Silva (2000) afirmam que o ITGU é mais preciso para predizer o bem-estar térmico em regiões tropicais pois, seu cálculo incorpora a umidade através da temperatura do ponto de orvalho, a temperatura de bulbo seco e radiação solar, em um único valor.

O índice pode ser calculado pela seguinte equação: 


\section{$I T G U=T_{g n}+0,36 T_{p o}+41,5$}

Onde:

$$
\begin{aligned}
& \mathbf{T}_{\mathrm{gn}}=\text { Temperatura de Globo Negro ao Sol, }\left({ }^{\circ} \mathrm{C}\right) ; \\
& \mathbf{T}_{\mathbf{p o}}=\text { Temperatura do Ponto de Orvalho, }\left({ }^{\circ} \mathrm{C}\right) .
\end{aligned}
$$

Tais índices são utilizados na avaliação das situações climáticas que afetam a regulação do organismo e o desempenho animal.

\subsubsection{Efeitos do clima na termorregulação}

Quando a temperatura externa extrapola os limites fisiológicos (temperaturas críticas inferior e superior) e o animal começa a ganhar calor, logo aciona vários mecanismos para promover a perda de calor e voltar ao equilíbrio térmico (Santos, 1999).

Em sua maioria, as alterações efetuadas por um animal envolvem a dissipação do calor para o ambiente e a redução da produção do calor metabólico (Titto, 1998; Silanikove, 1992, 2000).

As principais vias para a perda de calor do corpo são (Berman et al., 1985; Nããs, 1989; Titto, 1998, McFarland, 1999; Santos, 1999):

1) Condução: ocorre pela transferência de calor pelo contato direto, através de superfícies de substâncias sólidas e/ou líquidas, entre regiões com temperaturas diferentes. Pode ocorrer entre tecidos ou entre o corpo e um objeto externo, como o chão ou a água. A condução do calor pode ser reduzida pelo isolamento ocasionado por camadas de gordura do corpo e pela camada de ar contida na pelagem da superfície corporal. A temperatura faz-se sentir sobre os animais, através da condução.

2) Convecção: a perda de calor ocorre como resultado da circulação do sangue aquecido vindo do interior do corpo para os tecidos mais frios da superfície, potencializada principalmente pela passagem de ar frio através da pelagem do animal. 
3) Radiação: é a forma de troca de calor que ocorre no vácuo. Dessa maneira, os animais ganham e perdem calor por radiação, dependendo da diferença de temperatura existente entre o animal e todo o ambiente que o envolve.

4) Evaporação: a evaporação de água de áreas úmidas da superfície corporal do animal propicia perda de calor.

5) Expiração: a perda de calor ocorre quando, ao respirar, o animal expira o ar mais aquecido do que quando foi inspirado. Por perderem muita água através da respiração, os animais tendem a usar esse recurso somente em situações emergenciais, apesar dos bovinos o utilizarem com freqüência.

As principais reações homeostásticas contra o estresse térmico em mamíferos incluem o aumento das taxas respiratórias e de sudação, redução do ritmo cardíaco e da ingestão de alimentos (Silanikove, 2000). Segundo Santos (1999), a alta temperatura aumenta o fluxo sanguíneo na superfície do corpo, levando ao aumento da sudorese e da dissipação do calor pela evaporação.

De maneira geral, o animal perde calor por condução, convecção, radiação, evaporação da água e expirando o ar. No entanto, as perdas por radiação e convecção só são realçadas em ambientes com temperaturas menores (Silanikove, 2000).

Blackshaw \& Blackshaw (1994) complementam que em ambientes com altas temperaturas, as perdas evaporativas são os principais mecanismos para a dissipação de calor em bovinos.

O estresse térmico depende da produção interna de calor e de fatores que influem nas trocas térmicas, que por sua vez dependem dos gradientes de temperatura e pressão de vapor existentes entre o animal e o ambiente. Silanikove (2000) reporta que o equilíbrio da temperatura corporal é mantido em níveis relativamente constantes, pois existe um balanço entre a produção e a perda de calor. Os fatores que aumentam a produção de calor corporal incluem exercícios, o ato de tremer, tensões imperceptíveis da musculatura, aumento do metabolismo químico, doenças 
(febre), e o aumento do calor externo; entre os fatores que aumentam a perda de calor está a mudança interna na distribuição de sangue, diminuição da condutância dos tecidos, realçada pela sudação, salivação, vasodilatação periférica, camada mais curta de isolamento (pêlos), ambiente mais frio, entre outros.

Através da pele o animal absorve calor na forma de energia radiante ou através de convecção ou condução, quando a temperatura do ambiente está acima da temperatura da pele; contudo, Findlay (1950) afirma que a pele dos bovinos é um importante meio para a dissipação de calor por condução, radiação e por evaporação da água. A perda de calor através da pele depende em parte do gradiente de temperatura entre esta e o ar, objetos sólidos ou líquidos; perdas por vias não evaporativas tendem a diminuir quando a temperatura ambiente sobe, tornando o animal dependente da vasodilatação periférica e da evaporação de água para reforçar a perda de calor e prevenir o aumento da temperatura corporal (Berman et al., 1985). A alta temperatura provoca a dilatação dos vasos sanguíneos e o aumento do fluxo na superfície do corpo, levando à elevação da sudorese e da dissipação de calor pela evaporação, aumentando a necessidade de água para o organismo.

Com o aumento da umidade relativa, diminui a dissipação de calor pela pele por perda na difusão de água (Findlay, 1950; Hafez, 1973; Titto et al., 1998). Se a temperatura do ar aumentar (e o ar continuar úmido), a perda de calor decrescerá até que o animal passe a receber calor do meioambiente, especialmente se estiver sob a ação direta da radiação solar. Findlay (1950), acrescenta ainda que a carga de energia radiante incidente no animal, em regiões tropicais, pode ser maior que três vezes o total de calor endógeno produzido pelo próprio animal.

A coloração da pelagem dos bovinos é um importante mediador do impacto da radiação solar, pois afeta a troca de calor por convecção e evaporação do suor (Blackshaw \& Blackshaw, 1994). Essa coloração faz pouca diferença na perda de calor, mas afeta o ganho de calor por radiação (McFarland, 1999). 
As características físicas da pelagem podem afetar o ganho ou perda de calor não-evaporativo (Yousef, 1985; McFarland, 1999).

McFarland (1999) ressalta que, a pelagem molhada aumenta a perda de calor por condução e que alguns animais incrementam a perda de calor evaporativo umedecendo a superfície corporal com saliva ou molhando-se com água, o que corrobora as conclusões de Titto et al. (1996) em trabalho que utilizou banhos de água sobre a superfície corporal de bubalinos. Esse fato confere à pele e pelagem uma grande importância como meio essencial de dissipação de calor endógeno.

A tolerância ao calor varia de acordo com as espécies, com as raças e dentro das raças. A adaptação do animal, ou o fato de possuir uma tolerância ao calor elevada, permite uma melhor resposta termorregulatória, facilitando a manutenção do equilíbrio homeotérmico (Santos, 1999; Ablas 2002). Entretanto, meios para dissipação de calor podem ser colocados à disposição dos animais, com o intuito de melhorar as condições térmicas externas e conseqüentemente beneficiar o equilíbrio da temperatura interna por parte do animal (Titto, 1998).

\subsubsection{Efeitos do clima no desempenho}

O calor é o maior limitante da produtividade dos animais em zonas tropicais e áridas, segundo Silanikove $(1992,2000)$. O estresse por calor é um dos principais limitantes na produção de bovídeos nos trópicos, devido às mudanças drásticas que ocorrem nas funções biológicas do animal (Ablas, 2002). Alterações nas condições ambientais podem causar uma redução significativa dos processos de crescimento e reprodução animal.

As altas temperaturas do ar, principalmente quando associadas a altas umidades relativas e radiação solar intensa são causas de redução na produção de leite de vacas de alta e mesmo moderada produção. A radiação solar incidente sobre vacas, quando da ausência de sombra nas horas mais quentes do dia no verão tropical, pode tornar-se um forte estressor, reduzindo a produção (Titto, 1998). 
O ganho de peso também pode ser afetado pelas condições climáticas adversas (Santos, 1999) ocasionando perdas na produção e produtividade individual de cada animal, e por conseqüência de todo o rebanho.

Perdas significativas nos índices reprodutivos de novilhas e vacas são ocasionadas pela alta temperatura ambiental (Thatcher et al; 1974, Thatcher \& Collier, 1982).

Huntingford (1984) ressalta que, além de perdas na produção, a saúde dos animais pode ser afetada por condições que acarretam desconforto.

O resultado final de todas essas mudanças será a limitação do crescimento, da produção e da reprodução (Findlay, 1950; Albright \& Alliston, 1972; Bianca, 1973; Baccari et al., 1984, 1998; Finch, 1984; Yousef, 1985; Igono et al., 1992; Jacobsen, 1996; Marai \& Habeeb, 1998; Titto, 1998; Silanikove, 1992, 2000).

Em ambientes de clima quente, duas estratégias podem ser utilizadas para aumentar o desempenho animal: a primeira é utilizar raças que sejam geneticamente adaptadas ao ambiente local; a segunda é alterar o ambiente a fim de reduzir o estresse térmico pelo calor (Hansen \& Aréchiga, 1999).

Desta maneira, para que existam condições de bem-estar, dois contextos devem ser observados: quando o animal não consegue manter a homeostase e quando consegue as custas de muito esforço. Paranhos da Costa \& Cromberg (1997) reportam que os animais possuem sistemas funcionais de controle, que atuam na tentativa de manter o equilíbrio de funções como a temperatura corporal; e quando estimulados, acionam esses sistemas na tentativa de encontrar recursos para manutenção do equilíbrio. Tais sistemas conduzem a diferentes comportamentos, que são necessários para entender como cada espécie ou raça responde às condições ambientais, definindo seu grau de susceptibilidade a situações potencialmente redutoras do bem estar, e conseqüentemente da produção. 


\subsection{A raça Angus}

A raça Aberdeen-Angus é originária de um grupo relacionado às raças mochas locais do nordeste e centro da Escócia, em um clima que exigia animais vigorosos (Fraser, 1959; Willians, 1967; Felius, 1985).

Segundo Santiago (1975), os criadores Hugh Watson, da região de Angus, e William McCombie, do condado de Aberdeen, empenharam-se na formação da raça, que por esse fato recebeu a denominação Aberdeen Angus, também conhecida como Polled Angus, ou Black Polled. A raça foi reconhecida oficialmente em 1835.

As principais características dessa sub-espécie (Bos taurus taurus) são: a baixa mortalidade dos bezerros, facilidade de parto (fato esse devido tanto à habilidade materna quanto ao baixo peso ao nascer do bezerro/a), o fator genético dominante para a ausência de chifres, alta conversão alimentar, precocidade sexual, crescimento acelerado (grande velocidade de ganho de peso), longevidade, docilidade, adaptabilidade a uma ampla gama de climas e condições ambientais, altos níveis de fertilidade, a produção de leite das vacas, e especialmente, a habilidade de transmitir carcaças de qualidade superior, pois é a raça com o maior desenvolvimento para qualidade de carcaça (Fraser, 1959; Santos, 1999), sendo muito apreciada na utilização em cruzamentos (Santiago, 1975; Santos, 1999).

A conformação geral da raça é especialmente representada por animais de corpo cilíndrico, profundo e compacto, com pêlos de comprimento curto a longo, existindo animais com pelagem negra ou vermelha (que deu margem à formação de uma variedade dessa cor, sendo essa a única diferença existente em relação ao gado negro), segundo reportam Fraser (1959), Willians (1967), Santiago (1975), Felius (1985) e Santos (1999). Esta variedade é também conhecida como Red Aberdeen Angus, ou simplesmente Red Angus, e foi especialmente trabalhada por criadores dos estados do Texas e Oklahoma, nos Estados 
Unidos, onde foi estabelecida a Associação de Red Angus em 1954 (Felius, 1985).

Atualmente a raça está presente nos países de vanguarda onde a carne bovina é produzida (Fraser, 1959; Santos, 1999). São bons pastadores e suportam bem o calor, afirma Willians (1967).

Para Santiago (1975) a raça Angus adapta-se exclusivamente às regiões clima temperado, e afirma que em experimentos realizados no Estado de São Paulo, demonstrou-se à inconveniência de sua exploração em zonas de clima subtropical e tropical.

Segundo Santos (1999), o desenvolvimento de novas tecnologias sempre leva em conta as virtudes da raça Angus, pois é tida como uma raça-base da moderna pecuária mundial; ou seja, a raça apresenta certas virtudes que se tornam cada vez mais importantes, tais como o baixo peso ao nascer, a habilidade de se adaptar a climas tropicais, a qualidade da carne e a facilidade de produzir animais precoces.

\subsection{Comportamento de bovinos a pasto}

A observação do comportamento animal (especialmente em condições livres, ou ao menos próximas das encontradas em seus habitats naturais) fornece uma ampla de informações necessárias para o real entendimento de como os animais devem ser manejados em sistemas de produção.

Entende-se por atividade livre, o comportamento de um animal quando deixa de estar submetido à vigilância humana, tendo a liberdade de seguir seus próprios instintos. O bovino criado a pasto continua sobre a influência do homem pois, esse é quem determina o local, e por conseqüência, o alimento, a água e o espaço que estão disponíveis ao animal; contudo seu comportamento pode ser considerado livre em tais condições (Lee, 1954); buscando a menor interferência ou limitação possível na expressão do comportamento natural dos bovinos, facilitando a adaptação desses aos sistemas de criação e estabelecendo avanços na 
interação entre humanos e bovinos, mesmo em condições que resultem em estresse aos animais, como no caso das vacinações (Paranhos da Costa, 2000).

Ao possibilitar tal liberdade aos animais, mesmo que em um pasto cercado, os bovinos são motivados a explorar e investigar o novo local. Esse comportamento exploratório consiste em qualquer ação que forneça novas informações sobre o ambiente. Os bovinos exploram todo novo pasto/piquete onde são colocados e prestam atenção inicialmente aos limites do local, seguindo as cercas antes de explorar o interior do cercado. Fontes de água para ingestão são importantes locais a serem encontrados. Em piquetes pequenos que permitam uma visão ampla, o grupo se dispersa rapidamente adotando o espaçamento característico do pastejo; por outro lado, em grandes pastos, dias ou semanas podem transcorrer antes que uma parte do local seja explorada por todo o grupo (Fraser \& Broom, 1997); sendo que os bovinos geralmente aprendem com facilidade quando o alimento e a água são colocados em locais diferentes dos habituais.

Segundo Fraser \& Broom (1997), o ato de buscar alimento envolve uma série de comportamentos e estímulos, e refere-se às atividades dos animais quando estão se movendo de tal maneira a encontrar ou adquirir o alimento (no caso, o capim).

O termo pastejo refere-se ao ato de comer a planta forrageira fresca no campo/pasto (Hafez, 1973; Voisin, 1974; Paranhos da Costa, 2000).

No caso dos hábitos de pastejo de bovinos, o comportamento ingestivo refere-se à seqüência de eventos que levam à ingestão da planta forrageira (ou água/mineral), e varia em função de fatores nutricionais e não-nutricionais. Os fatores nutricionais incluem o preenchimento do rúmem, nível de ácido acético ruminal, demanda por nutrientes, entre outras, provocando respostas do sistema nervoso central através de vários estímulos integrados no cérebro, resultando no início e término da alimentação (Curtis \& Houpt, 1983). 
Segundo Poppi et. al. (1987), além dos fatores nutricionais, os fatores não-nutricionais são importantes determinantes na ingestão, modificando a atividade de pastejo. Estes fatores são influenciados essencialmente pela estrutura do pasto e pelo comportamento dos animais. Os autores ressaltam que os bovinos utilizam os sentidos (visão, paladar, olfato e tato) para avaliar o esforço envolvido na atividade de pastejo, e se esse esforço é muito grande, a ingestão é limitada a níveis abaixo da demanda por nutrientes, salientando que a ingestão por bocado diminui com a redução na disponibilidade de pasto - quantidade e qualidade da planta forrageira - e o aumento no tempo de pastejo geralmente é insuficiente para manter a atividade de ingestão, até que o ato impertinente na captura/recolhimento do capim ocasiona o cessar do pastejo.

Os bovinos são animais gregários (Paranhos da Costa, 2000), ou seja, vivem em grupo, e embora a vida em grupo traga uma série de vantagens adaptativas (como a defesa contra predadores) ela também traz o aumento na competição por recursos, principalmente quando escassos. Como exemplo, quando um animal se alimenta, outro pode ser estimulado, estando com fome ou não (Curtis \& Houpt, 1983).

Além dos fatores acima mencionados, fatores influenciados pelas condições climáticas e ambientais podem afetar e alterar os hábitos de pastejo dos bovinos. Os atos espontâneos em ambientes quentes dependem, de certo modo, do estado de equilíbrio térmico do animal em dado momento (Lee, 1954).

Hafez (1973) afirma que os bovinos pastejam de 4 a 5 períodos a cada 24 horas, de acordo com a localidade geográfica. Os maiores períodos ocorrem durante o amanhecer, no meio da manhã, no começo da tarde e próximo do pôr-do-sol, sendo que os períodos onde o pastejo ocorre de maneira mais contínua são no começo da manhã e final da tarde (Hafez, 1973; Fraser \& Broom, 1997). Hafez (1973) acrescenta que, em bovinos de corte a atividade mais intensa de pastejo ocorre das 4 h00 às 8 h00 e das 16 h00 às 20h00, com atividade moderada das 10 h00 às 12 h00. O pastejo no período noturno é mais freqüente no verão, quando os 
bovinos preferem pastejar e beber água nos horários em que as temperaturas são mais amenas (Hafez, 1973; Blackshaw \& Blackshaw, 1994). Durante a parte mais quente do dia os animais preferem ruminar ou permanecer em ócio (descansar). Fraser \& Broom (1997) ressaltam que os bovinos evitam alimentarem-se durante as horas mais quentes do dia, pois procuram sombra neste horário.

Segundo Hafez (1973), períodos de pastejo são alternados com períodos de exploração, ócio e ruminação, e em geral as atividades do rebanho funcionam como uma unidade; ou seja, todos os membros ocupam-se com a mesma atividade ao mesmo tempo, se pastejando, em ócio ou ruminando, sendo que esta última atividade é realizada, na maioria das vezes, enquanto os animais estão deitados ou em decúbito esternal (Hafez, 1973; Fraser \& Broom, 1997), ocorrendo desta maneira de 65 a $80 \%$ do tempo total de ruminação. Tais afirmações estão em consenso com Hodgson (1990), que diz que a maioria dos membros de um grupo de animais normalmente pastejam ao mesmo tempo, e que em muitas circunstâncias o grupo ou rebanho tende a seguir o mesmo padrão de comportamento, existindo uma variação maior entre os indivíduos na atividade de ruminação; complementa que, diariamente, a atividade de pastejo ocupa no total de 6 a 12 horas, dependendo das condições do pasto, e é dividida de 3 a 5 períodos, sendo que as mais longas e intensas ocorrem ao amanhecer e antes do anoitecer, sendo que usualmente um período de ruminação ocorre logo após cada período de pastejo (Hodgson, 1990; Fraser \& Broom, 1997), entretanto, a maior parte da ruminação ocorre à noite, e totaliza de 6 a 8 horas diariamente.

Fraser \& Broom (1997) ressaltam que, a somatória dos períodos de pastejo totalizam de 4 a 14 horas, a de ruminação de 4 a 9 horas sendo dividida entre 15 e 20 períodos (Hafez, 1973; Fraser \& Broom, 1997), e que o período que permanecem deitados totaliza de 9 a 12 horas, durante as 24 horas do dia, podendo variar em regiões tropicais. Durante o dia o gado geralmente descansa em decúbito esternal enquanto rumina, podendo também deitar para descansar sem ruminar, e quando não estão 
pastejando, os animais optam por descansar sem ruminar. Fraser \& Broom (1997) e Silanikove (2000) acrescentam que hábitos diurnos de alimentação são característicos do comportamento de pastejo de bovinos, sendo que sua distribuição está correlacionada com a proporção de horas de luz e escuridão, tendo o pastejo maior prevalência durante as horas de luz; entretanto, a proporção de pastejo diurno e noturno é afetada pelo clima quente, onde a atividade de pastejo ocorre com maior freqüência à noite.

Dentre os comportamentos inerentes ao pastejo, as atividades de deslocamento e/ou locomoção tem grande importância, permitindo ao animal optar por determinada região no interior do piquete e selecionar qual o melhor estágio ou parte da planta forrageira ingerir, dentro de toda a gama de plantas existentes no pasto, pois os bovinos são seletivos no que se refere aos seus hábitos alimentares. Em experimentos de campo, Hafez (1973) e Fraser \& Broom (1997) reportam que, os bovinos pastejam a maior parte do tempo sob a luz do dia e cobrem em média $4 \mathrm{Km}$ por dia, despendendo aproximadamente 2 horas na locomoção, mas esses valores são influenciados pelo tamanho do piquete e pela qualidade da pastagem, além de poderem aumentar consideravelmente em situações de ventos excessivos, clima quente ou úmido e até mesmo se existir abundância de moscas e insetos ao redor. Além da seleção do alimento, os animais podem deslocar-se por grandes distâncias em busca de água, de sal mineral e de proteção (contra o calor ou frio, por exemplo), sendo que tais dispositivos devem estar estrategicamente localizados.

O comportamento de ingestão de água é influenciado por vários fatores, como a temperatura do ambiente (a elevação da temperatura do ar aumenta a necessidade de ingestão de água), a raça em questão (quando em ambientes similares, raças européias e seus cruzamentos consomem mais água que raças zebuínas), a idade e tamanho do animal, ingestão de matéria seca, entre outros (Hafez, 1973; Fraser \& Broom, 1997); acrescentam ainda que, o gado bebe água geralmente de 1 a 4 vezes durante o dia (2 vezes em média), um pouco antes do horário do meio-dia, 
no final da tarde e começo da noite, e raramente ingere-a a noite e no começo da manhã, sendo a ingestão mais freqüente nas estações quentes ou quando estão sobre pastagens de baixa qualidade.

Segundo Paranhos da Costa \& Cromberg (1997), para animais da raça Angus (pelagem vermelha e negra), a distribuição percentual da freqüência de ingestão de água em função do período do dia pode ser assim dividida: $30 \%$ das 6 h00 às $10 \mathrm{~h} 00 ; 40 \%$ das $10 \mathrm{~h} 00$ às $14 \mathrm{~h} 00$ e $30 \%$ das $14 \mathrm{~h} 00$ às 18h00. Para animais da raça Nelore e Brangus os percentuais obtidos foram de $17 \%$, 67\% e 16\% para os mesmo períodos, respectivamente; os autores salientam que a água é um dos mais importantes nutrientes, particularmente para animais mantidos em climas quentes, pois exerce efeito no bem-estar térmico, ocasionado pelo resfriamento direto - desde de que a água esteja em temperatura inferior à do corpo do animal - e serve como veículo primário de transferência de calor através da evaporação cutânea e respiratória.

As reações de várias raças de gado em diferentes condições climáticas vem sendo descobertas em estudos a campo (Findlay, 1950), no entanto, têm se observado que um fator atua sobremaneira no comportamento de bovinos a pasto: a alta temperatura do ar.

A radiação solar é o fator preponderante na termorregulação de ruminantes a pasto (Gebremedhin, 1985). Blackshaw \& Blackshaw (1994) acrescentam que a radiação solar é componente significante na carga de calor em bovinos e sua redução, através do uso da sombra, é importante para manter o consumo de alimento, e por conseqüência, o crescimento, e até mesmo a sobrevivência dos animais. Findlay (1950), Hafez (1973), Fraser \& Broom (1997) e Silanikove (2000) atentam para o fato de que a redução na ingestão de alimento, a diminuição da atividade de pastejo e a procura pela sombra são respostas imediatas ao estresse térmico pelo calor, pois pastejando menos há diminuição tanto na ingestão de alimento (o que reduz o ganho de calor pela atividade de digestão), quanto na atividade muscular que envolve o pastejo, que também produz calor. 
Além disso, a sombra proporciona bem-estar ao animal, devido à diminuição da temperatura do ambiente e conseqüentemente do animal, o que ocasiona um aumento na ingestão de alimentos e água, principalmente se estes estiverem sob a sombra (Head, 1995). Paranhos da Costa \& Cromberg (1997) e Paranhos da Costa (2000) destacam que, em ambientes quentes com alta incidência de radiação solar, deve-se proporcionar sombra aos animais, reduzindo assim o aquecimento corporal e facilitando a termorregulação, pois o aperfeiçoamento do ambiente térmico traz benefícios à produção animal, aumentando a produtividade e a eficiência na utilização de alimentos.

Blackshaw \& Blackshaw (1994) acrescentam que existe uma preocupação com o bem-estar, relativa ao estresse térmico pelo calor e a provisão de sombra para o gado bovino, pois em climas quentes, o gado procura sombra com freqüência, e esta pode reduzir a carga de radiação em $30 \%$ ou mais (Blackshaw \& Blackshaw, 1994; Paranhos da Costa \& Cromberg, 1997). De maneira geral, pode-se afirmar que os animais buscam o conforto e evitam o desconforto, assim, em situações e regiões onde a radiação solar direta é intensa e a temperatura do ar é alta (maior que $2^{\circ} \mathrm{C}$ ), a sombra é procurada pela maioria das raças européias de gado (Fraser \& Broom, 1997).

Quando o sombreamento natural não está satisfatoriamente disponível, o sombreamento artificial proporciona uma melhora considerável nas condições térmicas ambientais (Bucklin \& Bray, 1998). Blackshaw \& Blackshaw (1994) citam valores entre $1,8 \mathrm{~m}^{2}$ e 4,2 $\mathrm{m}^{2}$ de sombra por animal (bovinos de leite), sugerindo 5,6 $\mathrm{m}^{2}$ como desejável. De acordo com Silanikove (2000) estruturas de sombreamento bem projetadas reduzem a carga de calor total em $30 \%$ a $50 \%$, sendo que as perdas de calor através da respiração totalizam somente 15\%.

Blackshaw \& Blackshaw (1994), Fraser \& Broom (1997), Paranhos da Costa \& Cromberg (1997), Paranhos da Costa (2000) e Silanikove (2000) atentam para o fato de que os animais buscam áreas sombreadas nas horas mais quentes do dia, evitando a radiação solar direta. Paranhos 
da Costa \& Cromberg (1997) ressaltam para o fato de que os animais procuram a sombra praticamente o dia todo, inclusive em horários com baixa incidência de radiação solar.

Durante o clima quente o gado pode usar a sombra, e seu comportamento de pastejo pode ser influenciado pela disponibilidade desta, deixando-a somente para procurar água no final da tarde ou à noite, sendo que em dias quentes o gado gasta mais tempo deitado, especialmente quando há pouco vento (Blackshaw \& Blackshaw, 1994); os autores acrescentam que a alta temperatura e umidade influenciam a procura por sombra em animais da raça Shorthorn, que permaneceram de 9 a 11 horas sob a sombra durante o verão em condições tropicais, mas em condições excepcionais de altas temperaturas do ar, da carga de radiação direta e umidade todas as raças de gado tornam-se vulneráveis ao estresse por calor, podendo em certos casos ocasionar a morte.

Estudos realizados com a raça Angus (pelagem negra) citados por Findlay (1950), com a temperatura do ar entre $24,4^{\circ} \mathrm{C}$ e $39,4^{\circ} \mathrm{C}$, mostram que os hábitos dos animais variam conforme a condição climática. Em situações de céu nublado e sem vento, os animais permaneceram em atividades de pastejo, descansando ao sol e descansando sob a sombra por, respectivamente, $79 \%$, $0 \%$ e $21 \%$ do tempo do dia para animais com pêlo longo, e 69\%, 0\% e 31\% para animais com pêlo tosquiado. Animais cruzados $1 / 2$ Angus e $1 / 2$ Brahman permaneceram por $73 \%$, 0\% e 27\% para as mesmas atividades, respectivamente. Em condições de sol sem vento, os animais puros de pêlo longo, de pêlo tosquiado e meio-sangue permaneceram, respectivamente, 54\%, 0\%, 46\%; 44\%, 2\%, 54\%, e $62 \%$, $28 \%, 10 \%$ para as atividades de pastejo, descanso ao sol e descanso sob a sombra. Para condições de sol, com vento, os resultados obtidos foram $75 \%, 0 \%, 25 \%$; 64\%, 3\%, 33\% e $83 \%, 17 \%$, 0\%, respectivamente para as mesmas atividades. Mesmo tosquiando os animais Angus não houve aumento no tempo de pastejo.

Paranhos da Costa \& Cromberg (1997) citam que, os bovinos da raça Angus (pelagem negra e vermelha) permanecem aproximadamente 
$20 \%$ do tempo total no qual ficam sob a sombra no período das 6 h00 às $10 \mathrm{~h} 00,60 \%$ das $10 \mathrm{~h} 00$ às $14 \mathrm{~h} 00$ e $20 \%$ das $14 \mathrm{~h} 00$ às $18 \mathrm{~h} 00$. Salientam ainda que, os animais de pelagem vermelha permaneceram sob a sombra $14 \%$ do dia (6h00 às $18 \mathrm{~h} 00$ ) enquanto os animais de pelagem negra $22 \%$ para o mesmo período. Para o horário mais quente (das $10 \mathrm{~h} 00$ às 14h00) os resultados obtidos foram de $10 \%$ para os animais vermelhos e $14 \%$ para os pretos.

Fraser \& Broom (1997) reportam que são comportamentos comuns em animais a procura por sombra, a defecação e urinação disciplinada em locais pré-selecionados, o abrigo do vento e também molhar o corpo no calor (denominados cuidados com o corpo - do inglês body care).

Segundo reporta Hafez (1973) em algumas áreas, o uso de sprinklers (banhos por aspersão) pode ocasionar um aumento no tempo de pastejo. Ford (1992) afirma que a sombra e a água para banho oferecem condições similares de termorregulação, pois as temperaturas retais de animais submetidos apenas à sombra foram estatisticamente iguais às de animais com acesso à água. Blackshaw \& Blackshaw (1994) acrescentam que, o balanço entre a carga de calor e a dissipação deste pode ser alcançada pela redução da radiação solar e também molhando os animais suficientemente para reduzir a temperatura da pele.

Os bovinos podem permanecer em pé na água quando a temperatura é alta (Fraser \& Broom, 1997). Acrescentam que o gado tem predileção por permanecer em pé, com os pés e a parte inferior dos membros na água por longos períodos, em dias ensolarados e quentes; e que todo o grupo de animais (ou rebanho) freqüentemente adota a mesma estratégia de termorregulação.

Para um melhor entendimento da dinâmica das respostas dos animais às mudanças de ambiente, são necessários estudos que quantifiquem o impacto do uso de recursos provedores de bem-estar térmico aos animais, bem-estar este relacionado diretamente a produção e a reprodução. 
Pelo exposto, se evidenciou a importância de que o presente trabalho tivesse como objetivo geral o avanço no entendimento da utilização de recursos provedores de bem-estar térmico que podem ser incorporados aos sistemas de produção de bovinos a pasto, visando melhorar os resultados de produtividade, especialmente quando da utilização de bovinos de origem européia em regiões de clima tropical.

Como objetivos específicos pretendeu-se quantificar a freqüência de utilização dos recursos sombra e água para imersão, disponibilizados a pasto para touros da raça Angus - variedade vermelha - de pelagem curta e longa, e avaliar também as causas e funções dos diferentes comportamentos, detectando as possíveis preferências por água para imersão ou sombra ou interações entre esses recursos, sobre seus aspectos comportamentais. 


\section{MATERIAL E MÉTODOS}

A fase experimental foi realizada nas dependências da Universidade de São Paulo, no Campus Administrativo de Pirassununga, que se encontra a 2180'00" de latitude sul e 4725'42" de longitude oeste, a uma altitude de $634 \mathrm{~m}$ e apresenta clima do tipo Cwa, segundo classificação de Köeppen (Oliveira \& Prado, 1984). A temperatura média anual é de $22,0^{\circ} \mathrm{C}$ e a pluviosidade média anual é próxima a 1363 mm (Martello, 2002).

\subsection{Tratamentos, animais e condições de manejo}

O experimento realizou-se em três piquetes experimentais do Laboratório de Biometeorologia da Faculdade de Zootecnia e Engenharia de Alimentos (FZEA), da USP. Os piquetes contíguos utilizados possuíam área de aproximadamente 0,3 hectare cada e eram dotados de bebedouros artificiais. Um cocho móvel coberto foi utilizado para suplementação alimentar e mineral. A pastagem existente, em ambos os tratamentos foi a gramínea Brachiaria decumbens cultivada, e os piquetes foram divididos por cerca de arame farpado (paraguaia). Para cada piquete foi destinado um tratamento diferente (Figura 1 - a ilustração não obedece nenhum tipo de escala):

TS $^{2}$ : disponibilidade de sombra natural e artificial (esquerda);

TSA $^{2}$ : disponibilidade de sombra artificial e de água para imersão (centro);

TA $^{2}$ : disponibilidade de água para imersão (direita).

\footnotetext{
${ }^{2}$ As siglas $T S, T S A$ e $T A$ serão utilizadas como referência para cada um dos três tratamentos
} 


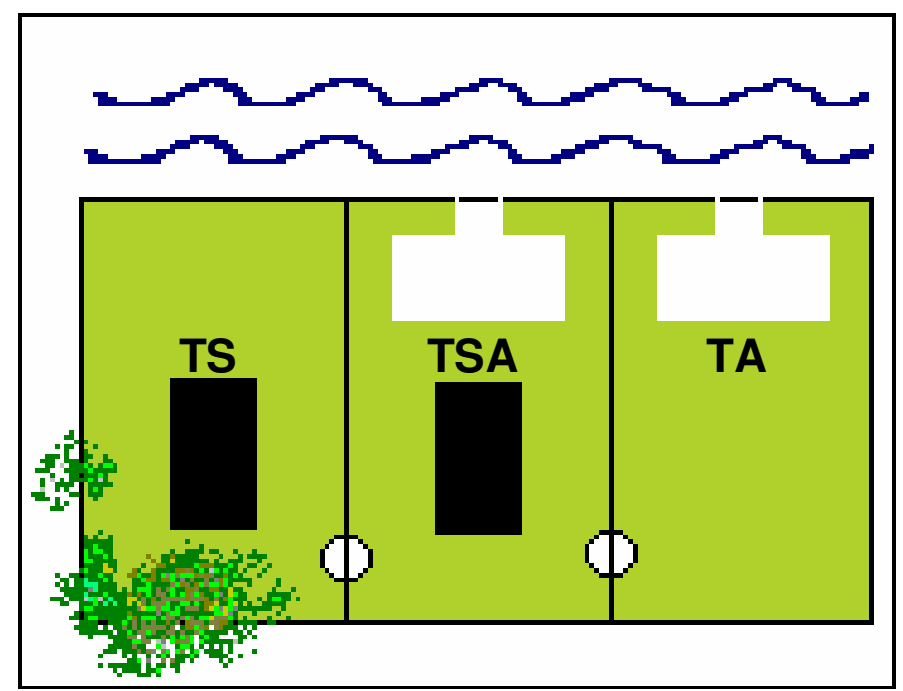

Figura 1 - Visão esquemática dos três piquetes experimentais

As sombras artificiais nos tratamentos TS e TSA são de malha de polietileno, com $80 \%$ de filtração (retenção solar), cobrindo uma área de $6 \mathrm{x}$ $10 \mathrm{~m}$, totalizando $60 \mathrm{~m}^{2}$ cada, oferecendo sombras com áreas suficientemente grandes para abrigar todos os animais ao mesmo tempo (aproximadamente $7,5 \mathrm{~m}^{2}$ por animal). A água para imersão dos tratamentos TSA e TA foi uma piscina cavada no chão, com $5 \mathrm{~m}$ de largura por $10 \mathrm{~m}$ de comprimento e $1 \mathrm{~m}$ de profundidade, o que também atende às necessidades de todos os animais, mesmo no caso de todos decidirem utilizá-la ao mesmo tempo, permitindo ainda que os animais mantivessem distância suficiente entre si.

Foram utilizados 8 bovinos machos inteiros da raça Angus (Bos taurus taurus), 7 com pelagem vermelha e 1 com pelagem negra, com idade entre 14 e 15 meses e média de peso de $400 \mathrm{Kg}$, sendo que 4 possuíam pelagem de comprimento médio/longo e 4 de comprimento curto (confira Tabela 1, item 4.1). Os animais foram marcados individualmente com tinta branca atóxica, com números de 1 a 8 . 0 grupo de 8 animais foi mantido, evitando o efeito de interação entre animais de tratamentos adjacentes, e os piquetes experimentais foram utilizados um de cada vez. Esta metodologia foi utilizada por Ablas (2002). 
Os animais foram suplementados a pasto com $80 \mathrm{Kg}$ de silagem de milho e $40 \mathrm{Kg}$ de concentrado, quantidades estas divididas igualmente em 2 horários: às $6 \mathrm{~h} 45$ e às 18h05, diariamente, de forma que todos permaneceram nas instalações dos piquetes experimentais, mesmo nos dias em que não foram observados.

As pesagens dos animais foram realizadas no primeiro e no último dia do experimento. O desempenho ponderal dos animais foi calculado levando em consideração o período experimental total. A mensuração do comprimento do pêlo dos animais (medida no dorso) foi efetuada no primeiro dia do experimento.

\subsection{Variáveis climáticas}

As variáveis climáticas (temperatura do ar, umidade relativa, radiação solar, pluviosidade, e velocidade do ar) foram registradas automaticamente a cada 15 minutos por uma estação meteorológica eletrônica $\left(\right.$ Campbell $\left.^{\circledR}\right)$, durante todo o período de adaptação e experimental. Adicionalmente, foram coletadas, também a cada 15 minutos, as temperaturas de globo negro $(\mathrm{TGN})^{3}$ ao sol e à sombra, e calculado o ITGU.

Para as análises estatísticas foram utilizados todos os dados coletados durante o período de observação experimental efetivo (das 8h00 às 18h00), e foram realizadas correlações de Pearson para todas as variáveis climáticas. O software utilizado para as análises estatísticas desses dados foi o Statistica ${ }^{\circledR}$ (version 5$)$.

\subsection{Comportamento}

O registro de comportamento foi feito através de coleta instantânea e contínua, com amostragem pelo método focal, preconizado por Martin \& Bateson (1986), a cada 15 minutos, de forma direta por períodos contínuos

\footnotetext{
${ }^{3}$ A sigla TGN será utilizada como referência à temperatura do globo negro
} 
de 10 horas (das $8 \mathrm{~h} 00$ às 18h00). As variáveis comportamentais observadas foram: Posição (ao sol, à sombra e na água), Postura (em pé ou deitado) e Atividade (em pastejo, em ruminação, em deslocamento, em ócio ou outras atividades), conforme as planilhas elaboradas nos Anexos $A$ e B. O consumo de água e de sal mineral foi incorporado em outras atividades. E a utilização da sombra, ainda que fosse sempre sob o sol (já que não havia sombra em nenhum ponto da piscina para imersão), foi considerada independente da posição do animal ao sol, para efeito de registro. Os valores absolutos (tempo em minutos) obtidos nas observações comportamentais foram transformados em freqüências (porcentagens) para facilitar possíveis comparações com outros trabalhos.

O período de adaptação mínimo foi de 48 horas entre cada tratamento. O período de observação efetivo foi de 3 dias para cada tratamento, ou seja, 3 períodos de 10 horas. O período experimental teve início no dia 08 de novembro de 2002 e duração de vinte dias.

A ordem dos tratamentos foi estabelecida com o intuito de manter as condições semelhantes às encontradas na fazenda de origem dos animais. As observações tiveram início no tratamento TS, que dispunha de sombra natural e artificial passando para os tratamentos TSA e TA, respectivamente.

Foram realizadas correlações de Spearman e Kendall tau (nãoparamétricas) e de Pearson para as análises estatísticas das variáveis comportamentais de posição (ao sol, à sombra e na água) encontradas no etograma de trabalho (Anexo $A$ ), sempre levando em consideração todas as observações realizadas durante o período experimental efetivo, das 8 h00 às 18 h00.

O trabalho envolveu múltiplas variáveis intervenientes e uma análise multivariada é indicada. Por constituir uma análise indicativa, simples e eficiente, a análise de conglomerados - ou cluster - foi adotada para avaliação do comportamento, levando em consideração as diferentes variáveis simultaneamente. Foram realizadas análises com ligação completa (agrupamento por dissimilaridade) e simples (agrupamento por 
similaridade), ambas levando em consideração as características individuais de cada animal: comprimento de pêlo, peso ao nascer, peso na desmama e peso na entrada e na saída do experimento (cf. Tabelas 1 e 2); e também o resultado comportamental individual: freqüências de permanência ao sol, uso dos recursos de sombra e água, freqüência de permanência em pé ou deitado e freqüência das atividades de pastejo, ruminação, deslocamento, ócio ou outras (cf. Tabela 15 do Anexo C). A utilização do agrupamento por dissimilaridade e similaridade foi escolhida em função da facilidade de interpretação das características dos grupos formados. Foram realizadas quatro análises multivariadas por conglomerados, sendo uma para cada uns dos tratamentos (TS, TSA e TA) e uma levando em consideração todos os tratamentos simultaneamente. A Tabela 15 do Anexo C apresenta a média de surtos (posições, posturas e atividades) dos animais nos diferentes tratamentos. Estes dados foram utilizados para a realização das quatro análises de conglomerados, juntamente com os dados da Tabela 1 (características individuais de pelagem e peso dos animais do experimento). O software utilizado para as análises estatísticas desses dados foi o Statistica ${ }^{\circledR}$ (version 5).

Adicionalmente, foram realizados testes para determinar quando as séries temporais diferem significativamente do acaso (teste de Rayleigh) e para testar se duas séries temporais são significativamente diferentes (teste de Watson-Willians), conforme preconizado por Lehner (1996). Estes testes foram realizados utilizando-se do software Microsoft Excel ${ }^{\circledR}$. 


\section{RESULTADOS}

\subsection{Desempenho dos animais}

Os valores para o peso ao nascer (PN), peso na desmama (PD), peso na entrada do experimento (Peso 1$)^{4}$ e na saída (Peso 2$)^{4}$, e o comprimento da pelagem (Pêlo) dos diferentes animais ${ }^{5}$ encontram-se na Tabela 1:

Tabela 1. - Características individuais de pelagem e peso dos animais do experimento (Pirassununga - SP, 2002)

\begin{tabular}{|c|c|c|c|c|c|}
\hline Animal $^{5}$ & PN & PD & Peso 1 $^{4}$ & ${\text { Peso } 2^{4}}$ & Pêlo \\
\hline A1 & $31 \mathrm{Kg}$ & $207 \mathrm{Kg}$ & $395 \mathrm{Kg}$ & $415 \mathrm{Kg}$ & $3,00 \mathrm{~cm}$ \\
\hline A2 & $30 \mathrm{Kg}$ & $221 \mathrm{Kg}$ & $412 \mathrm{Kg}$ & $433 \mathrm{Kg}$ & $1,30 \mathrm{~cm}$ \\
\hline A3 & $38 \mathrm{Kg}$ & $238 \mathrm{Kg}$ & $414 \mathrm{Kg}$ & $427 \mathrm{Kg}$ & $2,00 \mathrm{~cm}$ \\
\hline A4 & $35 \mathrm{Kg}$ & $240 \mathrm{Kg}$ & $403 \mathrm{Kg}$ & $416 \mathrm{Kg}$ & $2,50 \mathrm{~cm}$ \\
\hline A5 & $32 \mathrm{Kg}$ & $218 \mathrm{Kg}$ & $383 \mathrm{Kg}$ & $390 \mathrm{Kg}$ & $1,80 \mathrm{~cm}$ \\
\hline A6 & $43 \mathrm{Kg}$ & $245 \mathrm{Kg}$ & $423 \mathrm{Kg}$ & $433 \mathrm{Kg}$ & $1,00 \mathrm{~cm}$ \\
\hline A7 & $30 \mathrm{Kg}$ & $240 \mathrm{Kg}$ & $382 \mathrm{Kg}$ & $411 \mathrm{Kg}$ & $1,00 \mathrm{~cm}$ \\
\hline A8 & $37 \mathrm{Kg}$ & $225 \mathrm{Kg}$ & $393 \mathrm{Kg}$ & $416 \mathrm{Kg}$ & $0,50 \mathrm{~cm}$ \\
\hline
\end{tabular}

Os resultados das pesagens dos animais e das mensurações de comprimento da pelagem foram subdivididos em três categorias que são apresentadas na Tabela 2. A Categoria 1 distingue os animais com pesos mais leves e/ou pêlos curtos, a Categoria 2, representa animais com pesos

\footnotetext{
${ }_{5}^{4}$ As siglas Peso 1 e Peso 2 serão utilizadas como referência para cada uma das pesagens

${ }^{5}$ A sigla $A 1$ refere-se ao animal número 1, e assim sucessivamente, até o animal número 8
} 
intermediários, e a Categoria 3, os animais com pesos mais elevados e/ou pêlos longos ${ }^{6}$, para as respectivas características:

Tabela 2. - Categorias de peso e pelagem (Pirassununga - SP, 2002)

\begin{tabular}{|c|c|c|c|}
\cline { 2 - 4 } \multicolumn{1}{c|}{} & Categoria 1 & Categoria 2 & Categoria 3 \\
\hline PN & $\leq 32 \mathrm{Kg}$ & $>32 \mathrm{Kg} \mathrm{e} \leq 38 \mathrm{Kg}$ & $>38 \mathrm{Kg}$ \\
\hline PD & $\leq 218 \mathrm{Kg}$ & $>218 \mathrm{Kg} \mathrm{e} \leq 225 \mathrm{Kg}$ & $>225 \mathrm{Kg}$ \\
\hline Peso 1 & $\leq 395 \mathrm{Kg}$ & $>395 \mathrm{Kg} \mathrm{e} \leq 403 \mathrm{Kg}$ & $>403 \mathrm{Kg}$ \\
\hline Peso 2 & $<410 \mathrm{Kg}$ & $\geq 410 \mathrm{Kg} \mathrm{e} \leq 416 \mathrm{Kg}$ & $>416 \mathrm{Kg}$ \\
\hline Pêlo & $\leq 1,30 \mathrm{~cm}$ & -- & $>1,30 \mathrm{~cm}$ \\
\hline
\end{tabular}

\subsection{Variáveis climáticas}

Os resultados obtidos para temperatura do ar nos diferentes horários do dia e seus valores são apresentados na Figura 2. A evolução das temperaturas do ar durante o experimento deu-se de maneira semelhante para os diferentes dias de coleta e, dentro de cada tratamento, o comportamento da variável sempre foi semelhante. As correlações dentro dos tratamentos e entre tratamentos apresentam-se na Tabela 3 do Anexo C.

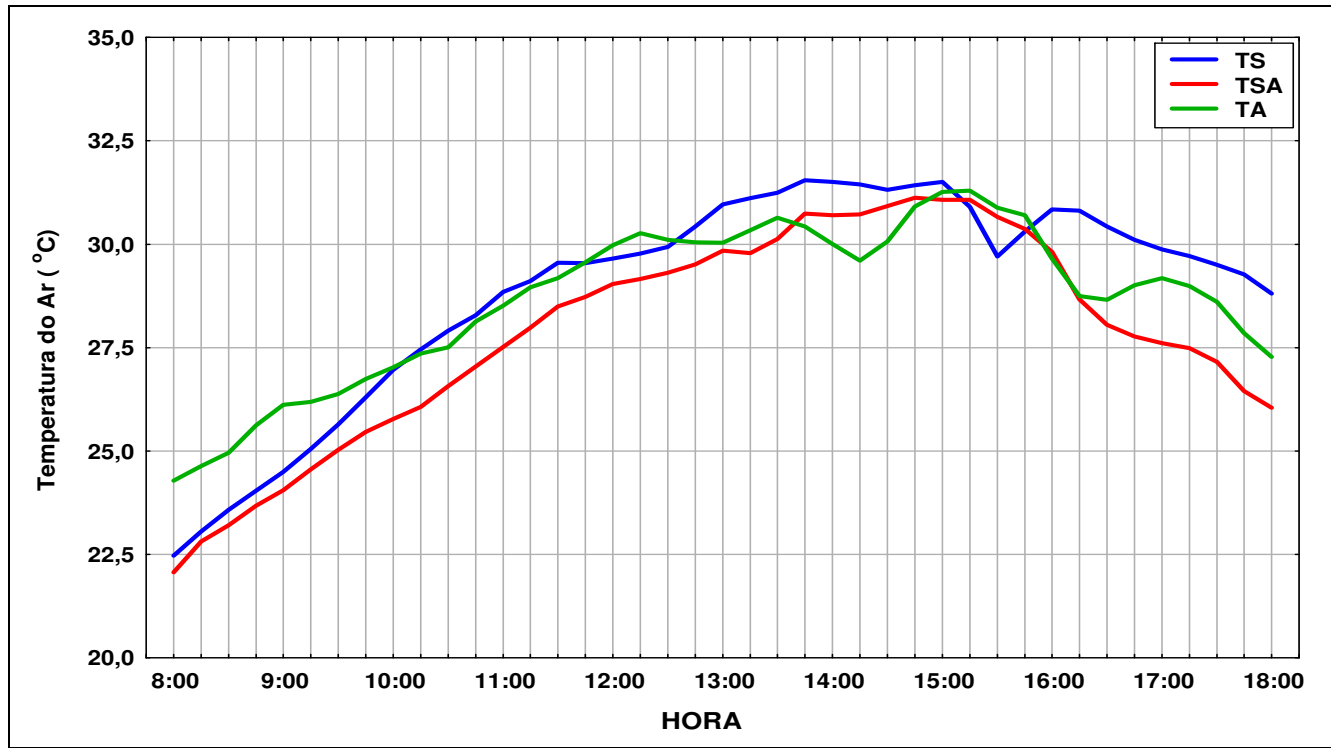

Figura 2 - Evolução horária da temperatura do ar (média de cada tratamento)

\footnotetext{
${ }^{6}$ Animais com comprimento de pêlo superior a $1,30 \mathrm{~cm}$ foram considerados de pelagem longa
} 
Para a umidade relativa do ar, os resultados obtidos nos diferentes horários do dia e seus valores são apresentados na Figura 3. Observou-se que as evoluções das umidades relativas deram-se de maneira semelhante para os diferentes dias de observação e que dentro de cada tratamento a evolução sempre foi semelhante. As correlações das umidades relativas são apresentadas na Tabela 4 do Anexo C.

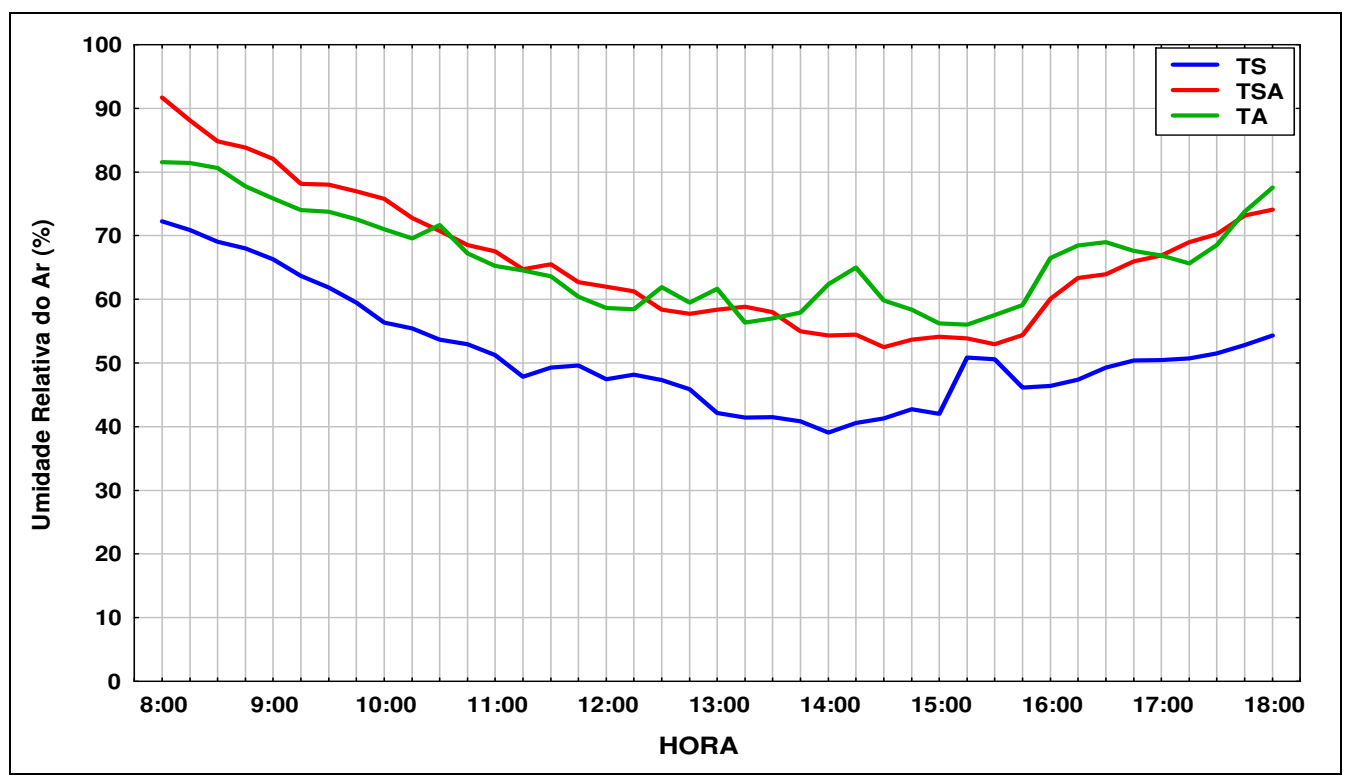

Figura 3 - Evolução horária da umidade relativa do ar (média de cada tratamento)

Com relação aos resultados obtidos para radiação global nos diferentes horários do dia, seus valores apresentam-se na Figura 4. As radiações globais durante o experimento evoluíram de maneira similar para os diferentes dias de observação do experimento, e dentro de cada tratamento a evolução da variável sempre foi semelhante (as correlações apresentam-se na Tabela 5 do Anexo C). 


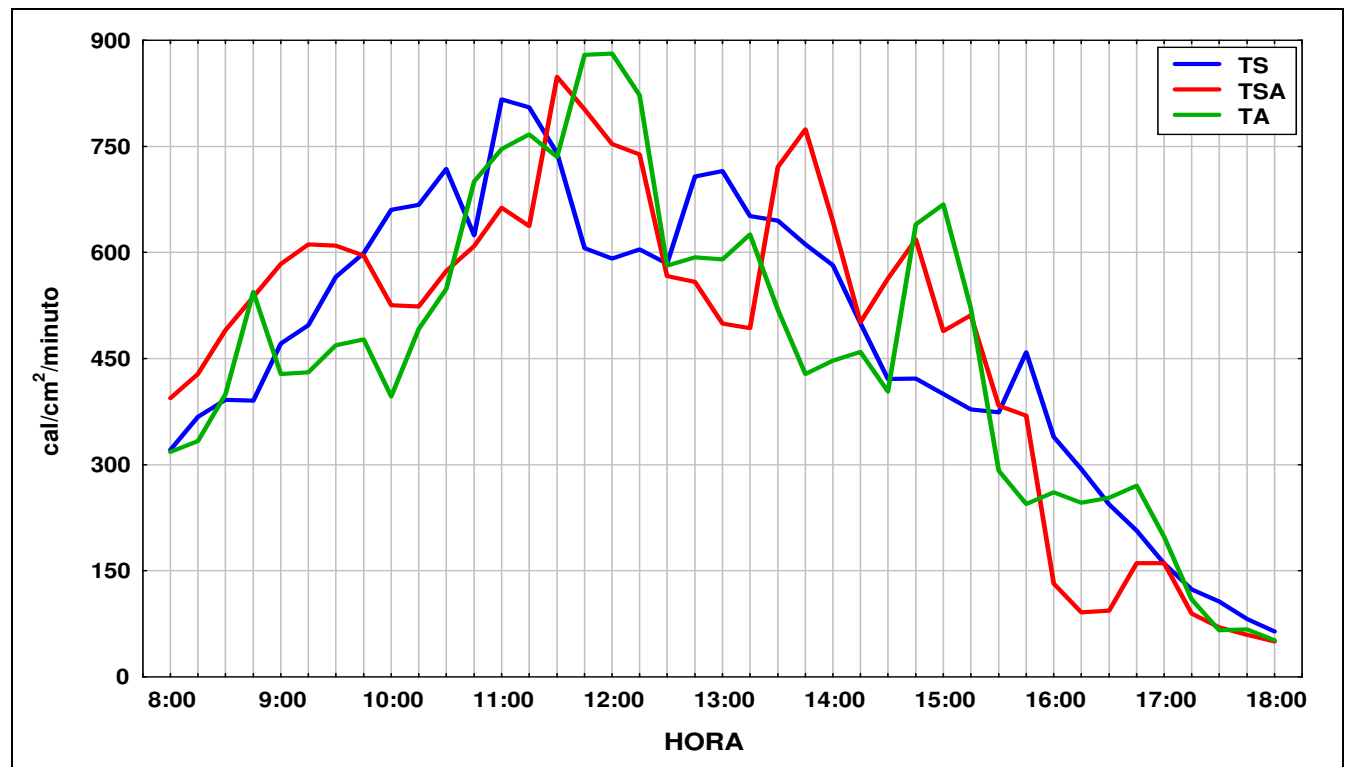

Figura 4 - Evolução horária da radiação global (média de cada tratamento)

Para a velocidade do ar, os resultados obtidos nos diferentes horários do dia e seus valores encontram-se na Figura 5. A evolução das velocidades do ar durante o experimento apresentou grande variação entre os diferentes dias de um mesmo tratamento e entre tratamentos (as correlações podem ser observadas na Tabela 6 do Anexo C).

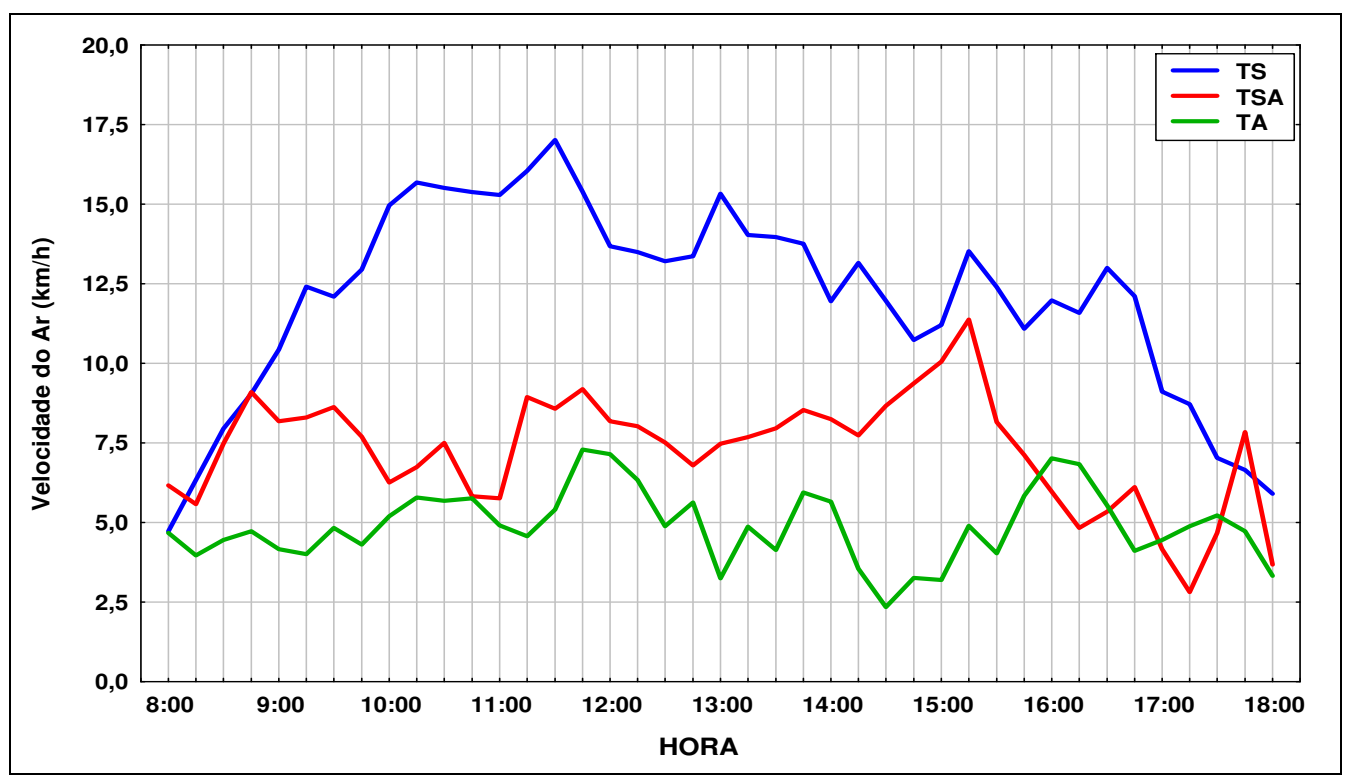

Figura 5 - Evolução horária da velocidade do ar (média de cada tratamento) 
Os resultados obtidos para temperatura do globo negro (TGN) ao sol e à sombra nos diferentes horários do dia e seus valores são apresentados na Figura 6 e na Figura 7, respectivamente. As evoluções das TGNs ao sol e à sombra durante o experimento foram semelhantes para os diferentes dias de coleta, assemelhando-se sempre entre e dentro de tratamentos, conforme apresentado nas Tabelas 7 e 8 do Anexo C. As TGNs ao sol e à sombra apresentaram alta correlação $(0,89)$ entre si.

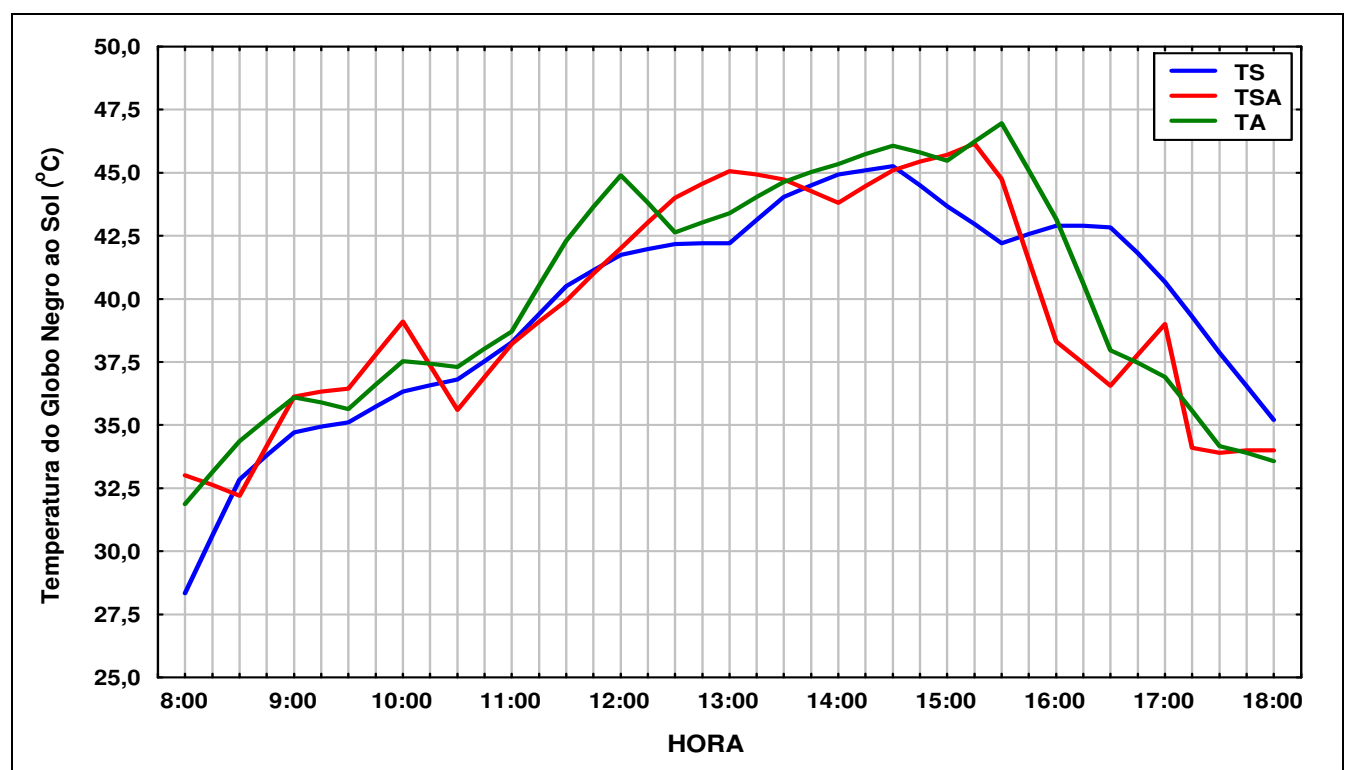

Figura 6 - Evolução horária da TGN ao sol (média de cada tratamento)

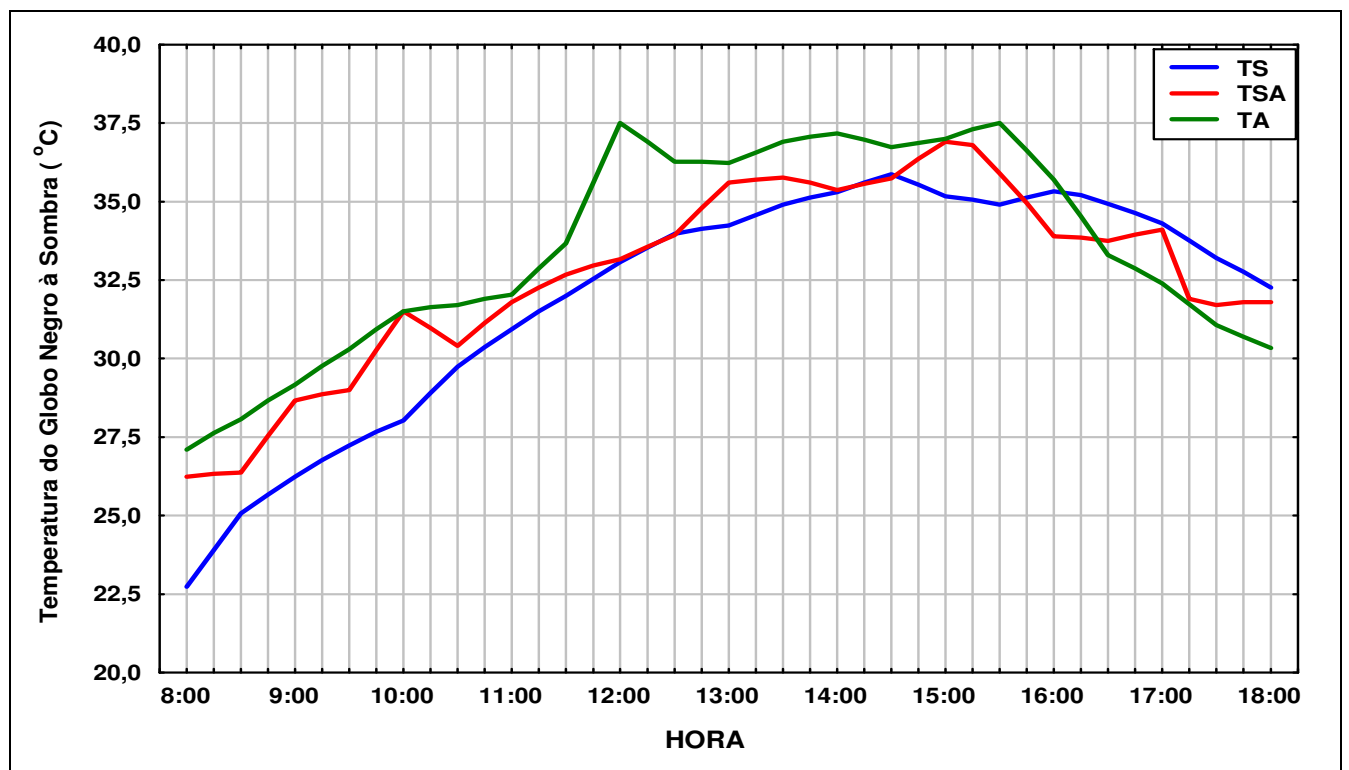

Figura 7 - Evolução horária da TGN à sombra (média de cada tratamento) 
Os resultados obtidos para o ITGU nos diferentes horários do dia e seus valores são apresentados na Figura 8. O ITGU evoluiu analogamente para os diferentes dias do experimento, sendo sempre semelhante dentro de cada tratamento, como pode ser observado pelas correlações apresentadas na Tabela 9 do Anexo C.

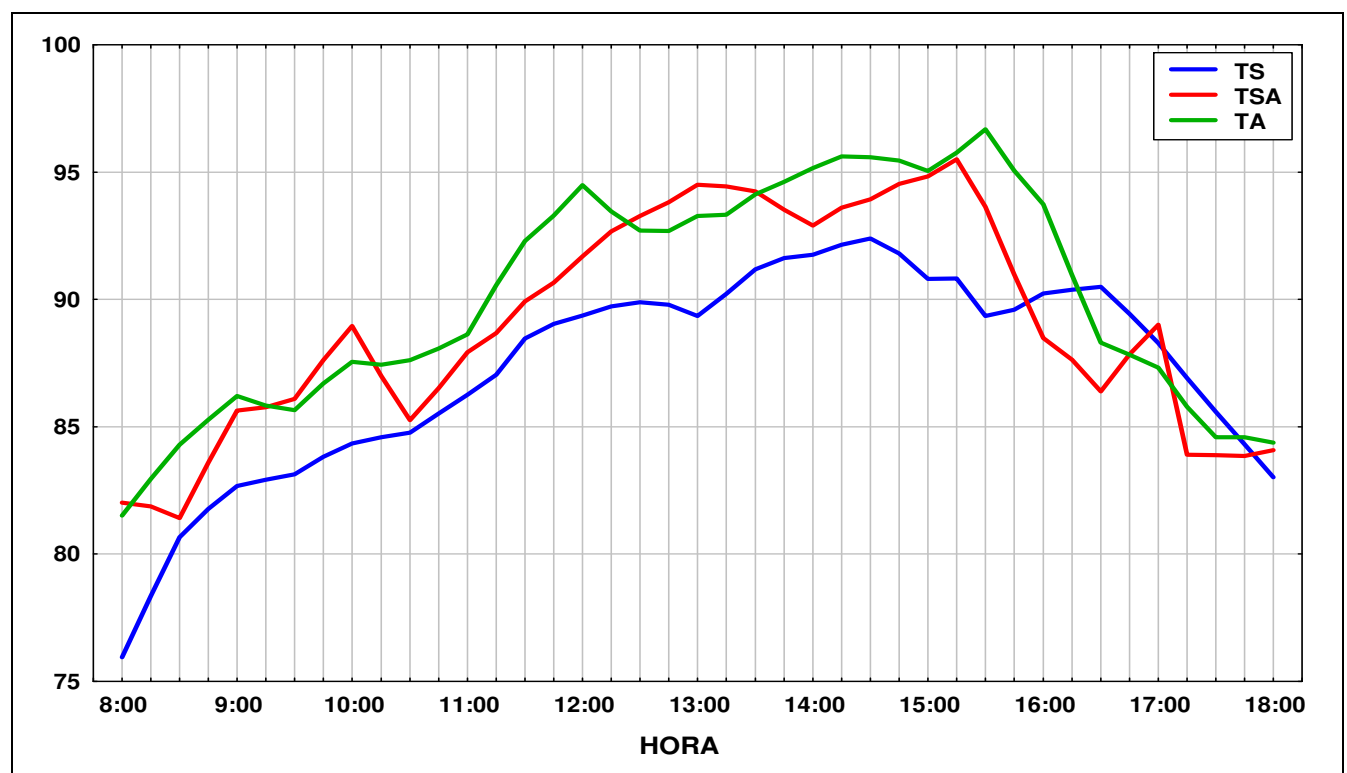

Figura 8 - Evolução horária do ITGU (média de cada tratamento)

Em alguns dias, algumas das medidas das variáveis climáticas mostraram-se diferentes significativamente; entretanto estas diferenças não foram correlacionadas aos diferentes comportamentos dos animais e não serão discutidas no presente trabalho.

\subsection{Comportamento}

A distribuição horária das freqüências médias de permanência ao sol para cada tratamento pode ser observada na Figura 9. Nenhum animal apresentou freqüência temporal ao acaso para a posição "Ao Sol" (Tabela 10 do Anexo C). A freqüência de permanência dos animais ao sol mostrou alta correlação (correlação de Pearson) entre os tratamentos TS e TSA, o que não ocorreu com o tratamento TA, que não se correlacionou significativamente com os tratamentos TS e TSA. No entanto, os animais 
foram altamente correlacionados dentro de um mesmo tratamento, como pode ser observado na Tabela 11 do Anexo C.

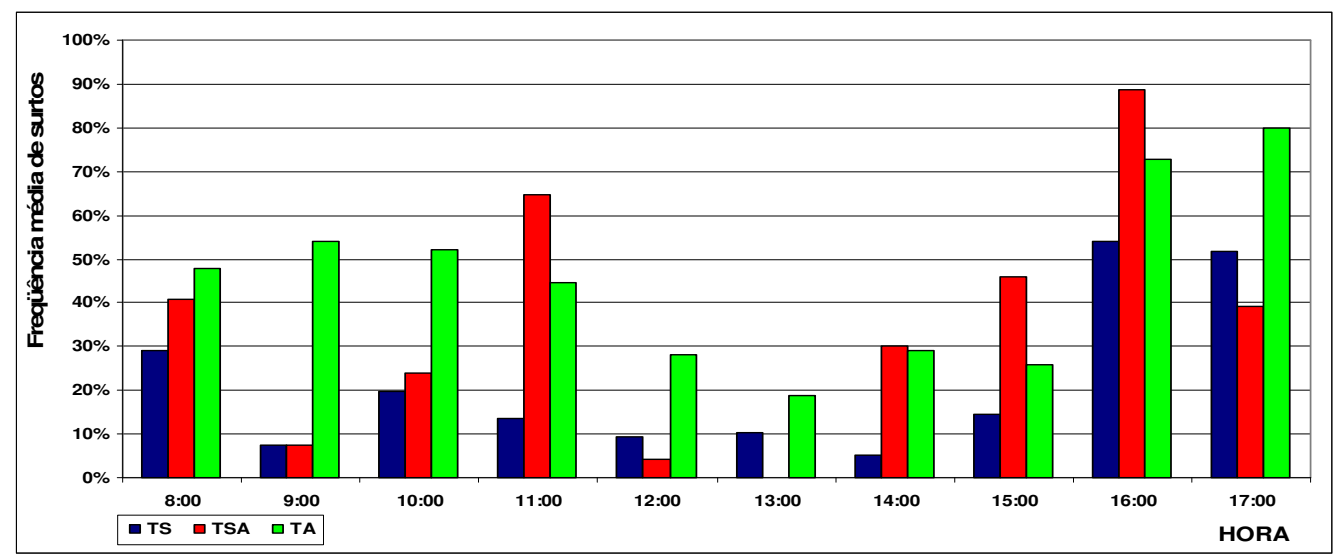

Figura 9 - Distribuição horária da freqüência de surtos da posição "Ao Sol" (média de cada tratamento)

A Tabela 12 apresenta as séries temporais significativamente diferentes para o comportamento de permanência "Ao Sol" e "À Sombra" dos 8 animais para os três tratamentos (TS, TSA e TA).

Tabela 12. - Amostras temporais significativamente diferentes $(\alpha=0,05)$ para um mesmo animal em diferentes tratamentos (Pirassununga - SP, 2003)

\begin{tabular}{|c|c|c|c|c|c|c|}
\cline { 2 - 8 } \multicolumn{1}{c|}{} & \multicolumn{3}{c|}{ PERMANÊNCIA AO SOL } & \multicolumn{2}{c|}{ PERMANÊNCIA A SOMBRA } \\
\hline A1 & TS $\neq$ TA & - & - & - & TSA $\neq$ TS & - \\
\hline A2 & TS $\neq$ TA & - & TA $\neq$ TSA & - & TSA $\neq$ TS & TA $\neq$ TSA \\
\hline A3 & - & - & - & TS $\neq$ TA & TSA $\neq$ TS & - \\
\hline A4 & TS $\neq$ TA & - & TA $\neq$ TSA & - & TSA $\neq$ TS & - \\
\hline A5 & TS $\neq$ TA & TSA $\neq$ TS & - & - & TSA $\neq$ TS & TA $\neq$ TSA \\
\hline A6 & TS $\neq$ TA & TSA $\neq$ TS & - & - & TSA $\neq$ TS & - \\
\hline A7 & - & - & - & - & TSA $\neq$ TS & - \\
\hline A8 & - & - & - & TS $\neq$ TA & - & - \\
\hline
\end{tabular}

A distribuição horária das freqüências médias de permanência sob a sombra para cada tratamento apresenta-se na Figura 10. No caso do sombreamento ocorreu um fato sui generis no tratamento com disponibilidade de água para imersão (TA): a princípio, este tratamento não disponibilizaria sombra alguma aos animais, mas o cocho móvel utilizado para a suplementação alimentar e mineral produzia uma sombra projetada 
de aproximadamente $6 \mathrm{~m}^{2}$, sombra esta que mesmo não sendo suficientemente grande para acomodar todos os animais ao mesmo tempo, foi utilizada como recurso de proteção contra o sol em alguns horários do dia. Este comportamento foi registrado e levado em consideração. A freqüência de utilização do recurso de sombreamento pelos animais mostrou-se altamente correlacionada entre os tratamentos TS e TSA. Não houve correlação significativa do uso da sombra entre o tratamento TA e os demais tratamentos. No entanto, os animais apresentaram correlações significativas dentro de um mesmo tratamento, como pode ser observado na Tabela 13 do Anexo C. A freqüência temporal de permanência do animal 4 (A4) sob a sombra no tratamento TA, mostrou ser devida ao acaso (Tabela 10 do Anexo C).

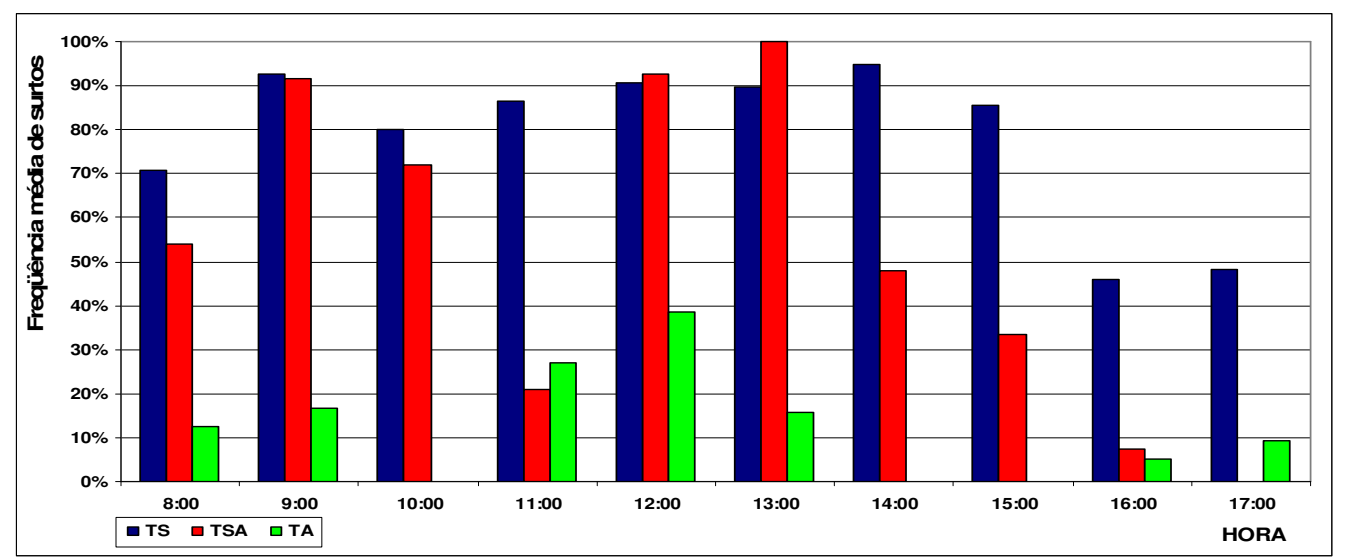

Figura 10 - Distribuição horária da freqüência de surtos da posição "À Sombra" (média de cada tratamento)

A freqüência de uso do recurso de água para imersão deu-se de maneira diferente para os tratamentos TSA e TA. Sua distribuição horária pode ser observada na Figura 11. No tratamento com disponibilidade de sombra artificial e água para imersão (TSA) a freqüência temporal apresentada pelos animais $A 1, A 2, A 3, A 5, A 6$ e A7 mostrou ser devida ao acaso (Tabela 10 do Anexo $\mathrm{C}$ ). Houve correlação significativa entre os animais dentro de um mesmo tratamento, o que pode ser observado nos dados apresentados na Tabela 14 do Anexo C. 


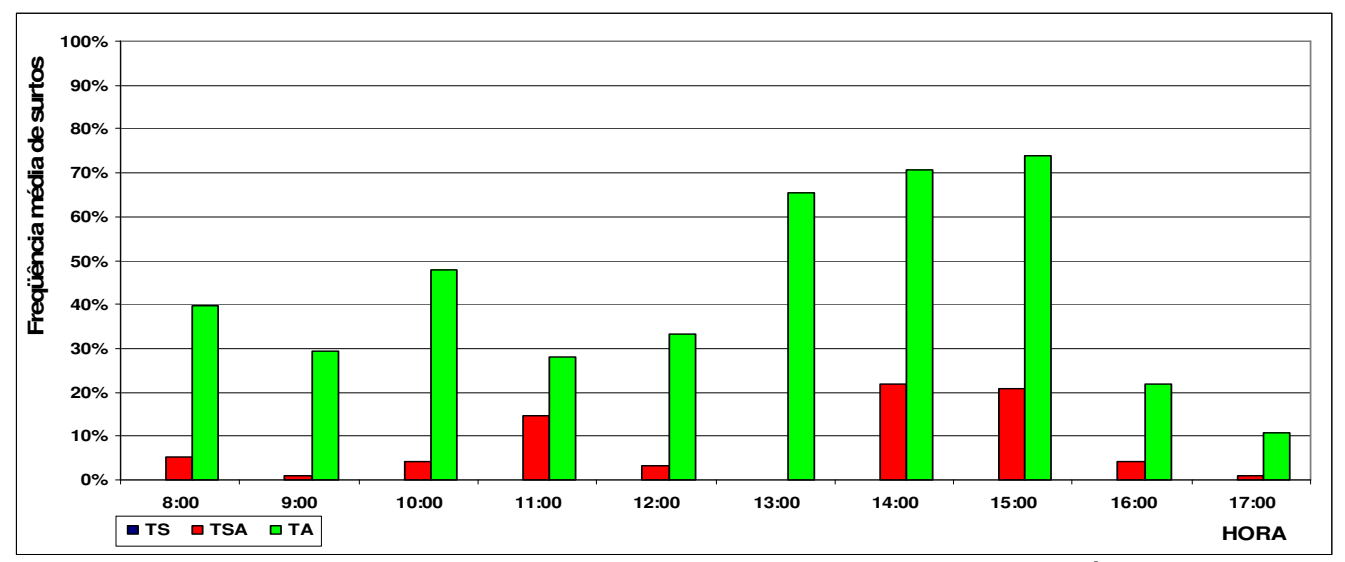

Figura 11 - Distribuição horária da freqüência de surtos da posição "Na Água" (média de cada tratamento)

A freqüência com que os animais permaneceram em pé deu-se de maneira diferente para os tratamentos TS, TSA e TA. No entanto, houve correlação significativa entre os animais dentro de um mesmo tratamento. A distribuição horária das freqüências médias de permanência dos animais em pé para cada tratamento apresenta-se na Figura 12.

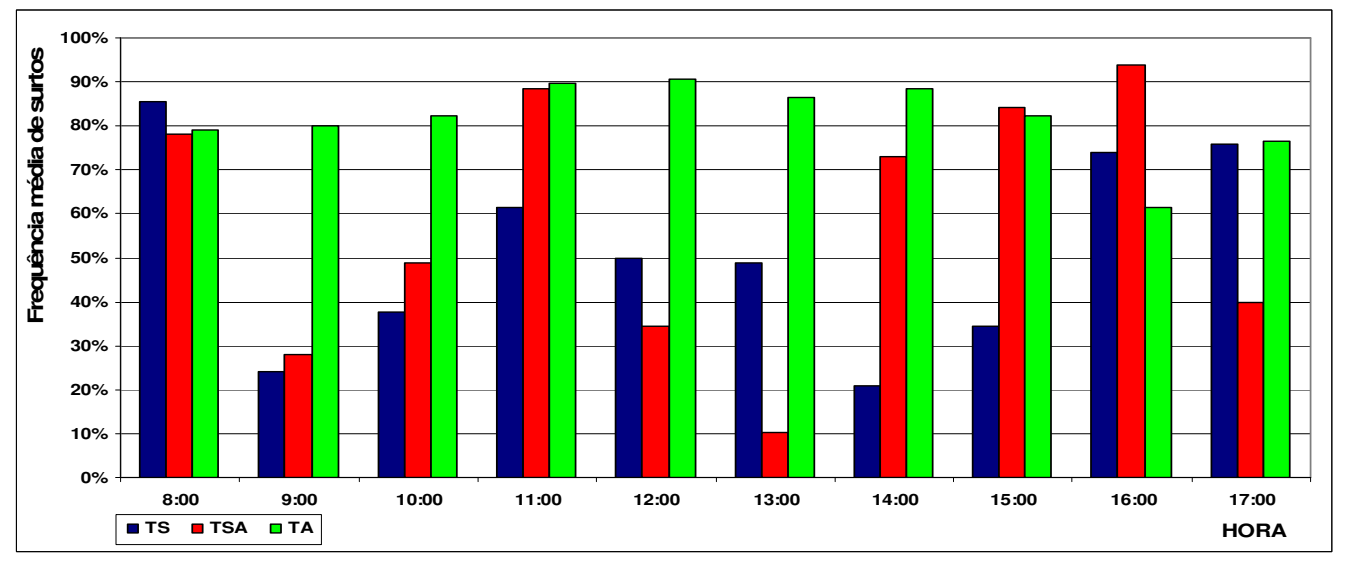

Figura 12 - Distribuição horária da freqüência de surtos da postura "Em Pé" (média de cada tratamento)

A distribuição horária das freqüências médias de permanência dos animais deitados para cada tratamento pode ser observada na Figura 13. A freqüência com que os animais permaneceram deitados deu-se de maneira diferente para os tratamentos TS, TSA e TA. No entanto, houve correlação significativa entre os animais dentro de um mesmo tratamento. 


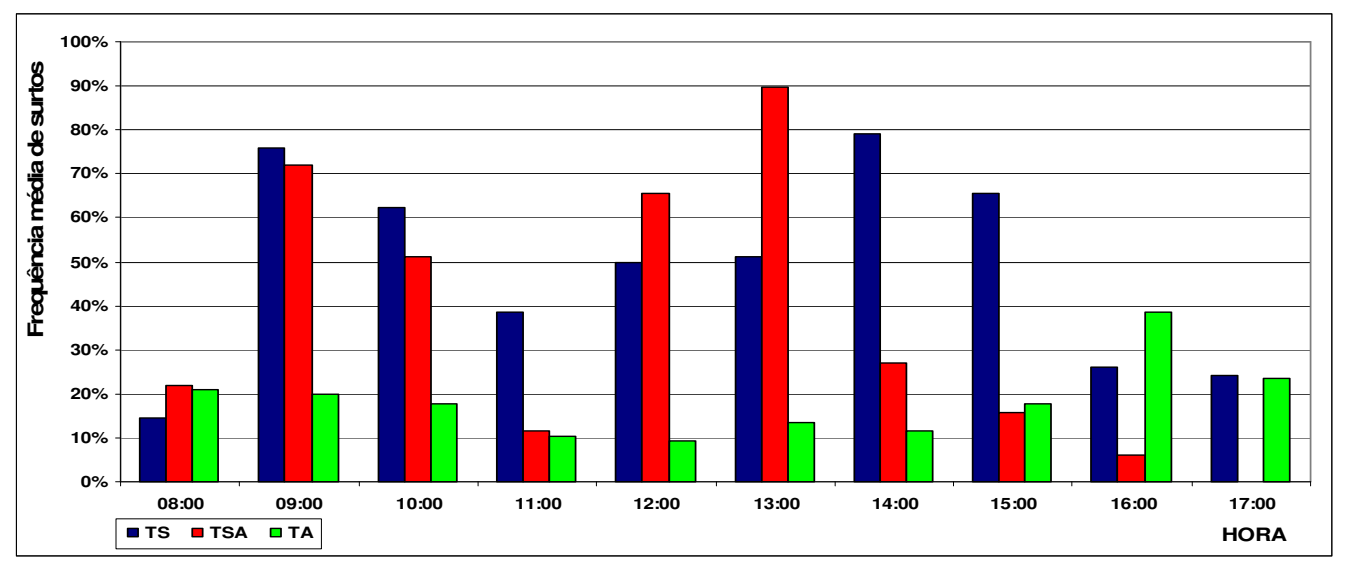

Figura 13 - Distribuição horária da freqüência de surtos da postura "Deitado" (média de cada tratamento)

A freqüência da atividade de pastejo deu-se de maneira diferente para os tratamentos TS, TSA e TA. No entanto, houve correlação significativa entre os animais dentro de um mesmo tratamento. $\mathrm{O}$ animal A4 apresentou freqüência temporal ao acaso, para a atividade de pastejo no tratamento TA. A distribuição horária encontra-se na Figura 14.

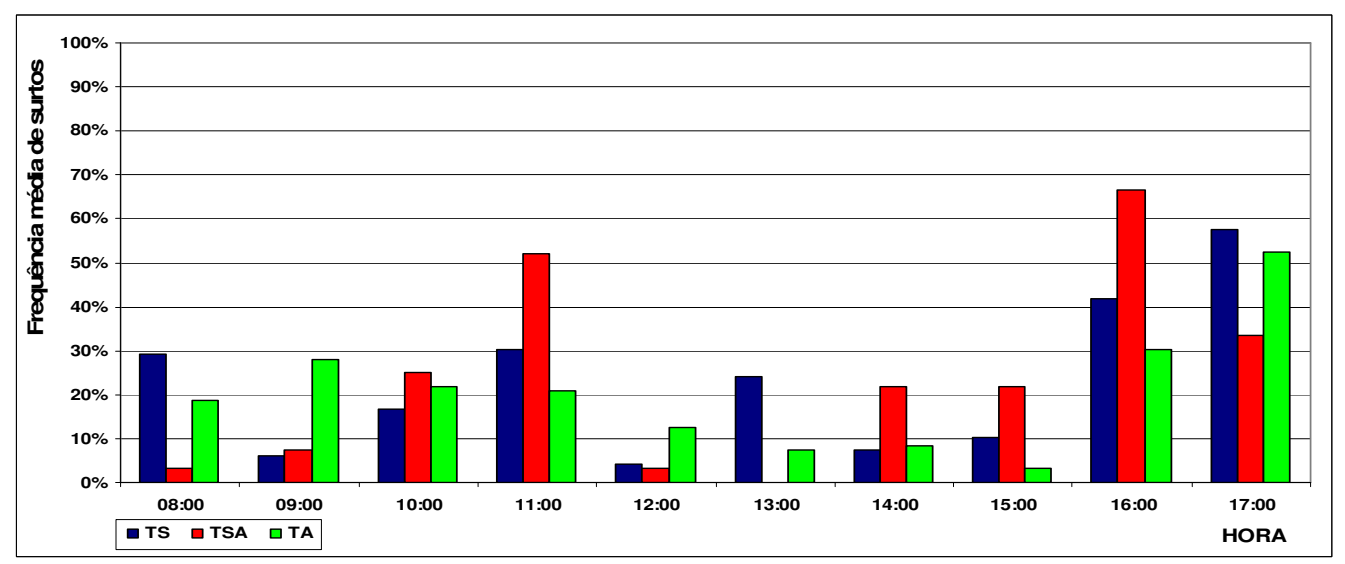

Figura 14 - Distribuição horária da freqüência de surtos da atividade "Em Pastejo" (média de cada tratamento)

A distribuição horária das freqüências médias da atividade de ruminação para cada tratamento está demonstrada na Figura 15. Esta atividade evoluiu de maneira diferente para os tratamentos TS, TSA e TA. No entanto, houve correlação significativa entre os animais dentro do tratamento TSA, o que não ocorreu para os demais tratamentos. 


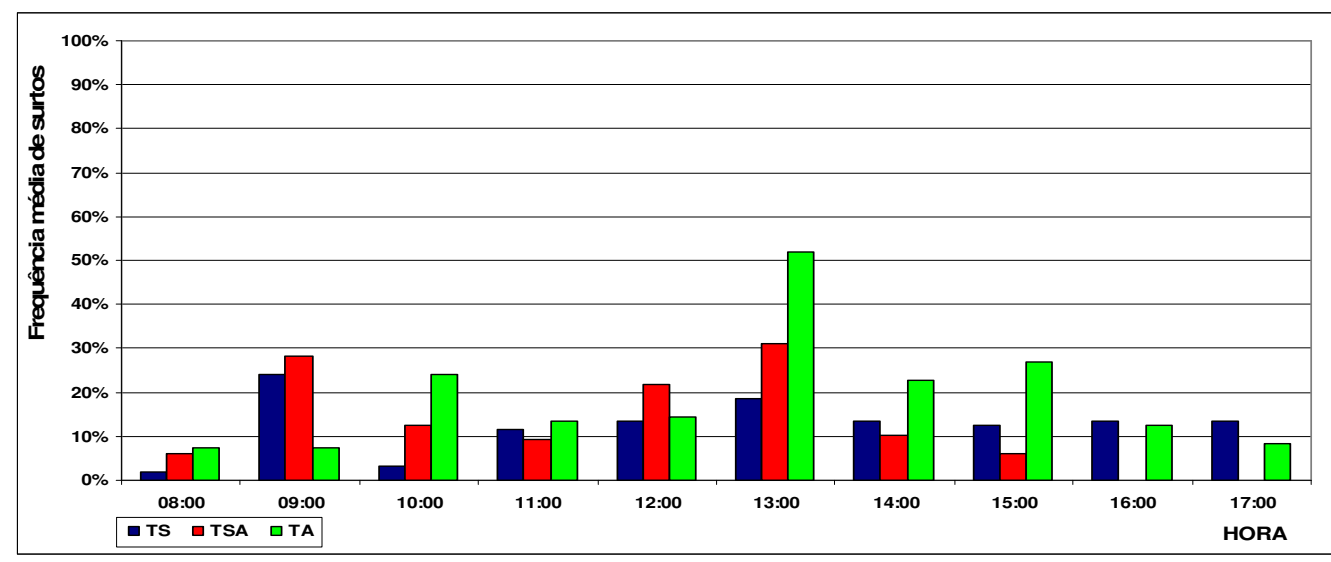

Figura 15 - Distribuição horária da freqüência de surtos da atividade "Em Ruminação" (média de cada tratamento)

A freqüência da atividade de deslocamento desenvolveu-se de maneira diferente para os tratamentos TS, TSA e TA. Houve correlação significativa entre os animais dentro do tratamento TS e do TSA, o que não ocorreu para o tratamento TA. A distribuição horária é apresentada na Figura 16.

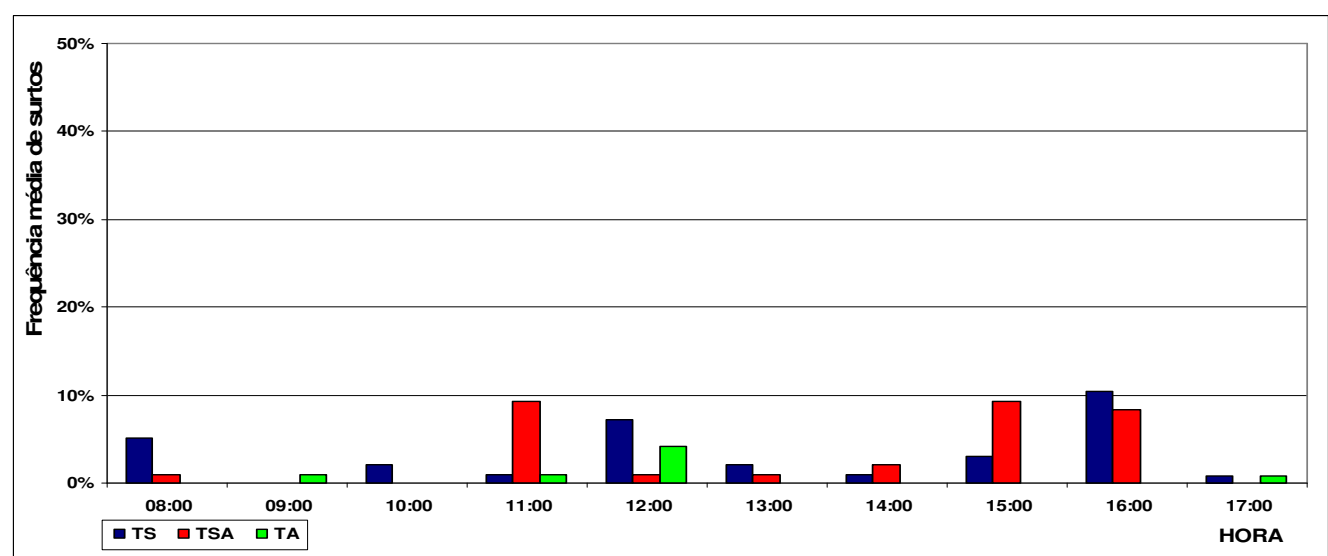

Figura 16 - Distribuição horária da freqüência de surtos da atividade "Em Deslocamento" (média de cada tratamento)

A freqüência da atividade de permanência em ócio não se assemelhou entre os tratamentos TS, TSA e TA. No entanto, houve correlação significativa entre os animais dentro de um mesmo tratamento. A distribuição horária das freqüências médias da atividade de permanência em ócio para cada tratamento pode ser observada na Figura 17. 


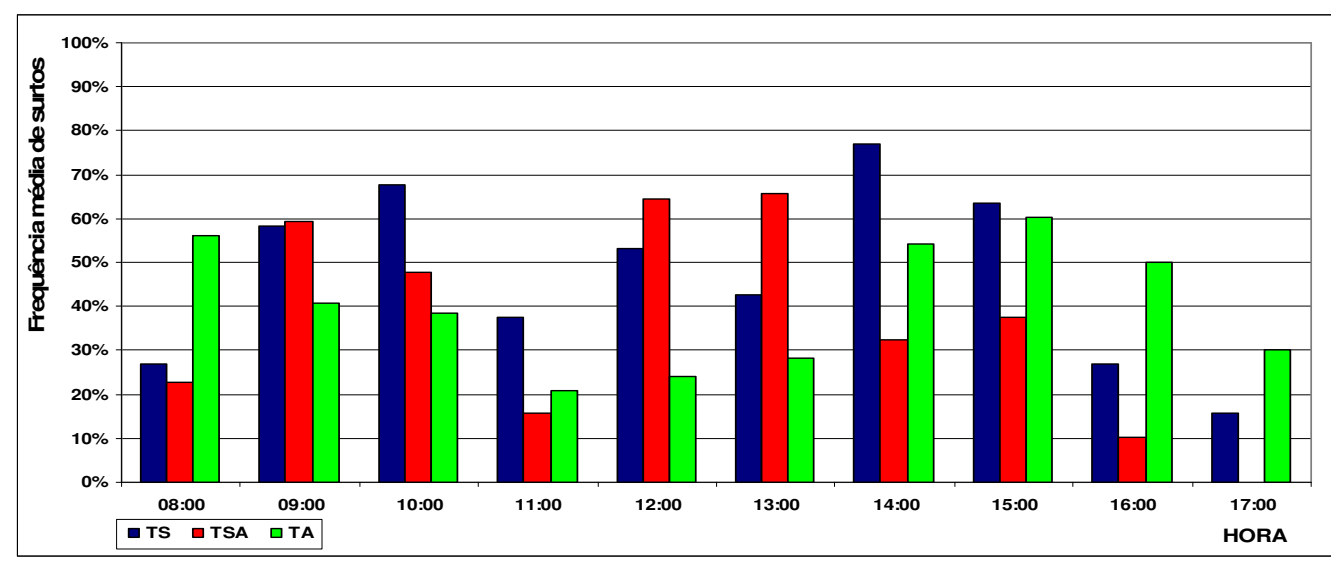

Figura 17 - Distribuição horária da freqüência de surtos da atividade "Em Ócio" (média de cada tratamento)

A freqüência de outras atividades deu-se de maneira diferente para os tratamentos TS, TSA e TA, mas houve correlação significativa entre os animais dentro de um mesmo tratamento. A distribuição horária das frequências médias de outras atividades para cada tratamento encontra-se na Figura 18.

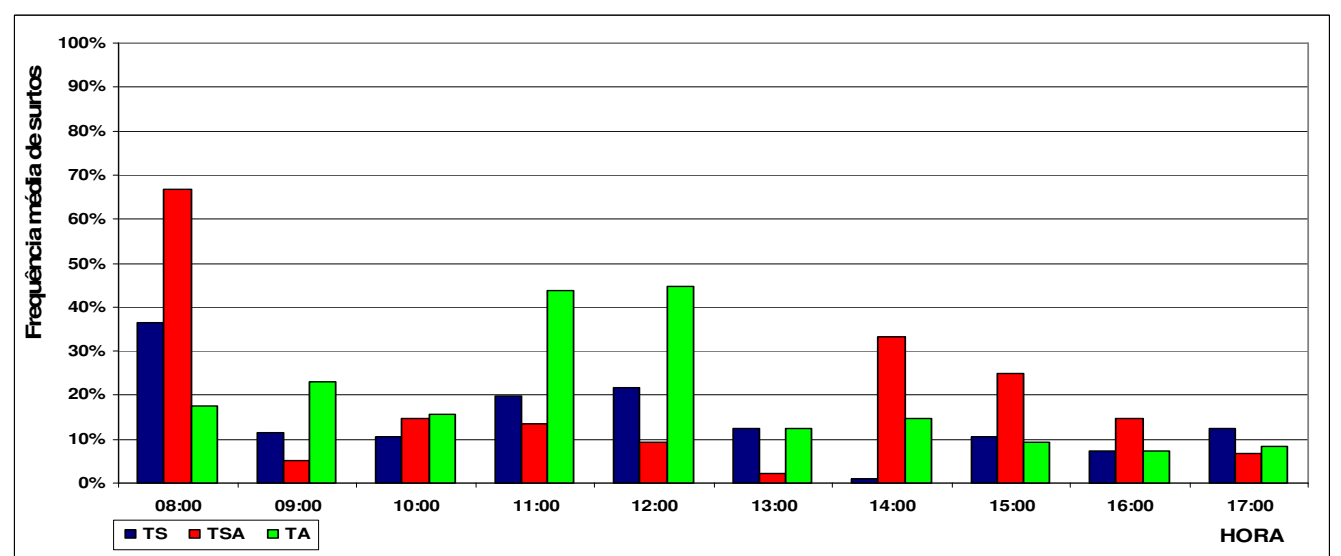

Figura 18 - Distribuição horária da freqüência de surtos de "Outras Atividades" (média de cada tratamento)

A árvore gerada (dendriograma) para tratamento TS, mostrou uma divisão dos animais em dois grupos: o primeiro grupo é formado pelos animais $6,5,4$ e 3 , e o segundo grupo, pelos animais $8,7,2$ e 1. A representação gráfica é apresentada na Figura 19. 


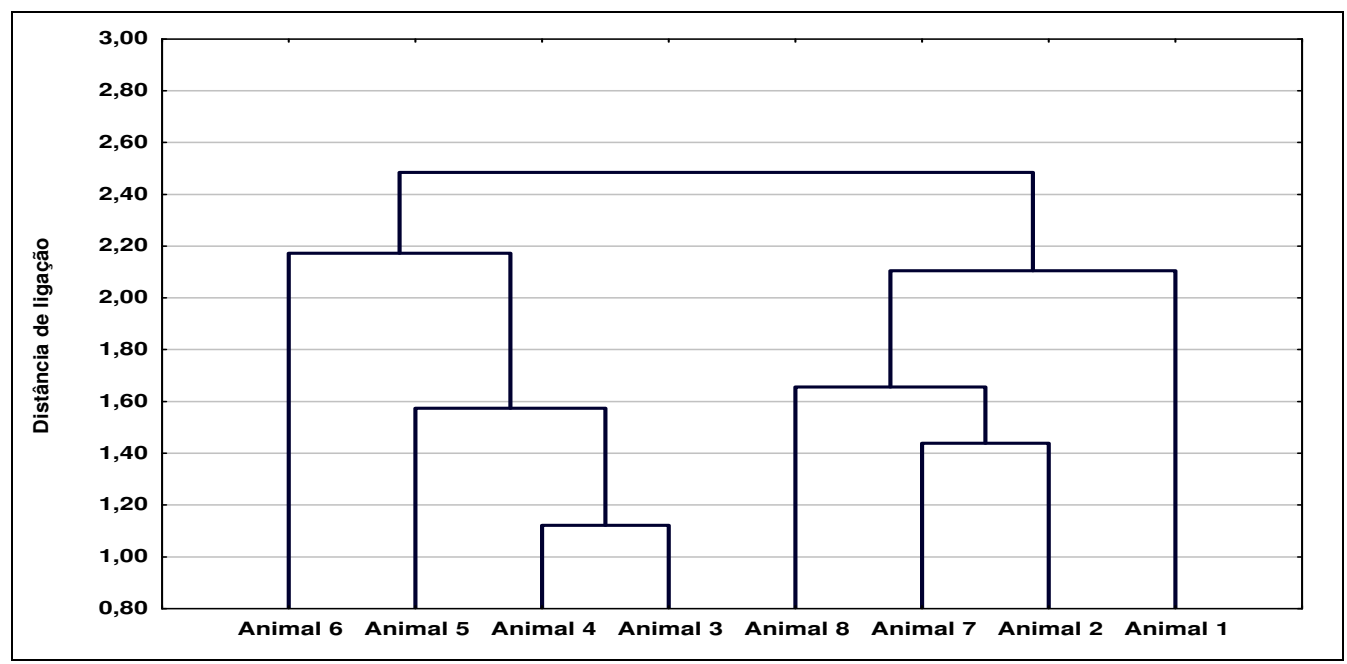

Figura 19 - Dendriograma da análise multivariada de conglomerados com ligação completa para o tratamento TS

No dendriograma obtido para o tratamento TSA, formaram-se três grupos: o primeiro grupo é formado pelos animais 8, 3, 5, 7 e 2; o segundo, pelos animais 4 e 1 , e o terceiro pelo animal 6 . A representação gráfica é apresentada na Figura 20.

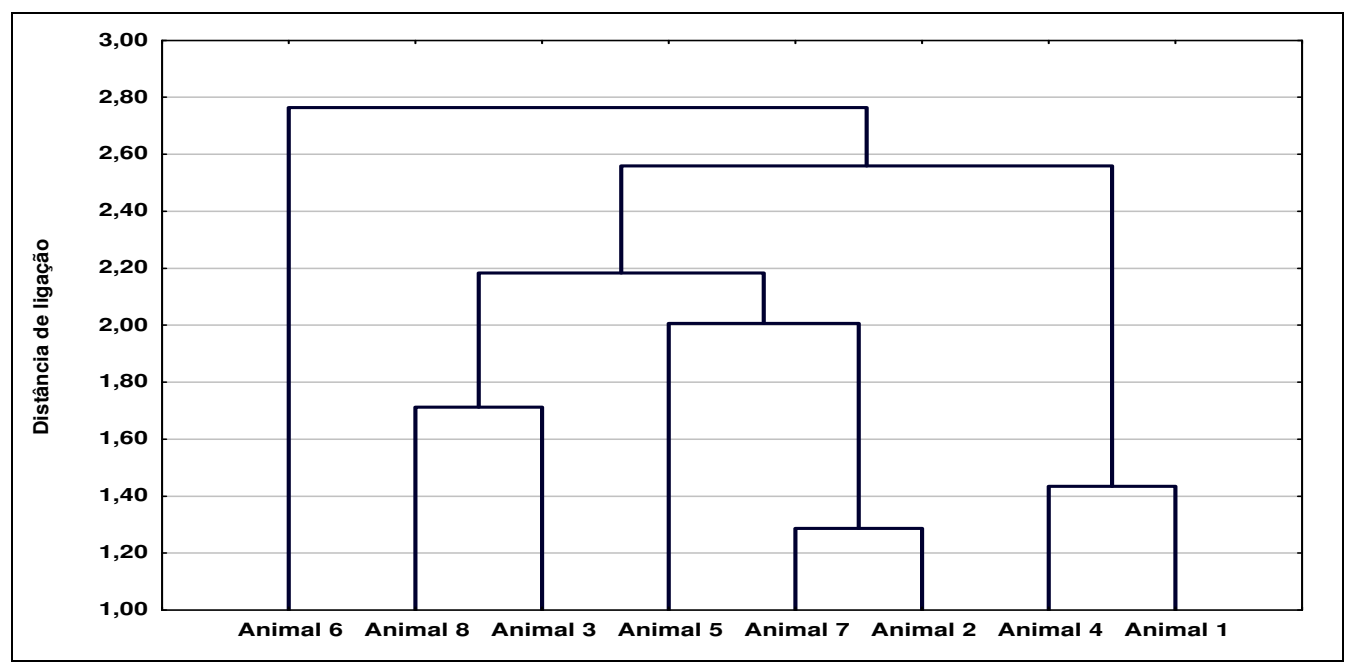

Figura 20 - Dendriograma da análise multivariada de conglomerados com ligação completa para o tratamento TSA

$\mathrm{Na}$ análise de conglomerados com ligação simples do tratamento TA, obteve-se um dendriograma que apresentou uma divisão dos animais em três grupos: o primeiro grupo é formado pelos animais $8,7,6$ e 3 , o 
segundo, pelos animais 2,5 e 1 , e o terceiro pelo animal 4. A representação gráfica é apresentada na Figura 21.

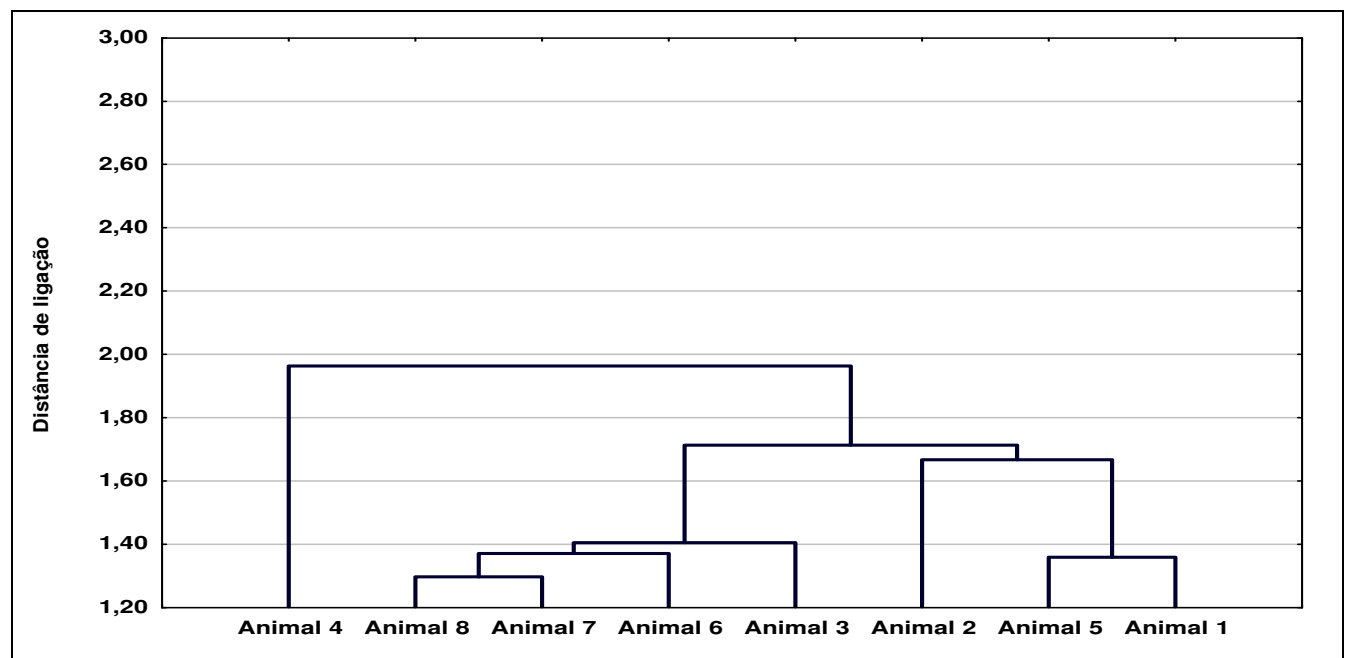

Figura 21 - Dendriograma da análise multivariada de conglomerados com ligação simples para o tratamento TA

A análise de conglomerados que levou em consideração os tratamentos TS, TSA e TA simultaneamente, gerou uma árvore que apresenta uma divisão dos animais em três grupos: o primeiro grupo é formado pelos animais 8, 3, 7 e 2, o segundo pelos animais 5 e 1 e o terceiro, pelos animais 6 e 4 . A representação gráfica é apresentada na Figura 22.

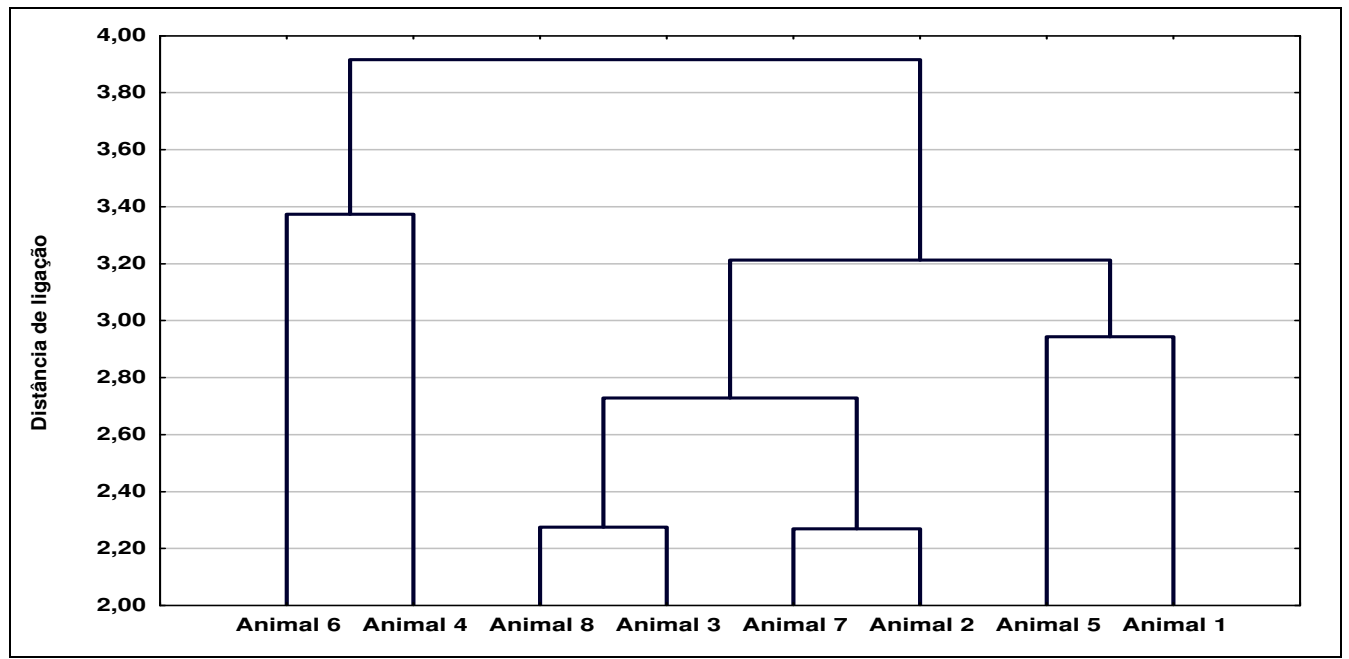

Figura 22 - Dendriograma da análise multivariada de conglomerados com ligação completa para os tratamentos TS, TSA e TA 


\section{DISCUSSÃO}

\subsection{Desempenho dos animais}

O ganho de peso médio diário dos animais durante todo o período experimental foi de $855 \mathrm{~g}$, sendo que os animais com pelagem longa obtiveram um ganho de $660 \mathrm{~g} /$ dia e, para os animais com pelagem curta, o ganho foi de $1.050 \mathrm{~g} / \mathrm{dia}$, para o mesmo período. Embora esse desempenho seja referente somente ao período experimental (20 dias), observou-se que os animais de pelagem curta têm vantagem na ingestão de alimentos, fato este facilitado provavelmente pela maior eficiência na termólise a partir da mais rápida evaporação do suor e maior convecção do ar com a superfície corporal, conforme constatado também por Findlay (1950); Baccari et al. (1984); Silanikove (1992, 2000) e Titto (1996 e 1998).

\subsection{Variáveis climáticas}

Para o período de observação comportamental (entre 8h00 e 18h00), as temperaturas do ar mais altas ocorreram no período das $15 \mathrm{~h} 00$ (média de $32,0^{\circ} \mathrm{C}$ para ambos os tratamentos) e as mais baixas às 8h00 (média de $22,5^{\circ} \mathrm{C}$ para TS e TSA, e $24,0^{\circ} \mathrm{C}$ para TA).

Os maiores registros das umidades relativas do ar para o período de observação experimental ocorreram ao amanhecer (às 8 h00 os valores médios foram de $85 \%$ para os tratamentos TSA e TA, e 70\% para TS) e as mais baixas entre as $14 \mathrm{~h} 00$ e $15 \mathrm{~h} 00$ (55\% para TSA e TA, e 40\% para TS). Para esta variável climática o tratamento TS apresentou valores inferiores 
(em média) quando comparado aos tratamentos TSA e TA. O tratamento TS apresentou valores mais elevados para as velocidades do ar.

Os valores mais elevados encontrados para a radiação global deram-se entre as $11 \mathrm{~h} 00$ e as $12 \mathrm{h00}$, no entanto, vários picos de radiação solar elevada apresentaram-se durante as diferentes horas dos dias de observação comportamental. Os maiores registros das TGNs deram-se entre $14 \mathrm{~h} 30$ e $15 \mathrm{~h} 30$, cerca de $46,5^{\circ} \mathrm{C}$ (TSA e TA) e 45, $0^{\circ} \mathrm{C}$ (TS) para a TGN ao sol, e 37,0ㄷ para a TGN à sombra.

Para o ITGU os maiores registros (aproximadamente 96 para TSA e TA, e 92 para TS) deram-se entre $14 \mathrm{~h} 30$ e $15 \mathrm{~h} 30$.

Durante os dias de observação do período experimental não houve pluviosidade. De maneira geral, pode-se afirmar que todas as variáveis climáticas mostraram-se homogêneas entre os dias de observação de cada tratamento, e que foram significativamente correlacionadas entre os tratamentos (com exceção da velocidade do ar), além disso, as diferenças nos valores das variáveis climáticas dos diferentes tratamentos não pareceram ser biologicamente significativas, especialmente para os valores das temperaturas do ar; assim, pode-se afirmar que os 9 dias utilizados para observação e obtenção dos dados comportamentais foram climaticamente muito parecidos.

\subsection{Comportamento}

Observa-se que a ocorrência da posição dos animais ao sol diminuiu consideravelmente das $12 \mathrm{h00}$ às $14 \mathrm{~h} 00$, para todos os tratamentos, especialmente no período das $13 \mathrm{~h} 00$ do tratamento TSA, onde nenhum animal encontrava-se ao sol (neste período o ITGU foi superior a 95). O aumento da ocorrência de animais ao sol iniciou-se a partir das 16h00, provavelmente pela diminuição da temperatura do ar após este horário. A temperatura do ar influencia (favorecendo ou não) as atividades de ingestão de nutrientes e a ruminação, determinadas pelo metabolismo energético e pela própria fisiologia digestiva. 
O pastejo foi a principal atividade realizada ao sol, concentrado particularmente nos horários menos quentes do dia: no início do dia e após as 16h00, além de um período de pastejo intermediário, das 10 h00 às $11 \mathrm{~h} 00$, antes das horas mais quentes do dia. A atividade de pastejo dos animais apresentou resultados análogos às afirmações de Hafez (1973), Hodgson (1990), Blackshaw \& Blackshaw (1994) e Fraser \& Broom (1997) que concluem que os bovinos pastejam de maneira mais contínua no começo da manhã e final da tarde, pois as temperaturas são mais amenas, evitando alimentarem-se durante as horas mais quentes do dia. A diminuição da atividade de pastejo está diretamente relacionada à redução do ganho de calor pela digestão e pela atividade muscular, fato este ressaltado nas horas mais quentes do dia, onde os animais procuram pela sombra como resposta ao estresse térmico pelo calor, conforme as colocações de Findlay (1950), Hafez (1973), Fraser \& Broom (1997) e Silanikove (2000).

O recurso de sombreamento foi utilizado com freqüência nos seguintes períodos: das 8 h00 às 15 h00 para TS (a freqüência média de surtos de posicionamento sob a sombra foi de 75\%), das 8 h00 às $14 \mathrm{~h} 00$ para TSA (com um pico entre $12 \mathrm{h00}$ e $13 \mathrm{~h} 00$ - freqüência maior que 90\%) e no período das 12 h00 para TA (sombra do cocho de suplementação). Os animais do tratamento TSA, notadamente preferiram utilizar 0 sombreamento como recurso de defesa contra o calor, o que pode ser indicativo da melhor termólise dos bovinos quando sob a sombra, através da sudação e da convecção, não acumulando assim excesso de água no pelame, e até mesmo pela própria condição evolutiva da espécie, em seus aspectos comportamentais e anatômicos. Ao comparar a espécie bovina com a bubalina, observa-se que a primeira apresenta sua pele uniformemente coberta por pêlos, o que representa uma barreira física aos processos de condução para a água quando imersos e à evaporação da mesma após emergirem. Apesar disso, usando preferencialmente o recurso de sombreamento, os bovinos também se utilizaram (no tratamento TSA) do recurso de água para imersão com menor freqüência. As atividades 
mais recorrentes realizadas sob a sombra foram na postura deitada: ruminação e ócio. Observou-se que os animais também procuraram a sombra em horários com menor predominância de radiação solar, comportamento este também observado por Paranhos da Costa \& Cromberg (1997).

O recurso de água para imersão foi utilizado com freqüência nos seguintes períodos: das $14 \mathrm{~h} 00$ às $15 \mathrm{~h} 00$ para TSA (observou-se um pico também às $11 \mathrm{~h} 00$ ) e das $8 \mathrm{~h} 00$ às $15 \mathrm{~h} 00$ para TA (com picos das $13 \mathrm{~h} 00$ às $15 \mathrm{~h} 00$ - freqüência maior que 65\%). O comportamento dos animais no tratamento TA demonstrou que na ausência da sombra (ou mesmo quantidade insuficiente de sombra) a espécie bovina busca a imersão em água, quando disponível, para minimizar o estresse térmico pelo calor, favorecendo assim a termólise por condução e evaporação, apesar de permanecerem em pé. Os animais 4 e 1 foram os que mais utilizaram o recurso de água para imersão, sendo também os animais que apresentaram o maior comprimento na pelagem, com $3 \mathrm{~cm}$ e 2,5 cm, respectivamente. Assim como no uso do recurso de sombreamento, as atividades mais recorrentes quando dos animais na água, foram o ócio e a ruminação, no entanto, sempre na postura em pé.

Os bovinos também optam por utilizar o recurso de água para imersão contra o estresse causado pelo calor, no entanto, não o utilizaram com a mesma freqüência que o recurso de sombreamento. Este comportamento é ocasionado provavelmente pelo fato da água aumentar a perda de calor da pele do animal via condução, e por funcionar de maneira sinérgica com a vasodilatação periférica pois, segundo Findlay (1950), a pele dos bovinos é um importante meio para a dissipação do calor por condução. Além da perda por condução, há um incremento da perda de calor endógeno devido ao efeito da evaporação da água da pele molhada do animal, fato este ressaltado por Titto et al. (1996) e McFarland (1999).

Nas análises multivariadas, o dendriograma obtido no tratamento TS observado na Figura 19 no item 4.1, mostrou uma divisão dos animais em dois grupos: o primeiro grupo é formado pelos animais $6,5,4$ e 3 , que 
apresentaram maior tempo de permanência deitados e em ócio, diminuindo assim a atividade de deslocamento e utilizando com maior freqüência o recurso de sombreamento (menor permanência ao sol), além de serem, na sua maioria, os animais mais pesados e que possuíam maior comprimento de pelagem (com exceção do animal 6 que possuía pêlos curtos). Os animais do segundo grupo $(8,7,2$ e 1) possuíam pelagem curta (com exceção do animal 1) e permaneceram mais ao sol, em pé e pastejando. A provável explicação para o posicionamento do animal 6, é que, além de ser um animal com alto peso corporal, teve um comportamento muito semelhante ao do primeiro grupo, mesmo tendo pelagem curta, o que contribuiu com sua maior distância de ligação com os outros animais do seu conglomerado. Este fato explica porque ele foi o último animal a ser anexado ao seu grupo, o que também pode ser observado para o animal 1 do segundo grupo, que possuía pelagem longa, contra a pelagem curta dos outros animais do grupo.

No dendriograma obtido para o tratamento TSA, apresentado na Figura 20 do item 4.1, observa-se uma divisão dos animais em três grupos: o primeiro grupo é formado pelos animais 8, 3, 5, 7 e 2, o segundo, pelos animais 4 e 1 , e o terceiro pelo animal 6. Os animais do primeiro grupo (60\% com pêlos curtos) utilizaram o recurso de água para imersão e de sombreamento poucas vezes (média de 61 surtos de utilização de sombreamento e de 7 surtos de utilização do recurso de água para imersão) e na sua grande maioria permaneceram ao sol e em atividade de pastejo. Os animais do segundo grupo, utilizaram com maior freqüência o recurso de água para imersão, permanecendo em pé e em atividade intensa de ruminação, além de serem ambos de pelagem longa. $O$ animal 6 utilizou mais o recurso de sombreamento, permanecendo deitado e em atividade de ruminação ou ócio. Os animais 4, 1 e 6 apresentam maior distância de ligação com os animais do primeiro grupo pois mostraram menor atividade de pastejo e menor posicionamento ao sol.

Para a análise de conglomerados com ligação simples do tratamento TA obteve-se uma árvore que apresentou uma divisão dos animais em três 
grupos: o primeiro grupo é formado pelos animais 8, 7, 6 e 3, o segundo, pelos animais 2, 5 e 1, e o terceiro pelo animal 4. Os animais do primeiro grupo (75\% com pêlos curtos) optaram por permanecer sob a sombra projetada do cocho de suplementação, utilizando pouco o recurso da água para imersão. A proximidade de ligação dos animais do segundo grupo com os do primeiro é devida às semelhanças na utilização dos recursos de sombreamento (maior que o uso da água para imersão) e por permanecerem grande parte do tempo deitados, no entanto, diferem pelas freqüências das atividades de ruminação e deslocamento (maiores para os animais do primeiro grupo). O animal 4 teve um comportamento diferente dos outros dois grupos, pois utilizou mais o recurso de água para imersão, pastejando muito pouco, além de apresentar pelagem longa. A ligação do conglomerado representado pelos animais 8,7 e 6 com o animal 3 é próxima devido à semelhança nos pesos corporais, no uso dos recursos de sombreamento (sombra projetada do cocho) e água para imersão, mesmo tendo comprimentos de pêlo diferentes. O animal 2 aproxima-se do primeiro grupo pela similaridade de seu peso corporal (mais alto que o dos animais 5 e 1), comprimento de pêlo (curto) e alta freqüência na atividade de pastejo. Vale ressaltar que todos os animais utilizaram o recurso de água para imersão.

$\mathrm{Na}$ análise de conglomerados que levou em consideração os tratamentos TS, TSA e TA simultaneamente, foi obtida uma árvore que apresenta uma divisão dos animais em três grupos: o primeiro grupo é formado pelos animais 8, 3, 7 e 2 (sendo 75\% com pelagem curta), que utilizaram menos os recursos disponibilizados nos tratamentos (sombra e água para imersão), apresentando freqüência de atividade de ruminação semelhantes, pastejando mais que os animais do segundo (5 e 1) e terceiro (6 e 4) grupos. Por possuírem maior comprimento de pêlo, menor peso corporal e maior utilização do recurso de sombreamento que os animais do primeiro grupo, os animais 5 e 1 se associaram no segundo grupo. Os animais que formam o terceiro grupo, assemelham-se por ficarem menos ao sol (pastejando menos) e por utilizarem mais os recursos disponíveis - 
sombreamento para 0 animal $6 \mathrm{em}$ ambos os tratamentos, e sombreamento (tratamento TS) e água para imersão (tratamentos TSA e TA) para o animal 4 - mas, apresentam grande distância de ligação entre si por diferirem no comprimento da pelagem e pela diferença na opção pelo recurso utilizado, fato este que os distancia também dos demais grupos.

De maneira geral, observa-se que os animais com menor comprimento de pêlos (incluindo o animal de pelagem negra) utilizaram menos os recursos de perda de calor que os animais de pelagem longa.

As análises das séries temporais mostraram que o comportamento dos animais não foi casual. A provável explicação para este acontecimento é que as variáveis climáticas influenciam sobremaneira na decisão do animal acerca do que fazer em dada circunstância, fazendo escolhas baseadas na avaliação do ambiente, escolhas estas também relatadas por Paranhos da Costa (2000). Quando observado o comportamento geral dos animais, os tratamentos que tinham disponibilidade de água para imersão ocasionaram uma maior permanência dos animais ao sol, sendo que em média os animais quando no tratamento TA permaneceram mais ao sol que os animais nos tratamentos TSA e TS, e que os animais de TSA ficaram mais ao sol que quando presentes no tratamento TS.

No entanto, o tratamento TS foi mais quente no período das $12 \mathrm{~h} 30$ às $15 \mathrm{~h} 00$, com a menor umidade relativa (o que favoreceria a perda de calor por evaporação), menores TGNs, menor ITGU, além de apresentar a velocidade do ar mais elevada em comparação com os outros tratamentos (o vento pode melhorar a perda de calor por convecção), mesmo assim o comportamento mais recorrente foi o de procura pelo sombreamento, inclusive nos horários menos quentes do dia. A provável explicação para este comportamento é a que a atividade de pastejo só não foi maior pelo fato do pasto ter sido rebaixado rapidamente pelos animais, pois este piquete experimental (tratamento TS) teve um menor tempo de descanso e recuperação (anterior ao início do experimento) em comparação com os outros tratamentos. Assim, a menor oferta de forragem, que aumentaria a competição entre os animais e forçaria um maior tempo de pastejo, 
ocasionou um comportamento de procura pelo recurso de proteção contra o calor, provavelmente na espera de uma melhor opção de horário (diga-se melhores condições climáticas) para o pastejo, ou quando a necessidade de ingestão (fome) exceder o inconveniente climático. Este comportamento foi citado por Poppi et.al. (1996), que atenta para a utilização dos sentidos (visão, paladar, olfato e tato) pelos animais, na avaliação do esforço envolvido na atividade de pastejo, sentidos estes influenciados diretamente pela estrutura do pasto.

Os resultados encontrados mostraram que os bovinos são animais gregários, resultados estes que corroboram com a afirmação de Paranhos da Costa (2000); os 8 animais comportaram-se como um grupo homogêneo, estando este comportamento em consenso com as colocações propostas por Hodgson (1990), que afirma que os animais de um grupo tendem a seguir um padrão de comportamento semelhante; no entanto, foi possível detectar diferenças individuais importantes no uso dos recursos de proteção contra o calor, especialmente no tocante ao comprimento de pêlo dos animais.

Paranhos da Costa \& Cromberg (1997) ressaltam que ao disponibilizar sombra aos animais, facilita-se a termorregulação. Assim, possivelmente com o uso do recurso de sombreamento (ou de água para imersão) nas horas mais quentes do dia, onde a radiação solar é intensa, os animais Angus adaptaram suas reações termorregulatórias de acordo com as condições ambientais. Os bovinos de origem européia apresentam vantagens produtivas quando manejados a pasto em regiões de clima tropical, mas utilizam-se, quando necessário, de recursos que proporcionem bem-estar térmico, como o sombreamento e a água para imersão. Além do estresse ocasionado pelas altas temperaturas e radiação solar, observa-se que os animais definitivamente optam por situações que proporcionem conforto e bem-estar, mesmo que momentaneamente, evitando o desconforto. 


\section{CONCLUSÕES}

O presente trabalho permite concluir que:

1) Bovinos da raça Angus com maior comprimento de pêlos têm a termólise prejudicada, procurando os recursos de perda de calor com maior freqüência e intensidade.

2) Os bovinos optam por utilizar o sombreamento como recurso de defesa contra as altas temperaturas do ar e a radiação solar direta.

3) Na ausência de sombreamento, os bovinos da raça Angus podem utilizar a água para imersão como recurso secundário para perda de calor.

4) Em condições de pastejo em climas quentes, recursos de defesa contra o calor são essenciais para a melhoria do bem-estar térmico dos bovinos.

5) O padrão de comportamento dos bovinos da raça Angus é influenciado pelas condições climáticas. 


\section{ANEXO A}

\section{Etograma de Trabalho}

\section{Categorias 1 - Posições}

1. Ao Sol - animal posicionado diretamente sob o sol

2. À Sombra - animal sob a sombra (natural ou artificial), protegido da ação direta do sol

3. Na Água - animal dentro da água (parcial ou totalmente)

\section{Categoria 2 - Posturas}

1. Em Pé

2. Deitado - em decúbito esternal ou lateral

\section{Categoria 3 - Atividades}

1. Em Pastejo - recolhendo a pastagem com a boca e ingerindo-a

2. Em Ruminação - fazendo movimentos de mastigação

3. Em Deslocamento - caminhando com ou sem pausa por 5 minutos, sem ruminar ou pastejar

4. Em Ócio - sem atividade aparente, sem movimentação

5. Outras Atividades - quaisquer atividades que não se deslocar, pastejar ou ruminar. Por exemplo, ingerir sal, beber água, interagir com os outros animais 


\section{ANEXO B}

\section{Comportamento de bovinos a pasto}

DIA \& MÊS

TRATAMENTO:

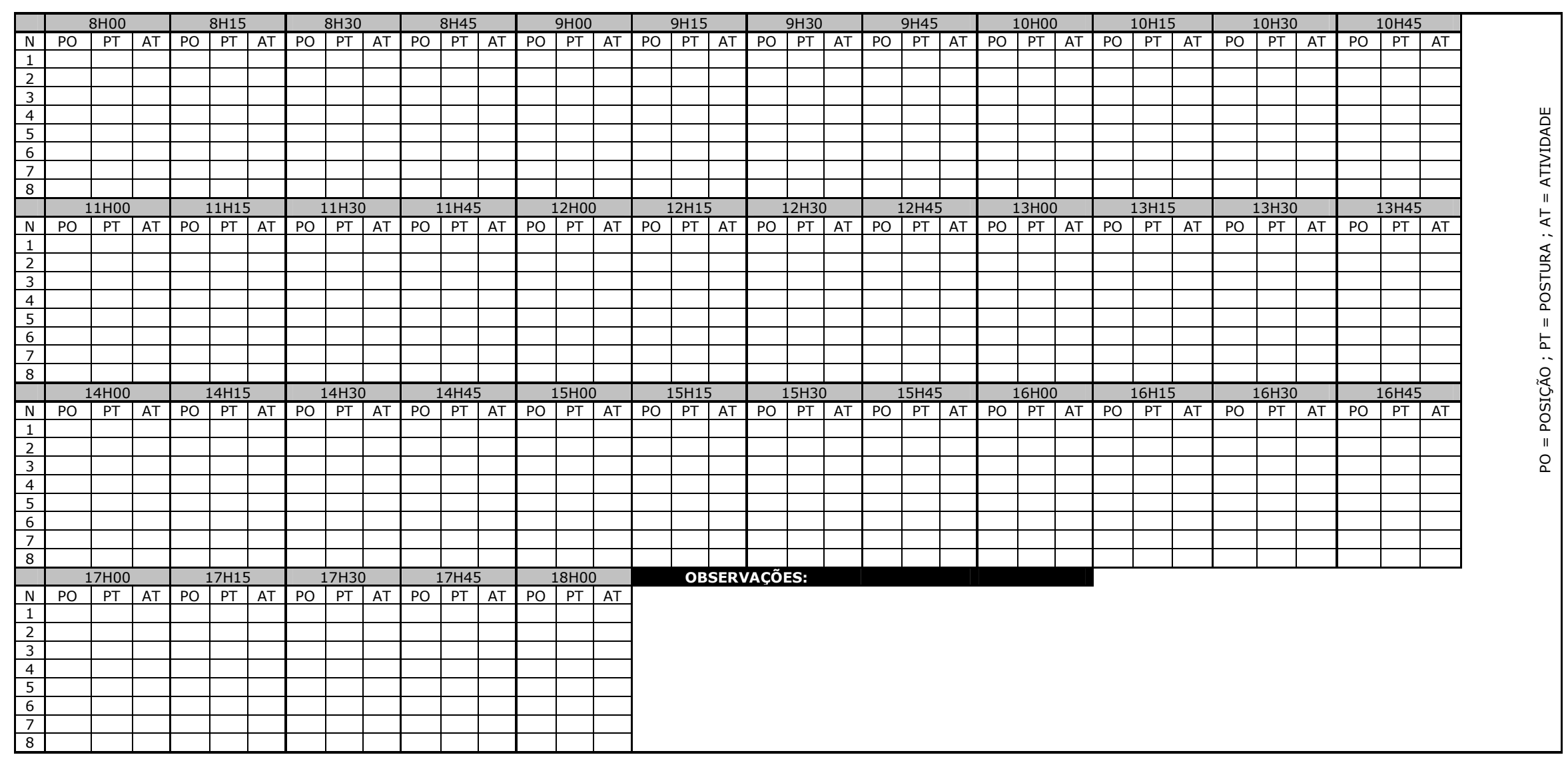




\section{ANEXO C}

Tabela 3. - Correlações entre as temperaturas do ar para os diferentes dias do experimento valores em vermelho são significativos $(p<0,05)$ - (Pirassununga - SP, 2002)

\begin{tabular}{|c|c|c|c|c|c|c|c|c|c|}
\hline & $\mathrm{TS}^{7}{ }^{7}$ & TS2 $^{7}$ & TS3 $^{7}$ & TSA1 $^{7}$ & TSA2 $^{7}$ & TSA3 $^{7}$ & TA1 $^{7}$ & TA2 $^{7}$ & TA3 $^{7}$ \\
\hline TS1 & & 0,95 & 0,72 & 0,95 & 0,65 & 0,93 & 0,79 & 0,69 & 0,84 \\
\hline TS2 & & & 0,80 & 0,95 & 0,79 & 0,97 & 0,88 & 0,80 & 0,76 \\
\hline TS3 & & & & 0,78 & 0,86 & 0,80 & 0,84 & 0,86 & 0,38 \\
\hline TSA1 & & & & & 0,77 & 0,96 & 0,87 & 0,80 & 0,76 \\
\hline TSA2 & & & & & & 0,83 & 0,96 & 0,98 & 0,31 \\
\hline TSA3 & & & & & & & 0,92 & 0,84 & 0,72 \\
\hline TA1 & & & & & & & & 0,96 & 0,49 \\
\hline TA2 & & & & & & & & & 0,37 \\
\hline TA3 & & & & & & & & & \\
\hline
\end{tabular}

Tabela 4. - Correlações entre as umidades relativas do ar para os diferentes dias do experimento - valores em vermelho são significativos $(p<0,05)$ - (Pirassununga - SP, 2002)

\begin{tabular}{|c|c|c|c|c|c|c|c|c|c|}
\hline & TS1 & TS2 & TS3 & TSA1 & TSA2 & TSA3 & TA1 & TA2 & TA3 \\
\hline TS1 & & 0,92 & 0,53 & 0,95 & 0,63 & 0,83 & 0,79 & 0,24 & 0,66 \\
\hline TS2 & & & 0,52 & 0,96 & 0,75 & 0,89 & 0,86 & 0,39 & 0,57 \\
\hline TS3 & & & & 0,52 & 0,82 & 0,72 & 0,75 & 0,73 & 0,08 \\
\hline TSA1 & & & & & 0,68 & 0,85 & 0,80 & 0,30 & 0,65 \\
\hline TSA2 & & & & & & 0,87 & 0,94 & 0,86 & 0,15 \\
\hline TSA3 & & & & & & & 0,92 & 0,61 & 0,46 \\
\hline TA1 & & & & & & & & 0,73 & 0,30 \\
\hline TA2 & & & & & & & & & $-0,09$ \\
\hline TA3 & & & & & & & & & \\
\hline
\end{tabular}

Tabela 5. - Correlações entre as radiações globais para os diferentes dias do experimento valores em vermelho são significativos $(p<0,05)$ - (Pirassununga - SP, 2002)

\begin{tabular}{|c|c|c|c|c|c|c|c|c|c|}
\hline & TS1 & TS2 & TS3 & TSA1 & TSA2 & TSA3 & TA1 & TA2 & TA3 \\
\hline TS1 & & 0,84 & 0,70 & 0,83 & 0,91 & 0,67 & 0,82 & 0,89 & 0,54 \\
\hline TS2 & & & 0,73 & 0,62 & 0,82 & 0,68 & 0,71 & 0,71 & 0,46 \\
\hline TS3 & & & & 0,55 & 0,63 & 0,54 & 0,61 & 0,54 & 0,35 \\
\hline TSA1 & & & & & 0,81 & 0,71 & 0,74 & 0,84 & 0,51 \\
\hline TSA2 & & & & & & 0,72 & 0,74 & 0,86 & 0,53 \\
\hline TSA3 & & & & & & & 0,53 & 0,64 & 0,57 \\
\hline TA1 & & & & & & & & 0,82 & 0,46 \\
\hline TA2 & & & & & & & & & 0,56 \\
\hline TA3 & & & & & & & & & \\
\hline
\end{tabular}

\footnotetext{
${ }^{7}$ As siglas TS1, TS2 e TS3 referem-se ao $1^{\circ}, 2^{\circ}$ e $3^{\circ}$ dias de observação do tratamento TS, e assim ordenada e sucessivamente para os tratamentos TSA e TA, e serão utilizadas para as demais tabelas
} 
Tabela 6. - Correlações entre as velocidades do ar para os diferentes dias do experimento valores em vermelho são significativos $(p<0,05)$ - (Pirassununga - SP, 2002)

\begin{tabular}{|c|c|c|c|c|c|c|c|c|c|}
\hline & TS1 & TS2 & TS3 & TSA1 & TSA2 & TSA3 & TA1 & TA2 & TA3 \\
\hline TS1 & & 0,63 & 0,31 & 0,37 & 0,24 & $-0,50$ & 0,36 & $-0,35$ & 0,33 \\
\hline TS2 & & & 0,71 & 0,22 & 0,39 & $-0,17$ & 0,04 & $-0,07$ & 0,47 \\
\hline TS3 & & & & 0,16 & 0,59 & 0,07 & $-0,35$ & 0,36 & 0,37 \\
\hline TSA1 & & & & & 0,54 & $-0,60$ & 0,15 & $-0,08$ & $-0,09$ \\
\hline TSA2 & & & & & & $-0,43$ & $-0,17$ & 0,05 & $-0,05$ \\
\hline TSA3 & & & & & & & $-0,55$ & 0,49 & 0,25 \\
\hline TA1 & & & & & & & & $-0,49$ & 0,02 \\
\hline TA2 & & & & & & & & & 0,13 \\
\hline TA3 & & & & & & & & & \\
\hline
\end{tabular}

Tabela 7. - Correlações entre as TGNs ao sol para os diferentes dias do experimento - valores em vermelho são significativos $(p<0,05)$ - (Pirassununga - SP, 2002)

\begin{tabular}{|c|c|c|c|c|c|c|c|c|c|}
\hline & TS1 & TS2 & TS3 & TSA1 & TSA2 & TSA3 & TA1 & TA2 & TA3 \\
\hline TS1 & & 0,97 & 0,94 & 0,89 & 0,86 & 0,92 & 0,88 & 0,91 & 0,92 \\
\hline TS2 & & & 0,94 & 0,90 & 0,93 & 0,97 & 0,87 & 0,93 & 0,93 \\
\hline TS3 & & & & 0,88 & 0,84 & 0,89 & 0,82 & 0,88 & 0,93 \\
\hline TSA1 & & & & & 0,82 & 0,85 & 0,75 & 0,89 & 0,87 \\
\hline TSA2 & & & & & & 0,95 & 0,81 & 0,85 & 0,83 \\
\hline TSA3 & & & & & & & 0,80 & 0,91 & 0,93 \\
\hline TA1 & & & & & & & & 0,75 & 0,76 \\
\hline TA2 & & & & & & & & & 0,86 \\
\hline TA3 & & & & & & & & & \\
\hline
\end{tabular}

Tabela 8. - Correlações entre as TGNs à sombra para os diferentes dias do experimento valores em vermelho são significativos $(p<0,05)$ - (Pirassununga - SP, 2002)

\begin{tabular}{|c|c|c|c|c|c|c|c|c|c|}
\hline & TS1 & TS2 & TS3 & TSA1 & TSA2 & TSA3 & TA1 & TA2 & TA3 \\
\hline TS1 & & 0,99 & 0,97 & 0,96 & 0,95 & 0,99 & 0,95 & 0,95 & 0,95 \\
\hline TS2 & & & 0,98 & 0,95 & 0,94 & 0,98 & 0,95 & 0,97 & 0,96 \\
\hline TS3 & & & & 0,94 & 0,91 & 0,97 & 0,91 & 0,94 & 0,92 \\
\hline TSA1 & & & & & 0,93 & 0,96 & 0,92 & 0,94 & 0,90 \\
\hline TSA2 & & & & & & 0,95 & 0,96 & 0,90 & 0,89 \\
\hline TSA3 & & & & & & & 0,94 & 0,93 & 0,93 \\
\hline TA1 & & & & & & & & 0,94 & 0,89 \\
\hline TA2 & & & & & & & & & 0,96 \\
\hline TA3 & & & & & & & & & \\
\hline
\end{tabular}


Tabela 9. - Correlações entre os índices de temperatura de globo e umidade para os diferentes dias do experimento - valores em vermelho são significativos $(p<0,05)$ - (Pirassununga - SP, 2002)

\begin{tabular}{|c|c|c|c|c|c|c|c|c|c|}
\hline & TS1 & TS2 & TS3 & TSA1 & TSA2 & TSA3 & TA1 & TA2 & TA3 \\
\hline TS1 & & 0,97 & 0,94 & 0,87 & 0,84 & 0,91 & 0,85 & 0,91 & 0,93 \\
\hline TS2 & & & 0,95 & 0,90 & 0,91 & 0,96 & 0,82 & 0,94 & 0,94 \\
\hline TS3 & & & & 0,86 & 0,84 & 0,91 & 0,79 & 0,89 & 0,95 \\
\hline TSA1 & & & & & 0,80 & 0,85 & 0,69 & 0,89 & 0,87 \\
\hline TSA2 & & & & & & 0,93 & 0,76 & 0,85 & 0,83 \\
\hline TSA3 & & & & & & & 0,76 & 0,91 & 0,93 \\
\hline TA1 & & & & & & & & 0,72 & 0,73 \\
\hline TA2 & & & & & & & & & 0,87 \\
\hline TA3 & & & & & & & & & \\
\hline
\end{tabular}

Tabela 10. - Séries temporais com distribuição ao acaso ( $\left.{ }^{a}\right)$ pelo teste de Rayleigh, para os diferentes tratamentos - (Pirassununga - SP, 2002)

\begin{tabular}{|c|c|c|c|c|c|c|c|c|c|c|}
\hline & & & \multicolumn{8}{|c|}{ TRATAMENTO TS } \\
\hline \multirow{11}{*}{ 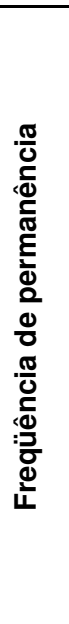 } & \multirow{11}{*}{ 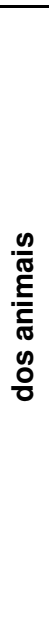 } & ao sol & $\mathrm{A} 1$ & $\mathrm{~A} 2$ & A3 & $\mathrm{A} 4$ & A5 & A6 & A7 & A8 \\
\hline & & sob a sombra & $\mathrm{A} 1$ & $\mathrm{~A} 2$ & A3 & A4 & A5 & A6 & A7 & A8 \\
\hline & & na água & $\mathrm{A} 1$ & $\mathrm{~A} 2$ & A3 & A4 & A5 & A6 & A7 & A8 \\
\hline & & & \multicolumn{8}{|c|}{ TRATAMENTO TSA } \\
\hline & & ao sol & $\mathrm{A} 1$ & $\mathrm{~A} 2$ & A3 & A4 & A5 & $\mathrm{A} 6$ & A7 & A8 \\
\hline & & sob a sombra & $\mathrm{A} 1$ & $\mathrm{~A} 2$ & A3 & A4 & A5 & A6 & A7 & A8 \\
\hline & & na água & $A 1^{a}$ & $\mathrm{~A} 2^{a}$ & $A 3^{a}$ & $\mathrm{~A} 4$ & $A 5^{a}$ & $A 6^{a}$ & $A 7^{a}$ & A8 \\
\hline & & & \multicolumn{8}{|c|}{ TRATAMENTO TA } \\
\hline & & ao sol & $\mathrm{A} 1$ & $\mathrm{~A} 2$ & A3 & $\mathrm{A} 4$ & A5 & $\mathrm{A} 6$ & A7 & A8 \\
\hline & & sob a sombra & $\mathrm{A} 1$ & $\mathrm{~A} 2$ & A3 & $A 4^{a}$ & A5 & A6 & A7 & A8 \\
\hline & & na água & $\mathrm{A} 1$ & $\mathrm{~A} 2$ & A3 & A4 & A5 & A6 & A7 & A8 \\
\hline
\end{tabular}


Tabela 11. - Correlações entre os surtos da posição "Ao Sol" para os diferentes animais e tratamentos - valores em vermelho são significativos $(p<0,05)$ - (Pirassununga - SP, 2002)

\begin{tabular}{|c|c|c|c|c|c|c|c|c|c|c|c|c|c|c|c|c|c|c|c|c|c|c|c|c|}
\hline & A1-TS & A2-TS & \begin{tabular}{|l|} 
A3-TS \\
\end{tabular} & A4-TS & A5-TS & A6-TS & A7-TS & \begin{tabular}{|l|} 
A8-TS \\
\end{tabular} & A1-TSA & A2-TSA & A3-TSA & A4-TSA & A5-TSA & A6-TSA & A7-TSA & A8-TSA & A1-TA & A2-TA & A3-TA & A4-TA & A5-TA & A6-TA & A7-TA & A8-TA \\
\hline A1-TS & & 0,51 & 0,57 & 0,72 & 0,72 & 0,72 & 0,64 & 0,53 & 0,31 & 0,31 & 0,16 & 0,26 & 0,24 & 0,37 & 0,33 & 0,27 & 0,02 & 0,06 & 0,12 & $-0,05$ & 0,02 & 0,05 & 0,20 & 0,04 \\
\hline A2-TS & & & 0,49 & 0,64 & 0,50 & 0,55 & 0,47 & 0,48 & 0,30 & 0,29 & 0,15 & 0,23 & 0,26 & 0,29 & 0,31 & 0,21 & $-0,05$ & $-0,06$ & 0,08 & $-0,11$ & 0,09 & $-0,04$ & $-0,04$ & $-0,03$ \\
\hline A3-TS & & & & 0,63 & 0,63 & 0,73 & 0,52 & 0,59 & 0,24 & 0,25 & 0,26 & 0,32 & 0,26 & 0,35 & 0,30 & 0,29 & 0,04 & 0,09 & 0,22 & 0,01 & 0,16 & 0,14 & 0,26 & 0,10 \\
\hline A4-TS & & & & & 0,71 & 0,71 & 0,56 & 0,70 & 0,19 & 0,18 & 0,14 & 0,22 & 0,19 & 0,29 & 0,22 & 0,18 & 0,03 & 0,17 & 0,17 & $-0,02$ & 0,20 & 0,11 & 0,16 & 0,13 \\
\hline A5-TS & & & & & & 0,83 & 0,77 & 0,60 & 0,19 & 0,22 & 0,19 & 0,22 & 0,23 & 0,34 & 0,27 & 0,22 & $-0,02$ & 0,13 & 0,13 & 0,03 & 0,11 & 0,06 & 0,21 & 0,04 \\
\hline A6-TS & & & & & & & 0,72 & 0,70 & 0,24 & 0,27 & 0,19 & 0,22 & 0,27 & 0,34 & 0,31 & 0,27 & $-0,02$ & 0,08 & 0,21 & $-0,02$ & 0,11 & 0,11 & 0,30 & 0,08 \\
\hline A7-TS & & & & & & & & 0,53 & 0,27 & 0,23 & 0,20 & 0,22 & 0,24 & 0,37 & 0,25 & 0,23 & $-0,01$ & 0,10 & 0,08 & 0,07 & 0,10 & 0,13 & 0,16 & 0,04 \\
\hline A8-TS & & & & & & & & & 0,09 & 0,09 & 0,02 & 0,04 & 0,10 & 0,19 & 0,11 & 0,05 & 0,02 & 0,09 & 0,19 & $-0,02$ & 0,21 & 0,13 & 0,20 & 0,12 \\
\hline A1-TSA & & & & & & & & & & 0,81 & 0,75 & 0,64 & 0,75 & 0,75 & 0,82 & 0,67 & 0,01 & $-0,07$ & 0,03 & $-0,07$ & 0,04 & 0,20 & 0,12 & 0,20 \\
\hline A2-TSA & & & & & & & & & & & 0,71 & 0,65 & 0,81 & 0,73 & 0,81 & 0,72 & $-0,01$ & $-0,03$ & 0,05 & $-0,12$ & $-0,01$ & 0,23 & 0,08 & 0,18 \\
\hline A3-TSA & & & & & & & & & & & & 0,70 & 0,76 & 0,67 & 0,68 & 0,78 & 0,01 & $-0,01$ & 0,03 & $-0,04$ & 0,04 & 0,18 & 0,09 & 0,23 \\
\hline A4-TSA & & & & & & & & & & & & & 0,63 & 0,73 & 0,61 & 0,62 & 0,02 & 0,05 & 0,12 & 0,04 & 0,09 & 0,22 & 0,10 & 0,33 \\
\hline A5-TSA & & & & & & & & & & & & & & 0,78 & 0,75 & 0,74 & $-0,09$ & $-0,01$ & 0,10 & $-0,07$ & $-0,03$ & 0,25 & 0,06 & 0,20 \\
\hline A6-TSA & & & & & & & & & & & & & & & 0,76 & 0,69 & $-0,08$ & $-0,05$ & 0,08 & $-0,05$ & $-0,01$ & 0,18 & 0,06 & 0,22 \\
\hline A7-TSA & & & & & & & & & & & & & & & & 0,70 & 0,07 & $-0,08$ & 0,06 & $-0,06$ & 0,07 & 0,28 & 0,16 & 0,20 \\
\hline A8-TSA & & & & & & & & & & & & & & & & & $-0,01$ & 0,01 & 0,02 & $-0,05$ & $-0,01$ & 0,23 & 0,08 & 0,18 \\
\hline A1-TA & & & & & & & & & & & & & & & & & & 0,42 & 0,38 & 0,47 & 0,58 & 0,60 & 0,53 & 0,41 \\
\hline A2-TA & & & & & & & & & & & & & & & & & & & 0,55 & 0,42 & 0,51 & 0,45 & 0,51 & 0,45 \\
\hline A3-TA & & & & & & & & & & & & & & & & & & & & 0,39 & 0,51 & 0,50 & 0,63 & 0,48 \\
\hline A4-TA & & & & & & & & & & & & & & & & & & & & & 0,53 & 0,43 & 0,45 & 0,35 \\
\hline A5-TA & & & & & & & & & & & & & & & & & & & & & & 0,54 & 0,50 & 0,51 \\
\hline A6-TA & & & & & & & & & & & & & & & & & & & & & & & 0,54 & 0,56 \\
\hline A7-TA & & & & & & & & & & & & & & & & & & & & & & & & 0,50 \\
\hline A8-TA & & & & & & & & & & & & & & & & & & & & & & & & \\
\hline
\end{tabular}


Tabela 13. - Correlações entre os surtos da posição "À Sombra" para os diferentes animais e tratamentos - valores em vermelho são significativos $(p<0,05)$ - (Pirassununga - SP, 2002)

\begin{tabular}{|c|c|c|c|c|c|c|c|c|c|c|c|c|c|c|c|c|c|c|c|c|c|c|c|c|}
\hline & A1-TS & A2-TS & A3-TS & A4-TS & A5-TS & A6-TS & A7-TS & A8-TS & A1-TSA & A2-TSA & A3-TSA & A4-TSA & A5-TSA & A6-TSA & A7-TSA & A8-TSA & A1-TA & A2-TA & A3-TA & A4-TA & A5-TA & A6-TA & A7-TA & \begin{tabular}{|l|} 
A8-TA \\
\end{tabular} \\
\hline A1-TS & & 0,51 & 0,57 & 0,72 & 0,72 & 0,72 & 0,64 & 0,53 & 0,31 & 0,33 & 0,23 & 0,30 & 0,25 & 0,33 & 0,32 & 0,26 & $-0,16$ & $-0,11$ & 0,00 & $-0,19$ & $-0,05$ & $-0,15$ & 0,01 & 0,02 \\
\hline A2-TS & & & 0,49 & 0,64 & 0,50 & 0,55 & 0,47 & 0,48 & 0,33 & 0,27 & 0,24 & 0,24 & 0,27 & 0,32 & 0,27 & 0,23 & $-0,10$ & $-0,05$ & 0,06 & $-0,07$ & 0,06 & $-0,08$ & 0,02 & 0,01 \\
\hline A3-TS & & & & 0,63 & 0,63 & 0,73 & 0,52 & 0,59 & 0,33 & 0,31 & 0,37 & 0,37 & 0,31 & 0,35 & 0,34 & 0,32 & $-0,05$ & $-0,01$ & 0,11 & $-0,03$ & 0,04 & 0,01 & 0,06 & 0,13 \\
\hline A4-TS & & & & & 0,71 & 0,71 & 0,56 & 0,70 & 0,26 & 0,24 & 0,22 & 0,22 & 0,24 & 0,30 & 0,26 & 0,21 & $-0,04$ & $-0,01$ & 0,06 & 0,02 & 0,09 & 0,00 & 0,07 & 0,09 \\
\hline A5-TS & & & & & & 0,83 & 0,77 & 0,60 & 0,34 & 0,33 & 0,31 & 0,31 & 0,33 & 0,39 & 0,35 & 0,30 & $-0,04$ & $-0,01$ & 0,06 & 0,02 & 0,09 & 0,00 & 0,07 & 0,09 \\
\hline A6-TS & & & & & & & 0,72 & 0,70 & 0,39 & 0,37 & 0,35 & 0,35 & 0,37 & 0,43 & 0,39 & 0,34 & $-0,11$ & $-0,07$ & 0,06 & $-0,08$ & 0,03 & $-0,06$ & 0,07 & 0,09 \\
\hline A7-TS & & & & & & & & 0,53 & 0,39 & 0,33 & 0,30 & 0,30 & 0,33 & 0,41 & 0,36 & 0,33 & $-0,04$ & 0,00 & 0,06 & 0,05 & 0,05 & 0,01 & 0,07 & 0,08 \\
\hline A8-TS & & & & & & & & & 0,34 & 0,32 & 0,29 & 0,25 & 0,32 & 0,36 & 0,35 & 0,24 & $-0,01$ & 0,03 & 0,14 & $-0,01$ & 0,13 & 0,04 & 0,15 & 0,16 \\
\hline A1-TSA & & & & & & & & & & 0,90 & 0,82 & 0,79 & 0,87 & 0,87 & 0,92 & 0,74 & $-0,01$ & $-0,09$ & 0,10 & 0,03 & 0,05 & 0,12 & 0,08 & 0,19 \\
\hline A2-TSA & & & & & & & & & & & 0,79 & 0,85 & 0,84 & 0,88 & 0,89 & 0,74 & 0,00 & $-0,07$ & 0,07 & $-0,04$ & 0,02 & 0,09 & 0,04 & 0,15 \\
\hline A3-TSA & & & & & & & & & & & & 0,80 & 0,85 & 0,80 & 0,81 & 0,82 & 0,01 & $-0,05$ & 0,09 & 0,05 & 0,08 & 0,15 & 0,11 & 0,22 \\
\hline A4-TSA & & & & & & & & & & & & & 0,76 & 0,84 & 0,78 & 0,69 & 0,01 & $-0,05$ & 0,09 & $-0,03$ & 0,04 & 0,11 & 0,06 & 0,17 \\
\hline A5-TSA & & & & & & & & & & & & & & 0,88 & 0,82 & 0,74 & 0,00 & $-0,07$ & 0,11 & 0,03 & 0,06 & 0,13 & 0,09 & 0,20 \\
\hline A6-TSA & & & & & & & & & & & & & & & 0,89 & 0,76 & $-0,05$ & $-0,13$ & 0,06 & 0,00 & 0,00 & 0,08 & 0,04 & 0,16 \\
\hline A7-TSA & & & & & & & & & & & & & & & & 0,73 & $-0,02$ & $-0,09$ & 0,10 & 0,02 & 0,04 & 0,11 & 0,07 & 0,18 \\
\hline A8-TSA & & & & & & & & & & & & & & & & & $-0,08$ & $-0,10$ & $-0,05$ & $-0,16$ & $-0,08$ & 0,02 & 0,02 & 0,07 \\
\hline A1-TA & & & & & & & & & & & & & & & & & & 0,45 & 0,52 & 0,57 & 0,59 & 0,79 & 0,50 & 0,52 \\
\hline A2-TA & & & & & & & & & & & & & & & & & & & 0,45 & 0,31 & 0,76 & 0,37 & 0,63 & 0,38 \\
\hline A3-TA & & & & & & & & & & & & & & & & & & & & 0,31 & 0,63 & 0,70 & 0,63 & 0,67 \\
\hline A4-TA & & & & & & & & & & & & & & & & & & & & & 0,54 & 0,59 & 0,30 & 0,24 \\
\hline A5-TA & & & & & & & & & & & & & & & & & & & & & & 0,61 & 0,67 & 0,59 \\
\hline A6-TA & & & & & & & & & & & & & & & & & & & & & & & 0,54 & 0,65 \\
\hline A7-TA & & & & & & & & & & & & & & & & & & & & & & & & 0,58 \\
\hline A8-TA & & & & & & & & & & & & & & & & & & & & & & & & \\
\hline
\end{tabular}


Tabela 14. - Correlações entre os surtos da posição "Na Água" para os diferentes animais e tratamentos - valores em vermelho são significativos $(p<0,05)$ - (Pirassununga - SP, 2002)

\begin{tabular}{|c|c|c|c|c|c|c|c|c|c|c|c|c|c|c|c|c|c|c|c|c|c|c|c|c|}
\hline & A1-TS & A2-TS & A3-TS & A4-TS & A5-TS & A6-TS & A7-TS & A8-TS & A1-TSA & A2-TSA & A3-TSA & A4-TSA & A5-TSA & A6-TSA & A7-TSA & A8-TSA & A1-TA & A2-TA & A3-TA & A4-TA & A5-TA & A6-TA & A7-TA & A8-TA \\
\hline \multicolumn{25}{|l|}{ A1-TS } \\
\hline \multicolumn{25}{|l|}{ A2-TS } \\
\hline \multicolumn{25}{|l|}{ A3-TS } \\
\hline \multicolumn{25}{|l|}{ A4-TS } \\
\hline \multicolumn{25}{|l|}{ A5-TS } \\
\hline \multicolumn{25}{|l|}{ A6-TS } \\
\hline \multicolumn{25}{|l|}{ A7-TS } \\
\hline \multicolumn{25}{|l|}{ A8-TS } \\
\hline A1-TSA & & & & & & & & & & 0,54 & 0,49 & 0,55 & 0,62 & 0,60 & 0,57 & 0,26 & 0,25 & 0,23 & 0,19 & 0,19 & 0,23 & 0,15 & 0,17 & 0,24 \\
\hline A2-TSA & & & & & & & & & & & 0,42 & 0,38 & 0,72 & 0,42 & 0,66 & 0,42 & 0,17 & 0,20 & 0,18 & 0,09 & 0,20 & 0,15 & 0,08 & 0,16 \\
\hline A3-TSA & & & & & & & & & & & & 0,50 & 0,37 & 0,40 & 0,34 & 0,40 & 0,22 & 0,26 & 0,16 & 0,23 & 0,33 & 0,12 & 0,21 & 0,21 \\
\hline A4-TSA & & & & & & & & & & & & & 0,44 & 0,68 & 0,59 & 0,33 & 0,14 & 0,34 & 0,24 & 0,30 & 0,34 & 0,18 & 0,21 & 0,27 \\
\hline A5-TSA & & & & & & & & & & & & & & 0,52 & 0,60 & 0,37 & 0,13 & 0,24 & 0,21 & 0,11 & 0,16 & 0,18 & 0,12 & 0,20 \\
\hline A6-TSA & & & & & & & & & & & & & & & 0,60 & 0,40 & 0,16 & 0,20 & 0,16 & 0,17 & 0,13 & 0,12 & 0,14 & 0,21 \\
\hline A7-TSA & & & & & & & & & & & & & & & & 0,47 & 0,24 & 0,20 & 0,24 & 0,13 & 0,27 & 0,13 & 0,15 & 0,15 \\
\hline A8-TSA & & & & & & & & & & & & & & & & & 0,16 & 0,26 & 0,16 & 0,04 & 0,13 & 0,12 & 0,14 & 0,15 \\
\hline A1-TA & & & & & & & & & & & & & & & & & & 0,35 & 0,40 & 0,63 & 0,53 & 0,62 & 0,51 & 0,49 \\
\hline A2-TA & & & & & & & & & & & & & & & & & & & 0,58 & 0,44 & 0,60 & 0,51 & 0,56 & 0,50 \\
\hline A3-TA & & & & & & & & & & & & & & & & & & & & 0,55 & 0,51 & 0,57 & 0,59 & 0,54 \\
\hline A4-TA & & & & & & & & & & & & & & & & & & & & & 0,59 & 0,61 & 0,56 & 0,52 \\
\hline A5-TA & & & & & & & & & & & & & & & & & & & & & & 0,58 & 0,63 & 0,57 \\
\hline A6-TA & & & & & & & & & & & & & & & & & & & & & & & 0,64 & 0,69 \\
\hline A7-TA & & & & & & & & & & & & & & & & & & & & & & & & 0,58 \\
\hline A8-TA & & & & & & & & & & & & & & & & & & & & & & & & \\
\hline
\end{tabular}


Tabela 15. - Média de surtos dos animais nos diferentes tratamentos - (Pirassununga - SP, 2002)

\begin{tabular}{|c|c|c|c|c|c|c|c|c|c|c|c|}
\hline & 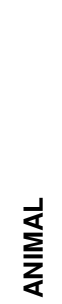 & $\begin{array}{l}\overrightarrow{1} \\
\text { O } \\
\text { O }\end{array}$ & 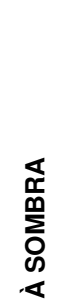 & 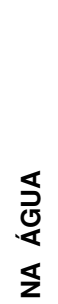 & 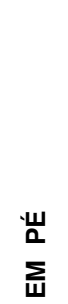 & $\begin{array}{l}\text { O } \\
\text { 它 } \\
\text { 岁 }\end{array}$ & 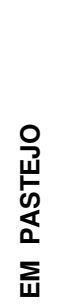 & 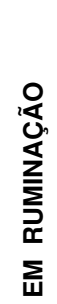 & 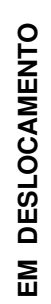 & $\begin{array}{l}\text { 응 } \\
\text { 언 }\end{array}$ & 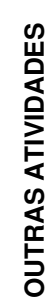 \\
\hline \multirow{8}{*}{ 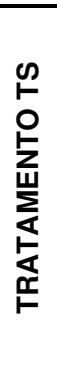 } & A1 & 29 & 94 & 0 & 72 & 51 & 27 & 16 & 7 & 48 & 25 \\
\hline & A2 & 37 & 86 & 0 & 68 & 55 & 32 & 12 & 5 & 58 & 16 \\
\hline & A3 & 28 & 95 & 0 & 58 & 65 & 29 & 18 & 3 & 58 & 15 \\
\hline & A4 & 21 & 102 & 0 & 64 & 59 & 25 & 11 & 3 & 71 & 13 \\
\hline & A5 & 21 & 102 & 0 & 54 & 69 & 24 & 17 & 4 & 63 & 15 \\
\hline & A6 & 21 & 102 & 0 & 58 & 65 & 24 & 19 & 4 & 54 & 22 \\
\hline & A7 & 29 & 94 & 0 & 68 & 55 & 31 & 7 & 3 & 61 & 21 \\
\hline & A8 & 33 & 90 & 0 & 68 & 55 & 40 & 24 & 3 & 42 & 14 \\
\hline \multirow{8}{*}{ 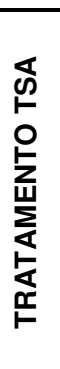 } & A1 & 40 & 64 & 10 & 76 & 38 & 28 & 16 & 4 & 41 & 25 \\
\hline & A2 & 47 & 62 & 5 & 67 & 47 & 31 & 16 & 5 & 41 & 21 \\
\hline & A3 & 46 & 59 & 9 & 69 & 45 & 33 & 9 & 3 & 47 & 22 \\
\hline & A4 & 37 & 59 & 18 & 77 & 37 & 25 & 16 & 5 & 40 & 28 \\
\hline & A5 & 46 & 62 & 6 & 65 & 49 & 27 & 19 & 3 & 44 & 21 \\
\hline & A6 & 35 & 70 & 9 & 66 & 48 & 25 & 17 & 3 & 49 & 20 \\
\hline & A7 & 42 & 65 & 7 & 72 & 42 & 31 & 16 & 5 & 41 & 21 \\
\hline & A8 & 47 & 58 & 9 & 74 & 40 & 33 & 12 & 3 & 39 & 27 \\
\hline \multirow{8}{*}{ 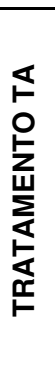 } & A1 & 61 & 14 & 48 & 98 & 25 & 21 & 17 & 0 & 62 & 23 \\
\hline & A2 & 65 & 17 & 41 & 97 & 26 & 33 & 16 & 0 & 54 & 20 \\
\hline & A3 & 59 & 17 & 47 & 100 & 23 & 28 & 24 & 2 & 45 & 24 \\
\hline & A4 & 43 & 7 & 73 & 111 & 12 & 20 & 22 & 1 & 52 & 28 \\
\hline & A5 & 61 & 21 & 41 & 95 & 28 & 31 & 19 & 0 & 50 & 23 \\
\hline & A6 & 50 & 18 & 55 & 102 & 21 & 20 & 32 & 1 & 45 & 25 \\
\hline & A7 & 54 & 18 & 51 & 101 & 22 & 30 & 28 & 2 & 42 & 21 \\
\hline & A8 & 59 & 14 & 50 & 99 & 24 & 25 & 26 & 1 & 44 & 27 \\
\hline
\end{tabular}




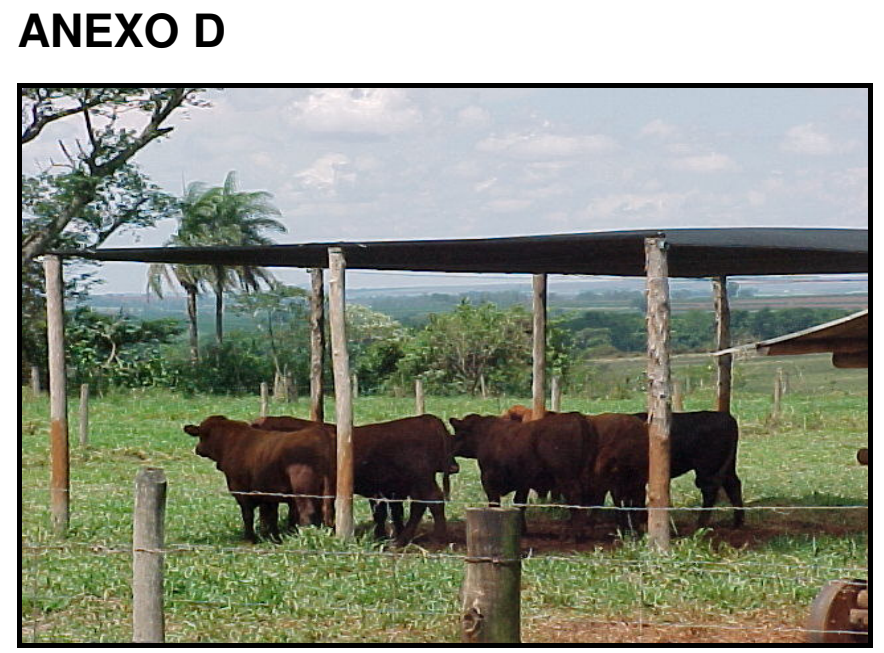

Figura A - Animais utilizando o recurso da sombra artificial

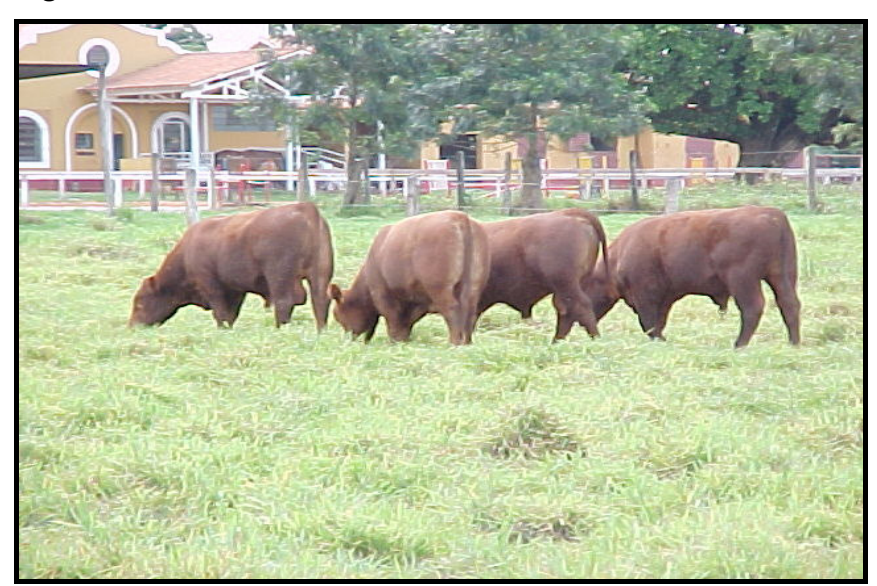

Figura B - Animais em pastejo matutino

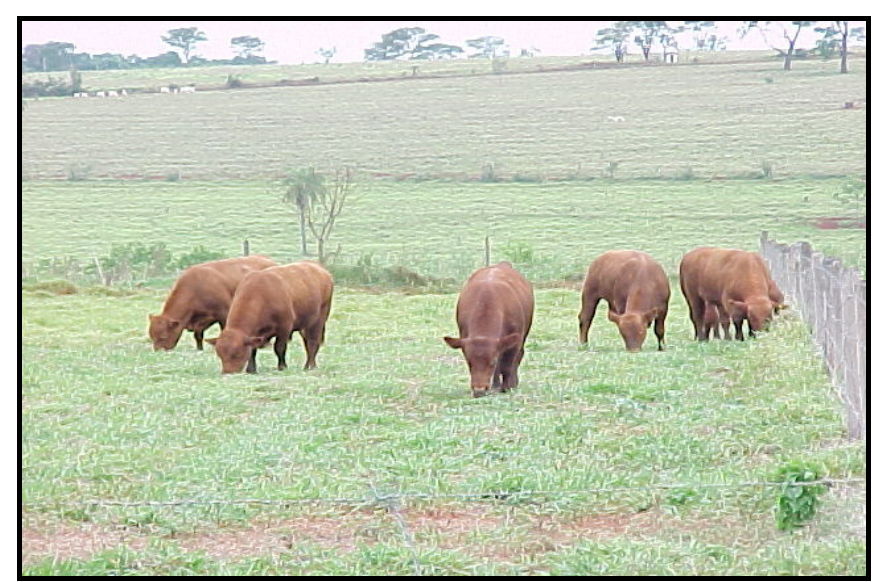

Figura C - Animais em pastejo vespertino

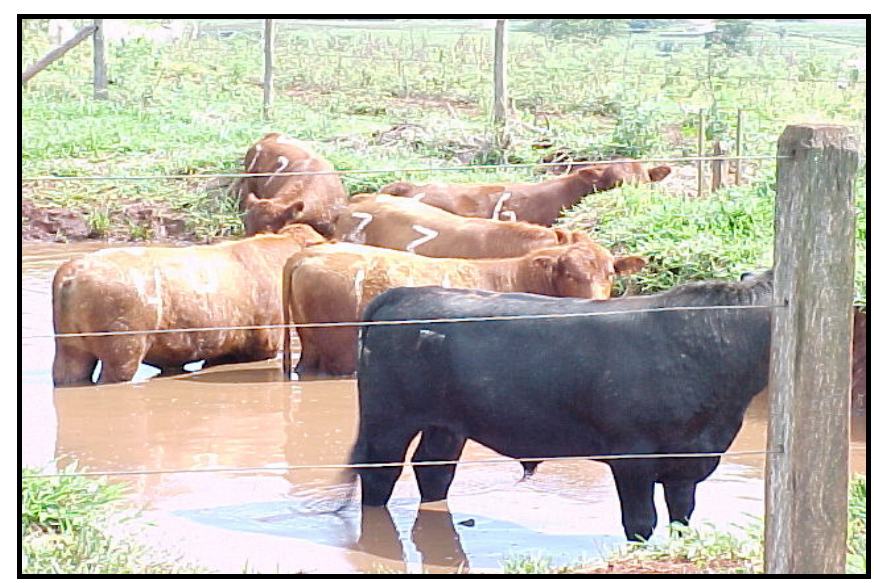

Figura D - Animais utilizando o recurso da água para imersão 


\section{REFERÊNCIAS BIBLIOGRÁFICAS}

ABLAS, D. S. Comportamentos de búfalos a pasto frente à disponibilidade de sombra e água para imersão no Sudeste do Brasil. 2002. 70 p.

Dissertação (Mestrado) - Faculdade de Zootecnia e Engenharia de Alimentos, Universidade de São Paulo, Pirassununga.

ALBRIGHT, J. L.; ALLISTON, C. W. Effects of varying the environment upon performance of dairy cattle. J. Anim. Sci., n. 32, p. 566-577, 1972.

APPLEBY, M. C. Can we extrapolate from intensive to extensive conditions? Applied Anim. Behaviour Sci., v. 49, p. 23-27, 1996.

APPLEBY, M. C.; HUGHES, B. O. Animal welfare. Wallingford: CAB International, 1997. $316 \mathrm{p}$.

BACCARI JÚNIOR, F. Manejo ambiental da vaca leiteira em climas quentes. Londrina: UEL, 2001. 142 p.

BACCARI JÚNIOR, F.; FRÉ, C. A.; ASSIS, R. S.; GARCIA, E. A. Valores fisiológicos da temperatura retal em vacas holandesas em clima tropical de altitude. In: ENCONTRO DE PESQUISAS VETERINÁRIAS, 1., 1984, Londrina. Anais... p. 15-22.

BACCARI JÚNIOR, F.; GAYÃO, A. L. B.; AGUIAR, I. S. Índice de circulação térmica em garrotes Nelore e Chianina em condições de termoneutralidade. In: REUNIÃO ANUAL DA SOCIEDADE BRASILEIRA DE ZOOTECNIA, 29., 1992, Lavras. Anais... Lavras: SBZ, 1992. p. 15.

BACCARI JÚNIOR, F.; MACHADO, M. A.; MARÇAL, W. S.; LIBONI, M.; FELIPETTO, L. Heat tolerance and growth rate of young buffalo bulls. In: CONGRESSO BRASILEIRO DE BIOMETEOROLOGIA, 2., 1998. Goiânia. Anais... p. 349-353.

BARNETT, J. L.; HEMSWORTH, P. H. The validity of physiological and behavioural measures of animal welfare. Appl. Anim. Behav. Sci. v. 9, p. 177187, 1990. 
BAXTER, M. R. Needs: behavioural or psychological? Appl. Anim. Behav. Sci. v. 19, p. $345-348,1988$.

BERMAN, A.; FOLMAN, Y.; KAIM, M.; MAMEN, M.; HERZ, Z.; WOLFENSON, D.; ARIELI, A.; GRABER, Y. Upper critical temperatures and forced ventilation effects for high-yielding dairy cows in a subtropical climate. J. Dairy Sci., v. 68, p. 1488-1495, 1985.

BIANCA, W. Thermoregulation. In: HAFEZ, E. S. E. Adaptación de los animales domesticos. Barcelona: Labor,1973. p. 97-118.

BLACKSHAW, J. D.; BLACKSHAW, A. W. Heat stress in cattle and the effect of shade on production and behaviour: a review. Australian J. of Experim. Agri., v. 34, p. 285-295, 1994.

BROOM, D. M. Animal welfare: concepts and measurement. J. Anim. Sci., v. 69, p. 4167-4175, 1991.

BROOM, D. M. The concept of stress and welfare. Rec. Méd. Vét., v. 164, n. 10, p. 715-722, 1988.

BROOM, D. M. Welfare evaluation. Applied Anim. Behaviour Sci., v. 54, p. 21-23, 1997.

BROOM, D. M.; JOHNSON, K. G. Stress and animal welfare. London: Chapman \& Hall, 1993. 211 p.

BUCKLIN, R. A.; BRAY, D. R. The american experience in dairy management in warm and hot climates. In: SIMPÓSIO BRASILEIRO DE AMBIÊNCIA NA PRODUÇÃO DE LEITE, 1., 1998, Piracicaba. Anais... Piracicaba: FEALQ, 1998. p. 156-174.

BUFFINGTON, D. E.; COLLAZO-AROCHO, A.; CANTON, G. H.; PITT, D.; THATCHER, W. W.; COLLIER, R. J. Black globe-humidity index (BGHI) as confort equation for dairy cows. Trans ASAE (Am.Soc.Agric.Eng.), p. 711714, 1981.

CAMBRIDGE DICTIONARIES. Disponível em:<http://dictionary.cambridge.org> Acesso em: 28 mar. 2003.

CARTHY, J. D.; HOWSE, P. E. Comportamento animal, v. 14, p. 1-8, 1980.

CHEVILLON, P. O bem estar dos suínos durante o pré-abate e o atordoamento. Conf. Virtual sobre Qualidade de Carne Suína, 1. Disponível em: <http://www.embrapa.gov.br>. Acesso em: 28 mar. 2003.

CURTIS, S. E.; HOUPT, K. A. Animal ethology: its emergence in animal science, J. Anim. Sci., v. 57, p. 234-247, 1983. 
FELIUS, M. Genus Bos: cattle breeds of the world. [S.I.]: MSD AGVET, 1985. p. 4-5.

FERREIRA, Aurélio Buarque de Holanda. Dicionário aurelio da língua portuguesa. São Paulo: Nova Fronteira, 1995. 687 p.

FINCH, V. A. Heat as a stress factor in herbivores under tropical conditions. In: GILCHRIST, F. M. C.; MACKIE, R. I. Herbivore nutrition in the subtropics and tropics. Graighall: The Science Press, 1984. p. 89-105.

FINDLAY, J. D. The effects of temperature, humidithy, air movement and solar radiation on the behaviour and physiology of cattle and other farm animals. The Hannah Dairy Research Institute, p. 8-21, 47-90, 145-162, 1950.

FORD, B. D. Swamp buffaloes in large scale ranching systems. In: TULLOH, N. M.; HOLMES, J. H. G. Buffalo production. Amsterdam: Elsevier, 1992. p. 465481.

FRASER, A. Beef cattle husbandry. [S.I.]: Crosby Lockwood \& Son, 1959. p. 62-79.

FRASER, A. F.; BROOM, D. M. Farm animal behaviour and welfare, 3. ed. London: Baillière Tindall, 1997. 437 p.

FRASER, A. F.; BROOM, D. M. Farm animal behaviour and welfare. 3. ed. London: Baillière Tindall, 1990. 437 p.

FRASER, D. Animal ethics and animal welfare science: bridging the two cultures. Applied Anim. Behaviour Sci., v. 65, p. 171-189, 1999.

FRASER, D. Farm animal welfare: social, bioethical, and research issues, Bernard E. Rollin. lowa State University Press. Applied Anim. Behaviour Sci., v. 53, p. 225-228, 1997.

FRASER, D., RITCHIE, J. S. D.; FRASER, A. F. The term "stress" in a veterinary context. Br. Vet. J., v. 131, p. 653-662, 1975.

GEBREMEDHIN, K. G. Heat exchange between livestock and the environment. In: YOUSEF, M. K. (Ed.). Stress physiology in livestock, v. 1, p. 15-33, 1985.

HAFEZ, E. S. E. Adaptacion de los animals domesticos. Barcelona: Labor, 1973.

HANSEN, P. J.; ARÉCHIGA, C. F. Strategies for managing reproduction in the heat-stressed dairy cow. J. Anim. Sci., v. 77, p. 36-50, 1999.

HEAD, H. H. Management of dairy cattle in tropical and subtropical environments. CONGRESSO BRASILEIRO DE BIOMETEOROLOGIA, 1., 1995, Jaboticabal. Anais... 
HODGSON, J. Grazing management: science into practice. Longman: Scientific \& Technical, 1990. p. 1-5, 25-37, 121-133.

HUNTINGFORD, F. A. The study of animal behavior. London: Chapman \& Hall, 1984. p. $350-356$.

IGONO, M. O.; BJOTVET, G.; SANFORD-CRANE, H. T. Environmental profile and critical temperature effects on milk production of Holstein cows in desert climate. Int. J. Biometeorol, v. 36, p. 77-87, 1992.

JACOBSEN, K. L. The well-being of dairy cows in hot and humid climates. II. Reducing stress. Compendium of Continues Education in Practical Veterinary, v. 18, p. 242-254, 1996.

LAWRENCE, A. B.; APPLEBY, M. C. Welfare of extensively farmed animals: principles and practice. Applied Anim. Behaviour Sci., v. 49, p. 1-8, 1996.

LEE, D. H. K. Tolerancia de los animales domesticos al calor. [S.I.]: FAO, 1954. p.104-109.

LEHNER, P. N. Handbook of ethological methods. Cambridge-UK: Cambridge, 1996.

MARAI, I. F. M.; HABEEB, A. A. M. Adaptability of Bos taurus cattle under hot arid conditions. Annals of Arid Zone, v. 37, n. 3, p. 253-281, 1998.

MARTELLO, L.S. Diferentes recursos de climatização e sua influência na produção de leite, na termorregulação dos animais e no investimento das instalações. Pirassununga, 2002. 67 p. Dissertação (Mestrado) - Faculdade de Zootecnia e Engenharia de Alimentos, Universidade de São Paulo.

MARTIN, P.; BATESON, P. Measuring behavior: an introductory guide. Cambridge-UK: Cambridge University Press, 1986.

MAYR, E. Behavior programs and evolutionary strategies. American Scientist, v. 62, p. 650-659, 1974.

McFARLAND, D. Animal behavior: psychobiology, ethology and evolution, 3. ed. [S.I.]: Prentice Hall, 1999. p. 259-307.

MERRIAM-WEBSTER DICTIONARY. Disponível em: <http://www.m-w.com>. Acesso em: 28 mar. 2003.

NÃ̃̃S, I. A. Princípios de conforto térmico na produção animal. São Paulo: Ícone, 1989. $183 \mathrm{p}$.

OLIVEIRA, J. B.; PRADO, H. Levantamento pedológico do Estado de São Paulo. Bol. Técn. do Instituto Agronômico de Campinas, n. 98, 1984. 188 p. 
PARANHOS DA COSTA, M. J. R. Ambiência na produção de bovinos de corte a pasto. Anais de Etologia, 2000.

PARANHOS DA COSTA, M. J. R.; CROMBERG, V. U. Alguns aspectos a serem considerados para melhorar o bem-estar de animais em sistemas de pastejo rotacionado. In: SIMPÓSIO SOBRE MANEJO DE PASTAGENS, 14., 1997, Anais... p. 273-283.

POPPI, D.P; HUGHES, T.P.; L'HUILLIER, P.J. Intake of pastures by grazing ruminants. In: NICOL, A.M. Feeding livestock on pasture. Hamilton: New Zealand Society of Animal Production, 1987. p. 55-64.

ROBERTSHAW, D. The environmental physiology of animal production. In: CLARK, J. A. Environmental aspects of housing for animal production. London: Butterworth, 1981. p. 3-17.

SANTIAGO, A. A. Os cruzamentos na pecuária bovina. [S.I.]: IZ, 1975. p. 268-271.

SANTOS, R. Os cruzamentos na pecuária moderna. [S.I.]: Editora Agropecuária Tropical, 1999.

SEAMER, J. H. Human stewardship and animal welfare. Applied Anim.

Behav. Sci., v. 59, p. 201-205, 1998.

SELYE, H. A syndrome produced by diverse noxious agents. Nature, p. 138, 1936.

SILANIKOVE, N. Effects of heat stress on the welfare of extensively managed domestic ruminants. Livestock Prod. Sci., v. 67, p. 1-18, 2000.

SILANIKOVE, N. Effects of water scarcity and hot environment on appetite and digestion in ruminants: a review. Livestock Prod. Sci., v. 30, p. 175-194, 1992.

SILVA, R. G. Introdução à bioclimatologia animal. São Paulo: Nobel, 2000. 286p.

THATCHER, W.W., GWAZDAUSKAS, F.C., WILCOX, C.J., TOMS, T., HEAD, H.H., BUFFINGTON, D.E., FREDERKSSON, W.B. Milking performance and reproductive efficiency of dairy cows in an environmentally controlled structure. J. Dairy Sci., v. 57, p. 304-307, 1974.

THATCHER, W.W.; COLLIER, R.J. Effect of heat on animal productivity. In: RECHEIGL, M. (ed). CRC Handbook of Agricultural Productivity, v. 2, p. 77$105,1982$.

TITTO, E.A.L. Clima: Influência na produção de leite. Ambiência na produção de leite em clima quente, Piracicaba: FEALQ, 1998. 
TITTO, E.A.L.; RUSSO, H.G.; LIMA, C.G. Efeito do banho de água sobre o conforto térmico de bubalinos. In: CONGRESSO DE ZOOTECNIA, 6, 1996. Actas... Évora, 1996. v. 1, p. 15-18.

TITTO, E.A.L.; VELLOSO, L.; ZANETTI, M.A.; CRESTA, A.; TOLEDO, L.R.A.; MARTINS, J.H. Teste de tolerância ao calor em novilhos nelore e marchigiana. Ver. Port. Zootec., v. 5 (1), p. 67-70, 1998.

VOISIN, A. Produtividade do pasto, São Paulo: Editora Mestre Jou, 517p.

VON BOREL, E. Neuroendocrine integration of stress and significance of stress for the performance of farm animals. Appl. Anim. Behav. Sci. v. 44, p. 219227, 1995.

WEARY, D.M.; APPLEBY, M.C.; FRASER, D. Responses of piglets to early separation from the sow. Appl. Anim. Behav. Sci. v. 63 (2), p. 289-300, 2000.

WEBSTER, A.J.F. Farm animal welfare: the five freedoms and the free market. Vet. J., v. 161, n. 3, p. 229-237, 2001.

WEBSTER, A.J.F. Meat and right: farming as if the animal mattered. Can. Vet. J., v. 28, n. 8, 1987.

WILLIANS, D.W. Produção de gado de corte no sul dos E.U.A., USAID, p. 86-87, 1967, 447p.

YOUSEF, M.K. Stress physiology in livestock: basic principles, v. 1. Boca Raton: CRC Press, 1985. 3v. 